\title{
WestVirginiaUniversity
}

THE RESEARCH REPOSITORY @ WVU

Graduate Theses, Dissertations, and Problem Reports

2003

\section{Comparison of concentrations in the breathing zone}

\author{
Santosh Raghavendra Kulkarni \\ West Virginia University
}

Follow this and additional works at: https://researchrepository.wvu.edu/etd

\section{Recommended Citation}

Kulkarni, Santosh Raghavendra, "Comparison of concentrations in the breathing zone" (2003). Graduate Theses, Dissertations, and Problem Reports. 1326.

https://researchrepository.wvu.edu/etd/1326

This Thesis is protected by copyright and/or related rights. It has been brought to you by the The Research Repository @ WVU with permission from the rights-holder(s). You are free to use this Thesis in any way that is permitted by the copyright and related rights legislation that applies to your use. For other uses you must obtain permission from the rights-holder(s) directly, unless additional rights are indicated by a Creative Commons license in the record and/ or on the work itself. This Thesis has been accepted for inclusion in WVU Graduate Theses, Dissertations, and Problem Reports collection by an authorized administrator of The Research Repository @ WVU. For more information, please contact researchrepository@mail.wvu.edu. 


\title{
"Comparison of Concentrations in the Breathing Zone"
}

\author{
Santosh Kulkarni \\ Thesis submitted to the \\ College of Engineering and Mineral Resources \\ at West Virginia University \\ in partial fulfillment of the requirements \\ for the degree of \\ Master of Science \\ in
}

Occupational Hygiene and Occupational Safety

Steven E.Guffey, Ph.D., Chair

Warren Myers, Ph.D.

Christopher Coffey, Ph.D.

Department of Industrial and Management Systems Engineering

Morgantown, West Virginia

2003

Keywords: Exposure assessment, Human exposure, Ventilation, Breathing zone 


\title{
ABSTRACT \\ "Comparison of Concentrations in the Breathing zone"
}

\begin{abstract}
Santosh Kulkarni
The concentrations in the "breathing zone" were analyzed on three human subjects in simulating work conditions. The experiments were carried out in a wind tunnel having 40'x12'x9' dimensions. Ethanol vapor mixed with nitrogen was used as a tracer gas. Samples were taken at the forehead, adjacent to the nose (nose), the mouth, neck, chest, right lapel, left lapel. Nose was sampled at 1liter per minute $(\mathrm{lpm})$ and $0.15 \mathrm{lpm}$ at different times, while the others were sampled at $0.15 \mathrm{lpm}$ at two different wind tunnel velocities. The source was released at naval height for each subject.

It was concluded that wind tunnel velocities, and ratios of the chest and the shoulder dimensions played a significant role in the concentration among the sampling sites. Sampling rate affected only the concentration at the nose and at no other sampling site. Further studies would be useful in determining the impact of wind tunnel velocities and the selection of human subjects with a variety of anthropometrical dimensions and clothing use.
\end{abstract}




\section{ACKNOWLEDGEMENTS}

This work has been supported by the Industrial Management and Systems Engineering

Department, WVU and by the National Institute for Occupational Health and Safety grant (1RO1 OHO4081-01).

I take this opportunity to thank everyone involved in this study. First, I would like to thank Dr.

Steven Guffey, who not only guided me in each step of this study but also has been a guide and mentor during my stay at the WVU. I would thank Dr. Warren Myers and Dr. Christopher Coffey for their continued support and advice and for serving on my committee. I give special thanks to Mr. Dalton for his support and advice in every aspect of this study.

I would also thank Dr. Lee and all my friends involved in this study, Sumeeth, Amit, Ahmed, and Walid. All helped me to complete my study.

The blessings of God, my late father Mr. Ragahavendra V. Kulkarni, my mother Mrs. Geetanjali Kulkarni, my brother Vithal and my sister-in-law Padmaja were always on my mind without them I would never have been able to achieve success in life.

Special thanks to all the human subjects who participated in the study. I thank all my friends and all those involved directly or indirectly with this study.

Mr. Madhav Kolgaonkar and Mr. Sunil Kulkarni supported and guided me through tough phases in my life and I would like to acknowledge their help and blessings.

This thesis is dedicated to a special person who had a great impact in shaping my life, who loved me, and helped to achieve my dreams. 


\section{TABLE OF CONTENTS}

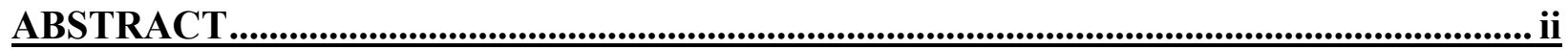

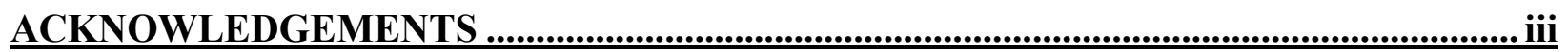

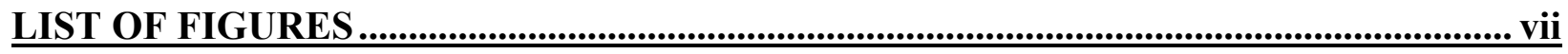

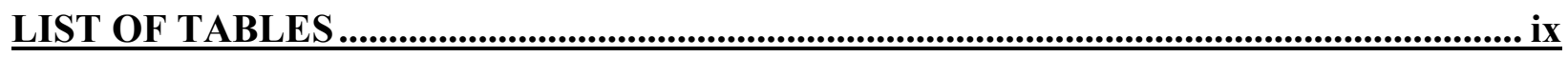

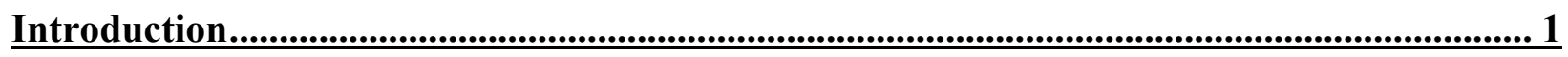

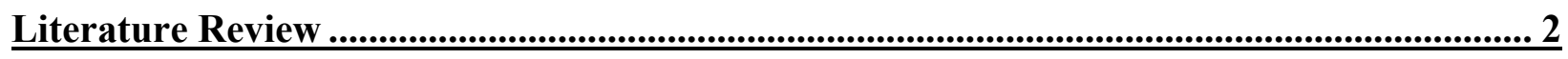

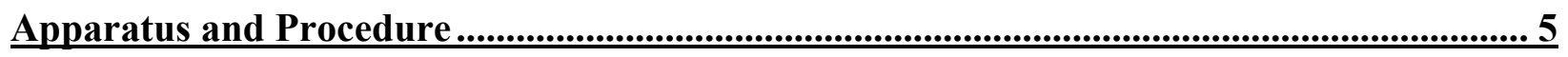

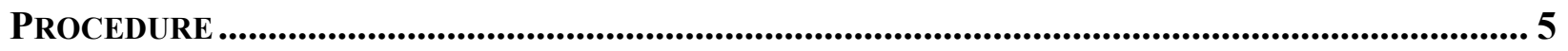

A) PREPARATION SAMPLING SYSTEM PRIOR TO EXPERIMENT RUNS........................................... 6

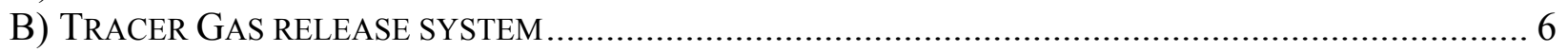

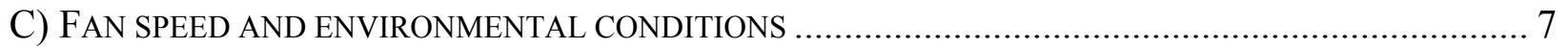

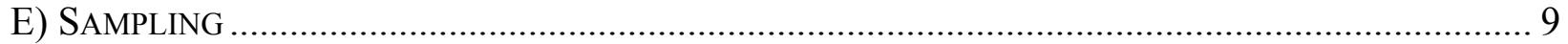

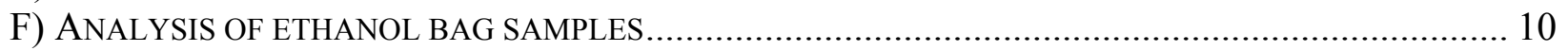

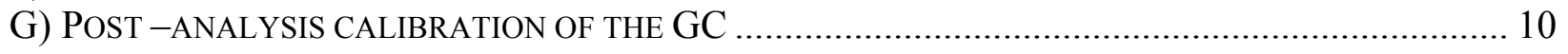

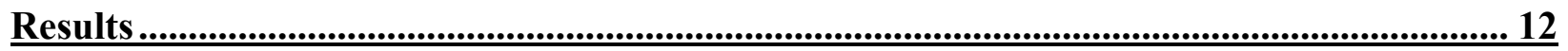

COMPARISON OF CONCENTRATIONS AT DIFFERENT LOCATIONS............................................ 12

EFFECTS OF SAMPLING RATE AT THE NOSE ON CONCENTRATIONS AND RATIOS OF

CONCENTRATIONS ..................................................................................................... 13

EFFECTS OF CROSS DRAFT VELOCITY ON CONCENTRATIONS AND RATIOS OF CONCENTRATIONS

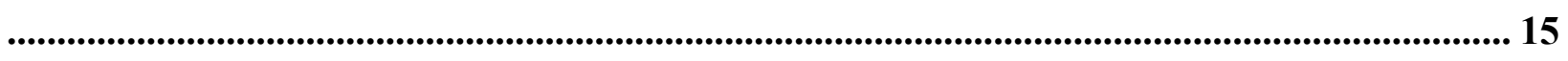

EFFECTS OF SUBJECTS ON CONCENTRATIONS AND RATIOS OF CONCENTRATIONS .................... 18

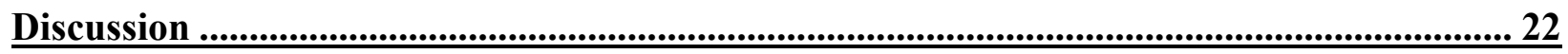

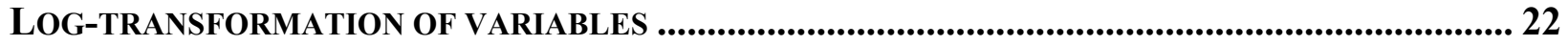

EFFECTS OF INDEPENDENT VARIABLES ON CONCENTRATION VALUES AND RATIOS OF

CONCENTRATIONS................................................................................................................2 26

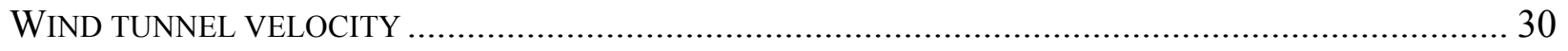

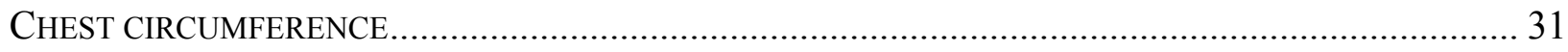

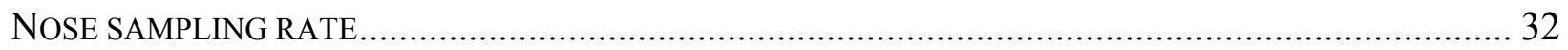

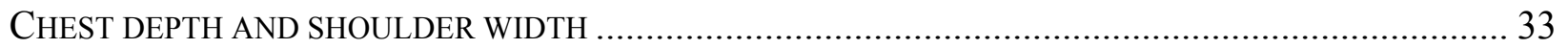




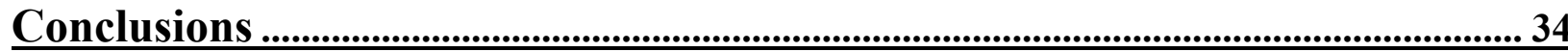

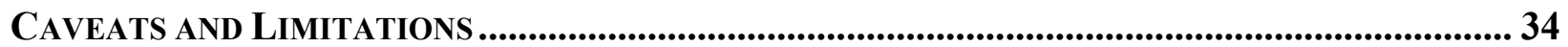

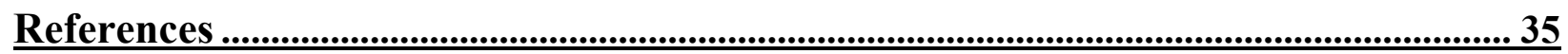

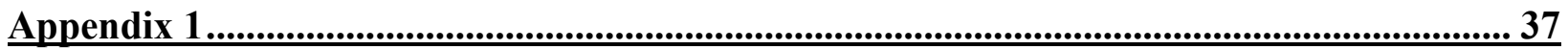

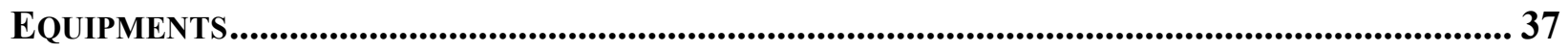

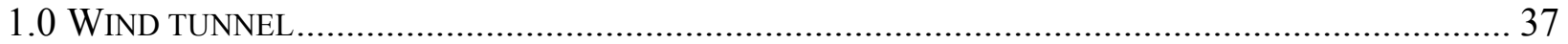

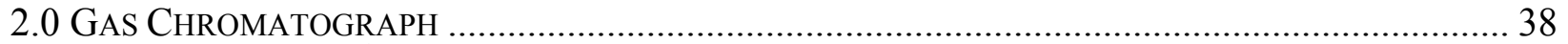

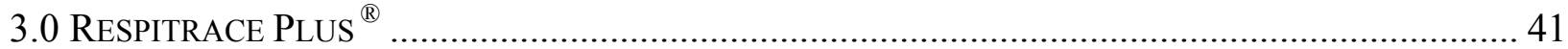

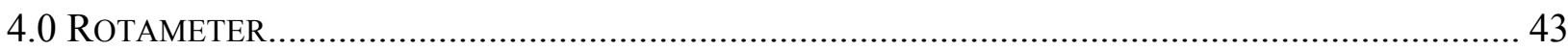

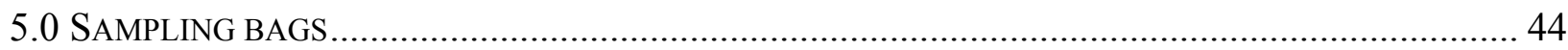

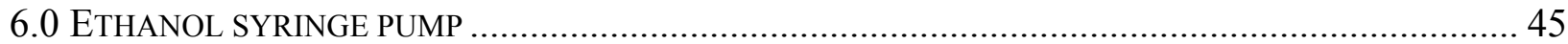

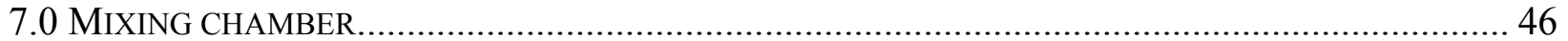

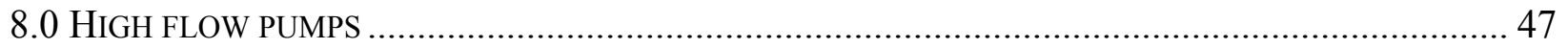

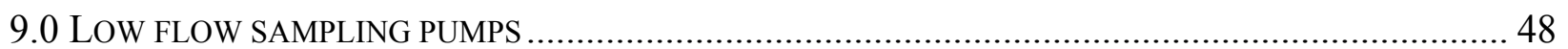

10.0 LARGE VOLUME MANUAL SYRINGE (CALIBRATION SYRINGE) ......................................... 49

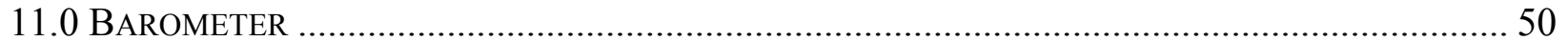

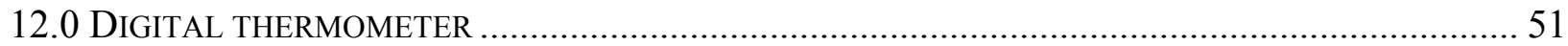

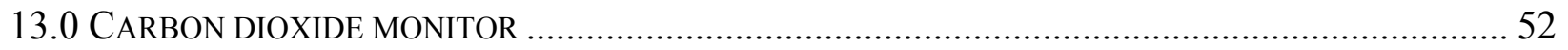

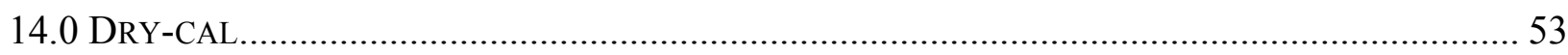

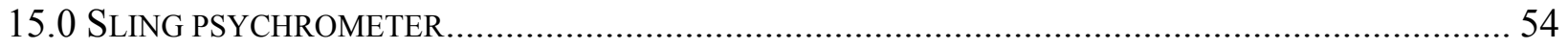

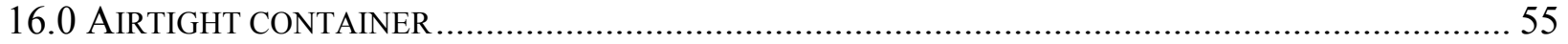

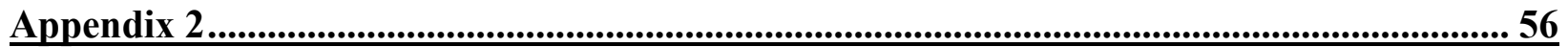

LOW FLOW, HIGH FLOW SAMPLING PUMP CALIBRATION PROCEDURE ...................................... 56

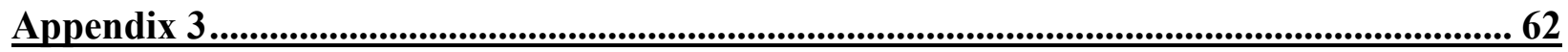

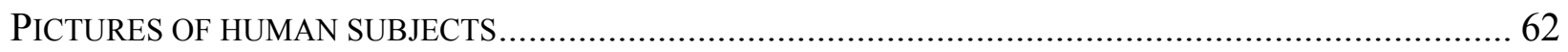

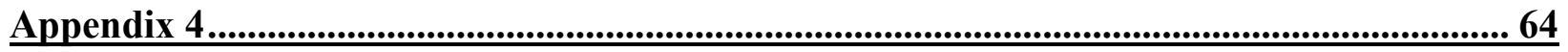

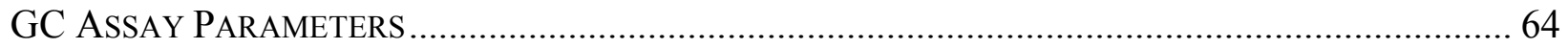

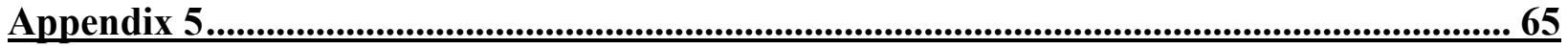

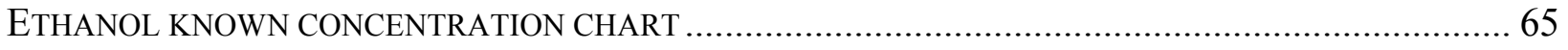




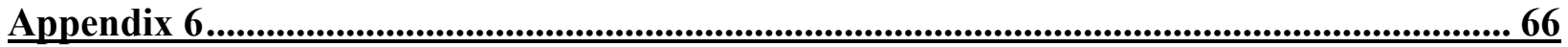

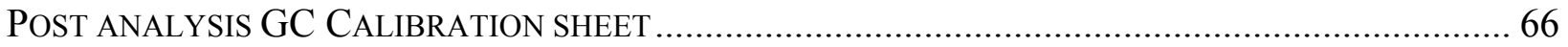

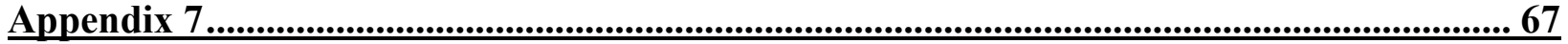

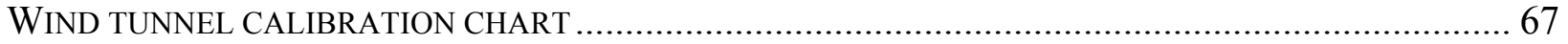

Appendix 8

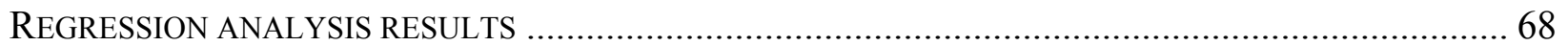

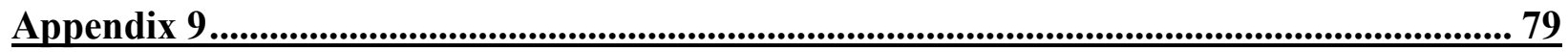

PLOTS OF DEPENDENT VARIABLES VS. INDEPENDENT VARIABLES............................................ 79 


\section{LIST OF FIGURES}

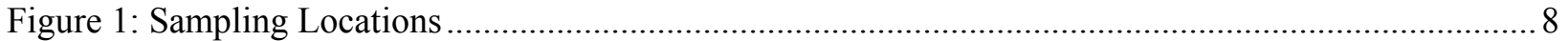

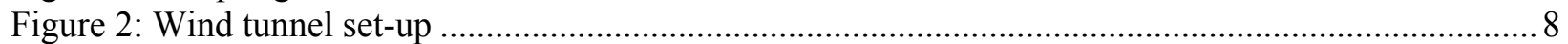

Figure $3: \mathrm{C}_{\text {nose }}$ vs. Sampling rate at nose for all subjects ..................................................................... 13

Figure 4: $C_{\text {chest }}$ vs. Sampling Rate at the Nose (all subjects)................................................................. 14

Figure 5: $\mathrm{C}_{\text {chest }} / \mathrm{C}_{\text {nose }}$ vs. Sampling Rate at the Nose (all subjects) .......................................................... 14

Figure 6a: $\mathrm{C}_{\mathrm{nose}}$, all velocities, all subjects................................................................................ 15

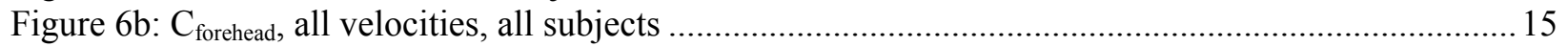

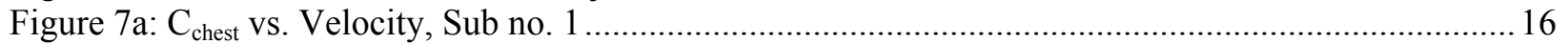

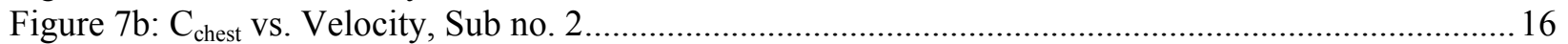

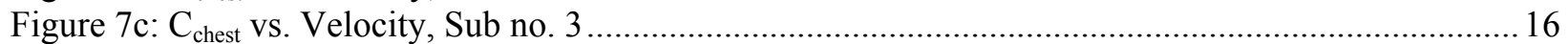

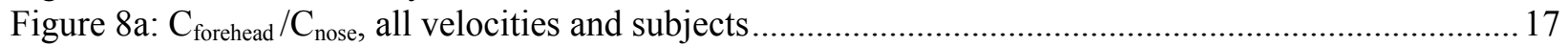

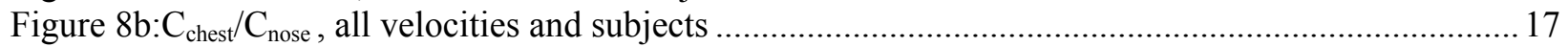

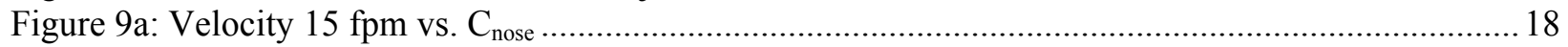

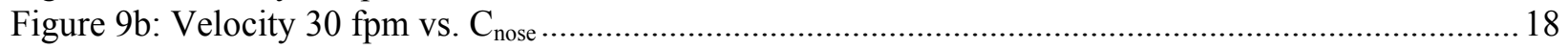

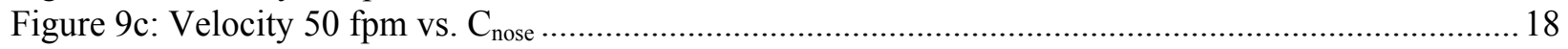

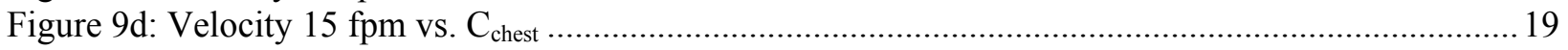

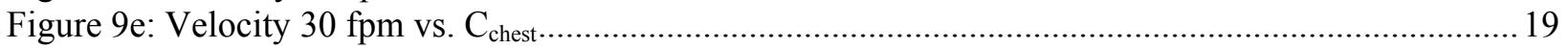

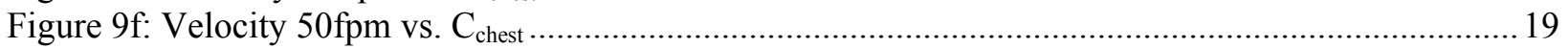

Figure 10a: $C_{n e c k}$ vs. shoulder width all subjects and velocities............................................................20

Figure 10b: $\mathrm{C}_{\text {chest }}$ vs. shoulder width all subjects and velocities .............................................................2 20

Figure 10c: $\mathrm{C}_{\text {nose }}$ vs. shoulder width all subjects and velocities.............................................................2 21

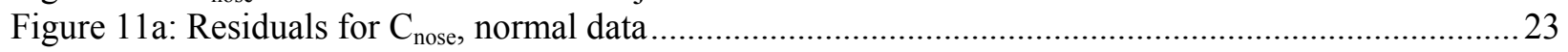

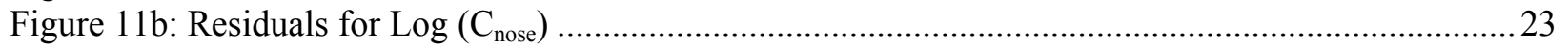

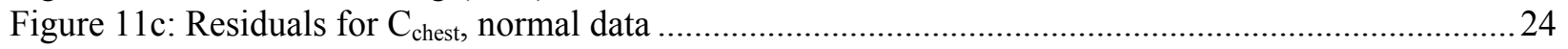

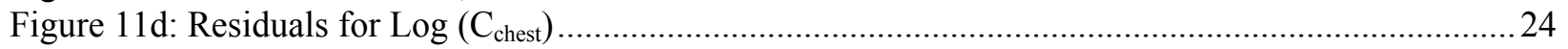

Figure 11e: Residuals for $\mathrm{C}_{\text {forehead }}$ normal data..............................................................................2.

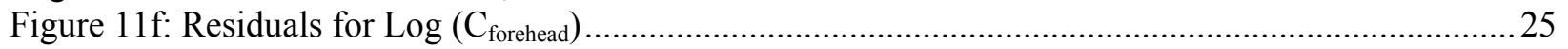

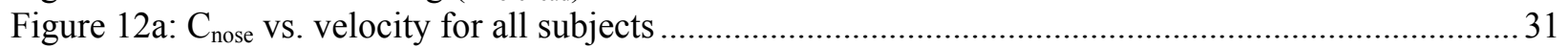

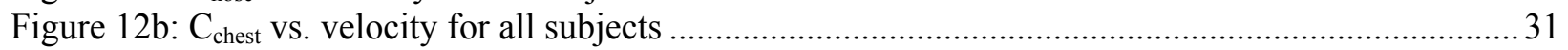

Figure Appendix 1.1 Wind tunnel with mannequin.............................................................................. 37

Figure Appendix 1.2 Front view of the Wind tunnel with mannequin......................................................38

Figure Appendix 2.1:Gas Chromatograph ......................................................................................... 39

Figure Appendix: 3.1 Respiband .............................................................................................. 41

Figure Appendix: 3.2 Respitrace Plus........................................................................................... 42

Figure Appendix: 4.1 Rotameter............................................................................................... 43

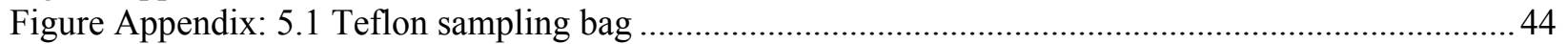

Figure Appendix: 6.1 Syringe pump used to inject ethanol liquid .......................................................4

Figure Appendix: 6.2 Ethanol Syringe ……………………………………………………..... 45

Figure Appendix: 7.1 Experimental set-up .................................................................................. 46

Figure Appendix 8.1 High flow Pump ………………………………………………………..... 47

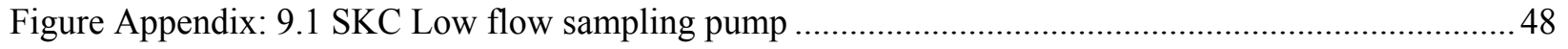

Figure Appendix: 10.1 Manual syringe …………………………………………………………... 49

Figure Appendix: 11.1 Fortin type mercurial barometer ………………………………………………. 50

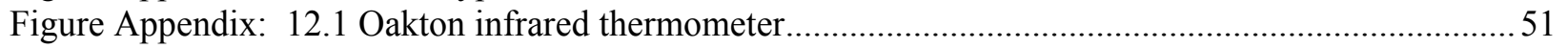

Figure Appendix: 13.1 Carbon dioxide monitor …………………………………………………...5

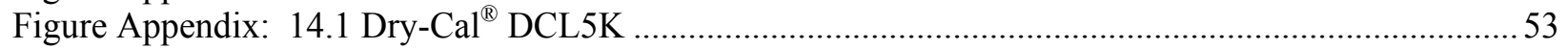

Figure Appendix: 15.1 Sling psychrometer ............................................................................. 54

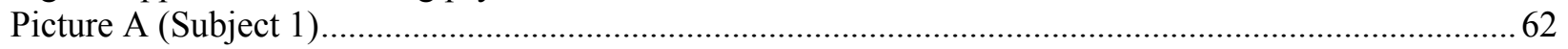




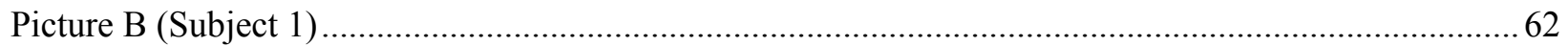

Pictures A and B: Human Subject Connections at Sampling Locations .............................................. 62

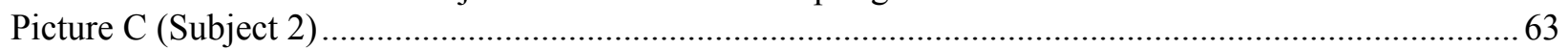

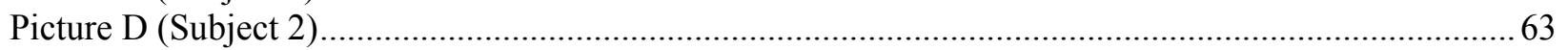

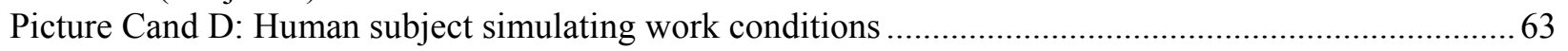

Figure Appendix 16.1: All $\mathrm{C}_{\text {nose }}$ data with wind tunnel Velocity ............................................................79

Figure Appendix 16.2: All $\mathrm{C}_{\text {neck }}$ data with wind tunnel Velocity ............................................................ 79

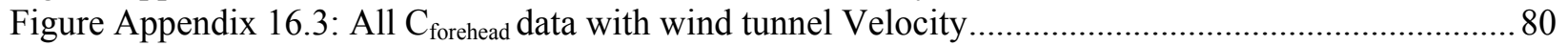

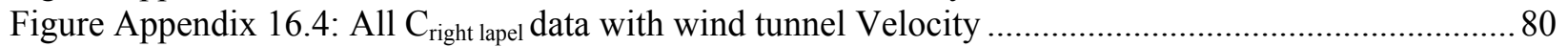

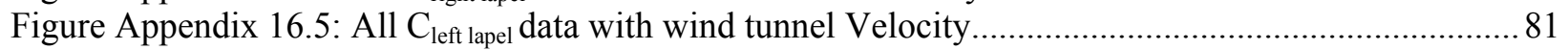

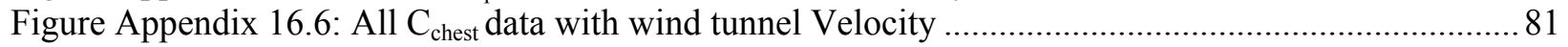

Figure Appendix 17.1: All $\mathrm{C}_{\text {nose }}$ data with Chest circumference ......................................................... 82

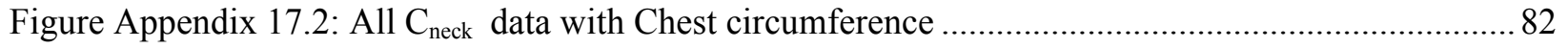

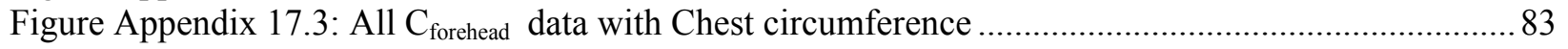

Figure Appendix 17.4: All $\mathrm{C}_{\text {right lapel }}$ data with Chest circumference ...................................................... 83

Figure Appendix 17.5: All $\mathrm{C}_{\text {left lapel }}$ data with Chest circumference ....................................................... 84

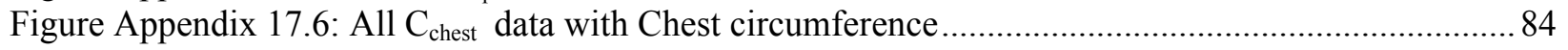

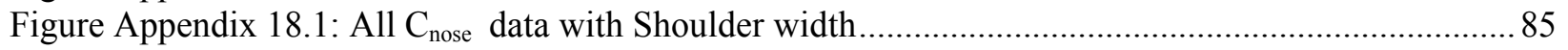

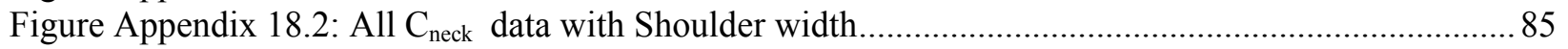

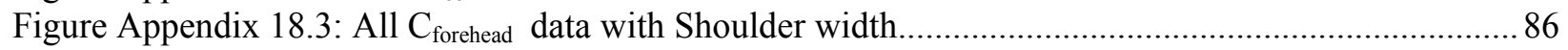

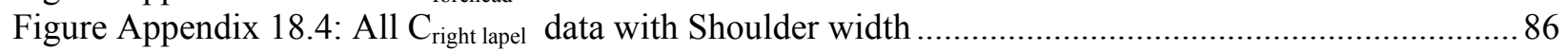

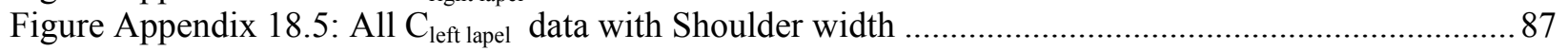

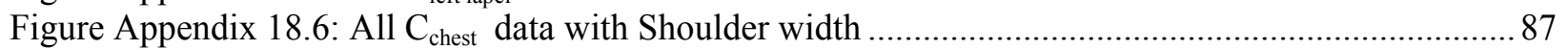

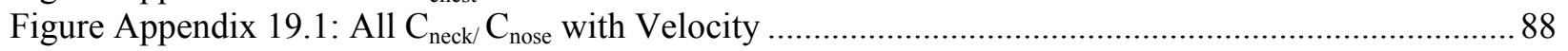

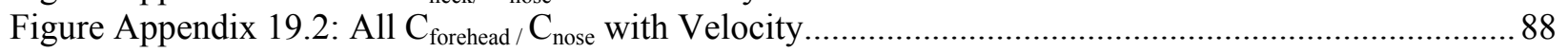

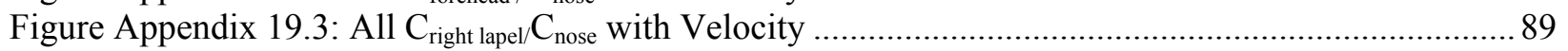

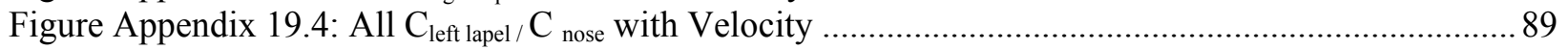

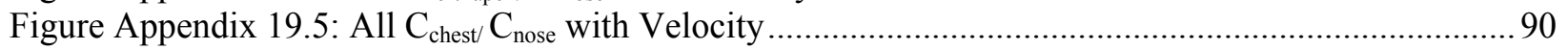

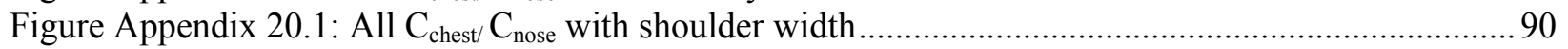

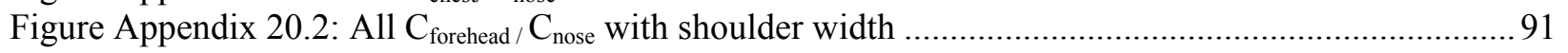

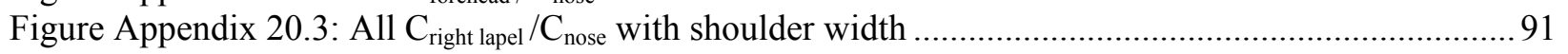

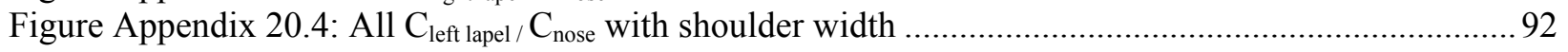

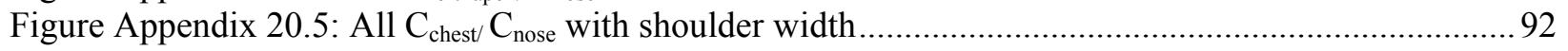

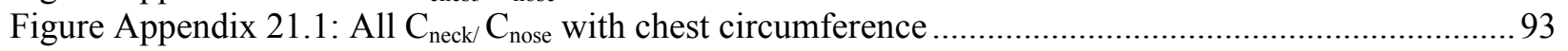

Figure Appendix 21.2: All $\mathrm{C}_{\text {forehead }} \mathrm{C}_{\text {nose }}$ with chest circumference ......................................................93

Figure Appendix 21.3: All $\mathrm{C}_{\text {right lapel }} \mathrm{C}_{\text {nose }}$ with chest circumference .................................................. 94

Figure Appendix 21.4: All $\mathrm{C}_{\text {left lapel }} / \mathrm{C}_{\text {nose }}$ with chest circumference ................................................... 94

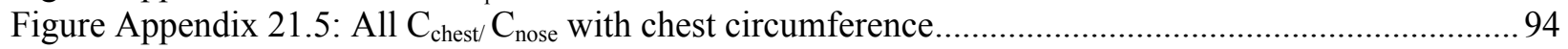




\section{LIST OF TABLES}

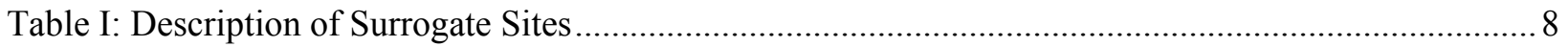

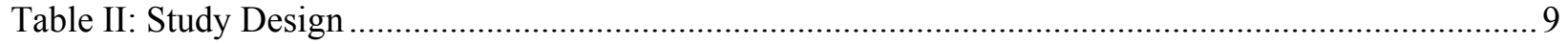

Table III: Mean concentrations of all sampling locations for all velocities............................................ 12

Table IV: Independent and Dependent variables used in the study................................................ 13

Table V: Regression analyses of non-transformed variables ............................................................26

Table VI: Regression coefficients results based on individual non-transformed concentrations ..............27

Table VII: " $p$ " values form the Regression analyses of non-transformed independent variables on ratio of

individual concentrations at locations to concentration at the nose ...................................................22

Table VIII: Regression coefficients of non-transformed independent variables on ratio of individual

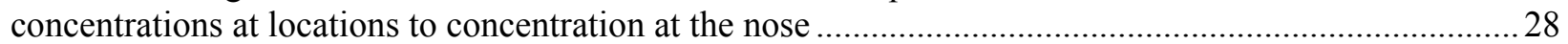

Table IX: "p" values form the Regression results based on individual log-transformed concentrations. ..28

Table X: Regression coefficients results based on individual Log-transformed concentrations ................29

Table XI: Effect of Log-transformed independent variables on ratio of individual concentrations at

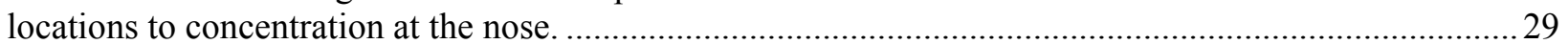

Table XII: Regression coefficients based on ratio of Log-transformed concentrations to Nose ................. 30

Table XIII: Apparatus required for calibration of sampling pumps ..................................................56

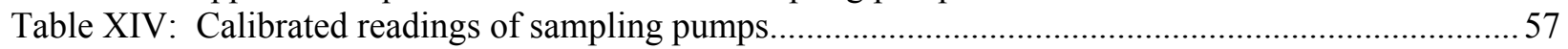

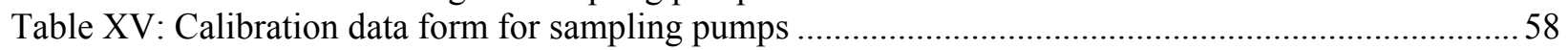

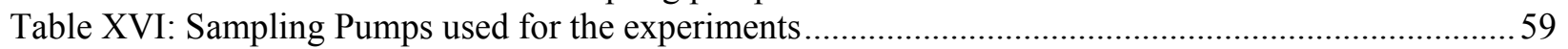

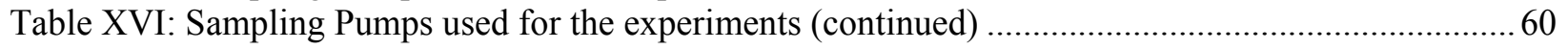

Table XVII: Sampling Pumps used for the experiments (internal coding numbers) ................................61

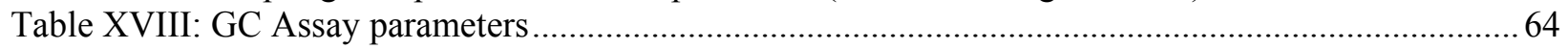

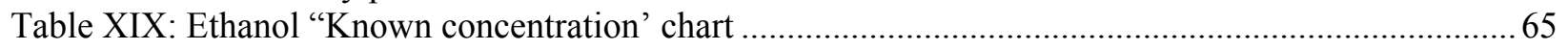

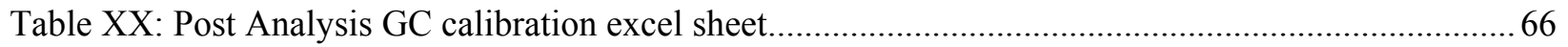

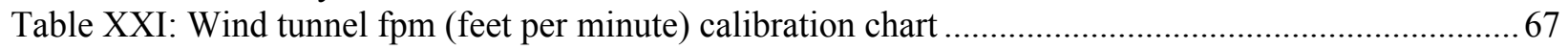

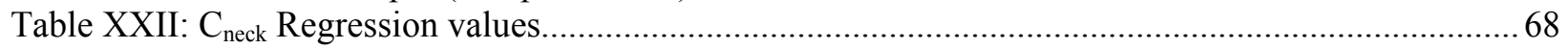

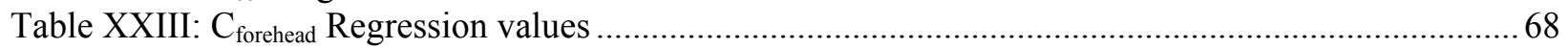

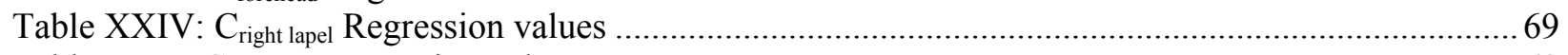

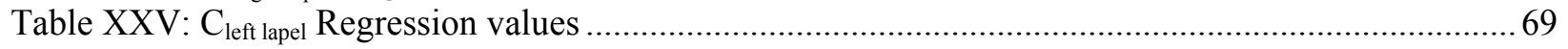

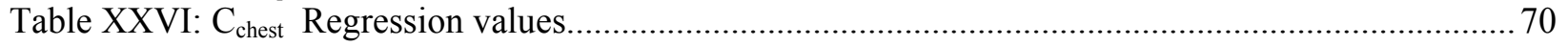

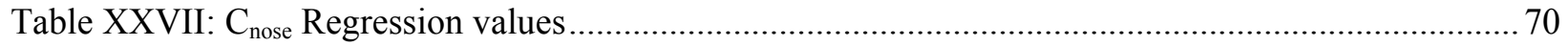

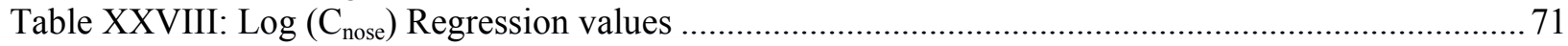

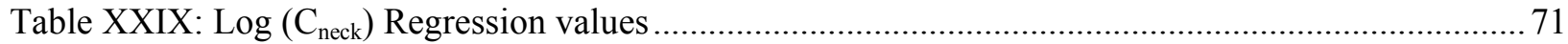

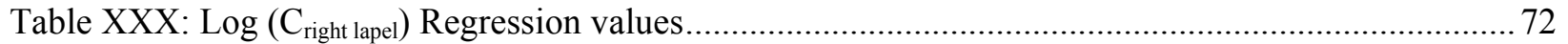

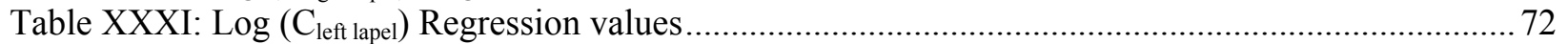

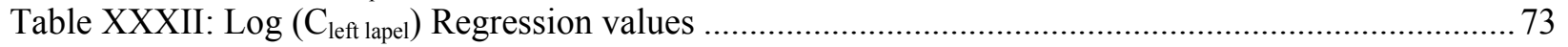

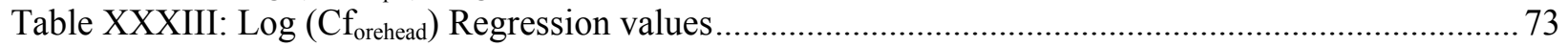

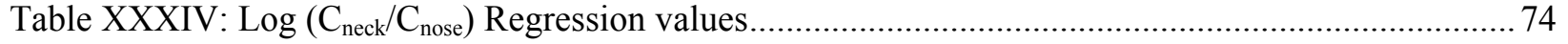

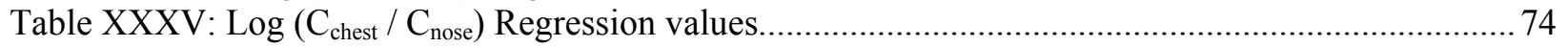

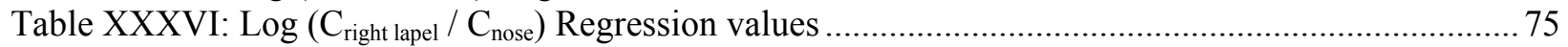

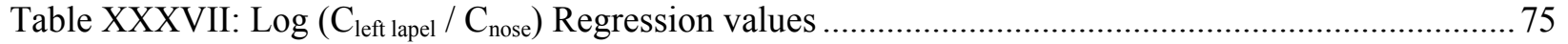

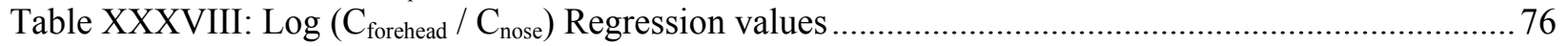

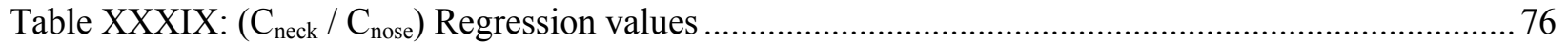

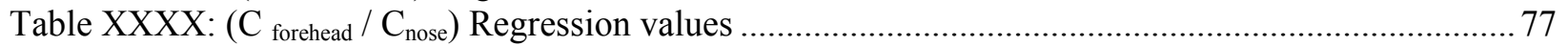

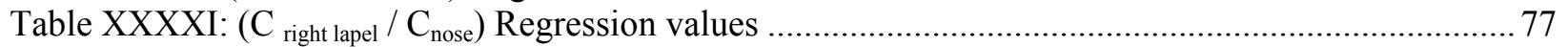

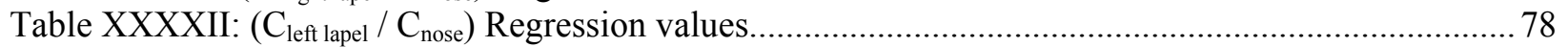

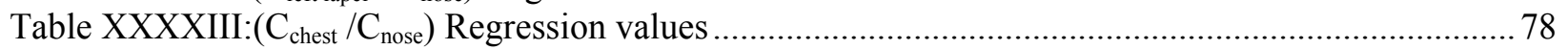




\section{Introduction}

Personal exposure assessment is one of the most important areas in industrial hygiene practices; one must select the work zone to be sampled, the individuals that need to be sampled, the precise location to be sampled, and the sampling parameters. Among these, the precise location on the body to be sampled has not been considered an important parameter. Current exposure assessment practices recommend that the sampler be attached in the "breathing zone" of the individual to be sampled. The location recommended is the lapel.

Currently there is no proof that the lapel is a site whose concentrations closely represent inhaled concentrations.

Kim et $a l^{(1)}$ in a study of air flow pattern around a worker in a uniform free stream showed that the airflow around the worker can be affected by activity level and surface irregularities (e.g. hair, hat and clothing).

Flynn $e a^{(2)}$ developed mathematical models to estimate the worker exposure and concluded that there can be differences in the exposures among workers as a function of the workers size, as well as the contaminant generation rate and the air velocity.

Concentrations may vary to a considerable extent even within the "breathing zone", depending on the location of the source. If the source is too close to the sampling location, any site other than the mouth of the nose could give erroneous results that are not representative of the concentration inhaled by the employee.

The purpose of this study was to:

1. To compare the Nose location to 7 other locations in the "breathing zone" and comment on the differences. The concentrations at the nose were assumed to be representative of inhaled concentrations.

2. Determine whether sampling rates can affect sampling results at the nose.

3. Determine if the wind tunnel velocities and variables pertaining to human anthropometry, for different sampling locations affect the relative concentrations. 


\section{Literature Review}

Personal air sampling is one of the most important aspects of industrial hygiene exposure assessment. The concentration in the "breathing zone" is considered to represent inhaled concentration exposure. Though there is no universal definition of the "breathing zone" the OSHA (Occupational Safety and Health Administration) considers the breathing zone to be in a hemisphere forward of the shoulders within a radius of approximately 6-9 inches in front of the mouth. OSHA states that one must attach the collection device to the shirt collar or as close as practical to the nose and mouth of the employee ${ }^{(3)}$.

Currently there is no standard procedure, which specifies a precise sampling location. There is considerable evidence that this lack of precision would be important if concentrations vary by location. Concentrations vary to a considerable extent even within the "breathing zone", depending on the exact location of the source. This may be critically important if the source is too close to the sampling location. Hence the position of the source could be a very important parameter in the exposure analysis. If the employee has the source near the lapel it is very obvious that the lapel concentrations could be much higher than the inhaled concentration, on the other hand if the source were very near to the nose for a particular task then the nose concentrations would be higher, than the concentrations at the lapel. There are no published data that validate the chest as a good location for representing the concentration inhaled. Indeed, significant concentration differences have been reported when the sampler is placed in different locations within the supposedly uniform "breathing zone" (Malek, 1993; Chatterjee, 1969).

Cohen et al, ${ }^{(4)}$ in the exposure measurement of styrene found that the concentration measured at the nose for an individual was about $76 \%$ of that measured at the chest. Chatterjee et $a l^{(5)}$ investigated the lead concentrations in a lead acid electric accumulator (battery) factory by attaching two filter heads to the upper chest of the worker, one 5 inches below the other. The mean concentration obtained in the upper position was $22 \%$ less than the lower one. In a study conducted by Donaldson and Stringer ${ }^{(6)}$ in the sampling of beryllium, they found that the type of sampling could produce different results in the same environment. Martinelli et al ${ }^{(7)}$ in monitoring real time aerosol distribution in the breathing zone observed that there was considerable variation between the samples of the forehead, nose and the lapel. They speculated 
that resuspended beryllium dust might have increased the lapel concentrations as relative to the forehead and the nose.

Van Der Val et al ${ }^{(8)}$ in one of the few field experiments conducted, found that for painters showed that, the right lapel concentration on a right-handed painter were over $50 \%$ greater than their respective left lapel concentrations.

In a study measuring worker exposures to styrene vapor in a reinforced plastic industry, Cohen et $\mathrm{al}^{(9)}$ showed that there was significant variation of air concentrations within the workers breathing zone. The concentration measured at the nose for an individual was $76 \%$ of that measured at the chest.

Cohen et $a l^{(5)}$ in another experiment showed variability of concentrations within the breathing zone. Kim et al ${ }^{(1)}$ in a study of air flow patterns around a worker in a uniform free stream showed that the airflow around the worker can be affected by activity level and surface irregularities (e.g. hair, hat and clothing).

Kim et $a l^{(10)}$ in another study showed that the reductions in the breathing zone of $30-50 \%$ were observed with other distributional factors such as the presence of a flat plate downstream of the worker. The worker's motion, and the distance between the source and the body, significantly affected results.

Rodes et al ${ }^{(11)}$ suggested the importance of locating the personal monitor as near as practical to the "breathing zone". The study further suggested that a realistic mannequin be used for studies that relate flow and concentration studies.

Kulmala $e t a l^{(12)}$ in a study of the effects of contaminant source location in the near wake region showed that the breathing zone concentration decreases rapidly as the distance of the contaminant source from the body increases. Johnson et al ${ }^{(13)}$ studied the air movement around the worker in a low speed flow field and suggested that a mannequin selected for sampling studies should be heated, rounded, and breathing, and should resemble a human subject with clothes as much as possible.

Flynn et $a l^{(14)}$ developed mathematical models to estimate the worker exposure. They concluded that there could be a difference in the exposures between workers as a function of workers size, generation rate and the air velocity. The workers location with respect to the source of pollutant was thought to be critical. 
Malek et $a l^{(15)}$ measured concentration variations in a boat manufacturing plant where the average air velocity in the workers breathing zone was $60-80 \mathrm{ft} / \mathrm{min}$. The study concluded that there was no correlation between the left lapel and the right lapel concentrations and strongly suggested that the ideal location to sample was the chest; because the chest concentration was higher than that of the nose.

Welling et $\mathrm{l}^{(16)}$ found that arm movement had the same effect as a fan causing variations in velocity and concentration in the breathing zone. The presence of a table and arm movement at the source level increased the concentration slightly.

Guffey et $a l^{(17)}$ in a mannequin study found that the concentrations at the chest were 2.9 times the concentrations at the nose, the ratio decreased with increase in wind tunnel velocities. The ear was considered not a good location to sample, as there was a high variability in the ear concentrations as compared to the nose. The mannequin that was studied did not breathe nor change the posture. The concentrations increased with increase in the wind tunnel velocity. This study used ethanol as a tracer gas. Importantly it has been shown that " The respiratory system absorbed about $62 \%$ of the ethanol form the inspired air at concentrations ranging from $11-19 \mathrm{mg} / \mathrm{L}$. This percentage appeared to be independent of ventilation rates, which ranged from 7 to $25 \mathrm{~L} / \mathrm{min}$." In another study of the absorption of ethanol in the respiratory system, in two subjects with ventilation rates of $15 \mathrm{~L} / \mathrm{min}$, the concentration profiles suggested that the blood concentration reached equilibrium after 3 hours ${ }^{(18)}$.

In this study, concentration was less than $100 \mathrm{ppm}$ and subjects were exposed to less than 3 hours. Hence, saturation should not be reached. 


\section{Apparatus and Procedure}

All the experiments for this study were conducted in a custom- designed and constructed wind tunnel. The wind tunnel was 9'x12'x40' and had HEPA filters flow straigthners (AstroCel I

$\left.{ }^{\circledR}\right)$ at the inlet and on the outlet side. A fan was installed on top of the wind tunnel to suck the air from inside the wind tunnel. A Photovac, Voyager Gas Chromatograph (GC) was used to analyze the ethanol content from the sampled bags. The Respitrace (NIMS) was used to sense the inhalation and the exhalation of the subject. SKC low flow (model 222-3) and the high flow sampling pumps (224-PCXR4) were used to sample the air at different locations on the human subject.

Three human subjects participated in the experiments. Pure liquid ethanol was evaporated into $1 \mathrm{lpm}$ of $99.99 \%$ pure nitrogen and pushed by the nitrogen cylinder pressure. The rotameter was used to measure and control nitrogen flow. A syringe pump was used to control the flow of liquid ethanol going in a half-gallon glass jar, where it was evaporated into the nitrogen. A digital thermometer was used to measure temperature of the wind tunnel walls and floor. Relative humidity measurements were done with the help of the sling psychrometer. A mercury barometer was used to measure the barometric pressure inside the room housing the wind tunnel. For detailed explanation of the equipments see Appendix 1.

\section{Procedure}

The study design is described in Table II. Procedures were set up as listed below:
A. Preparation sampling system prior to experiment runs
B. Tracer Gas release system
C. Fan speed and environmental conditions
D. Subject preparation procedure
E. Sampling
F. Analysis of ethanol bag samples
G. Post -analysis calibration. 


\section{A) Preparation sampling system prior to experiment runs}

1. The Teflon bags required for sampling were purged with 2 liters clean air (ambient air) by injecting air into them with a 3-liter manual syringe pump.

2. The Teflon bags were then gently tapped to mix the clean air uniformly and were left inside a laboratory hood for 5 minutes.

3. The Teflon bags were then tested for leaks by immersing them fully inside a water bath and observing the escape of air bubbles.

4. The Teflon bags were manually rolled and pressed inside the lab hood to empty them.

5. Labels identifying with location, wind tunnel flow rate and sampling pump flow rate were affixed on each bag, e.g. Nose, $15 \mathrm{fpm}$, and $11 \mathrm{pm}$ and date of the run.

6. Teflon bags were connected to the exhaust port of the sampling pumps.

7. Liquid ethanol was poured into a $125 \mathrm{ml}$ glass vial inside the lab hood.

8. The low flow pumps and the high flow pumps were calibrated prior to use. The calibration procedure and the readings are mentioned (see Appendix 2).

9. The wind tunnel conditions (temperature, humidity, subject measurements) were noted.

10. Male-female connectors were fitted for the mixing chamber, sampling pumps inlet outlet, Teflon sampling bags, the sampling lines, and the GC connection to the Teflon sampling bags and checked for leaks.

B) Tracer Gas release system

1. Nitrogen was allowed to flow via the 2-stage regulator to the rotameter, and the rotameter flow was adjusted to $1 \mathrm{lpm}$.

2. The power supply to the resistor (covered with Aluminum foil-inside the mixing chamber) was turned on, and adjusted to $6 \mathrm{~V}, 1.5 \mathrm{~A}$.

3. The ethanol syringe was filled with $50 \mathrm{ml}$ of liquid ethanol. The ethanol syringe was connected to the mixing chamber and adjusted such that the liquid ethanol droplets would directly fall on the resistor wrapped in aluminum foil placed inside the mixing chamber.

4. The ethanol syringe pump flow rate was adjusted at $0.062 \mathrm{ml} / \mathrm{min}$ for some tests and $0.074 \mathrm{ml} / \mathrm{min}$ for the other tests. 
C) Fan speed and environmental conditions

1. The wind tunnel fan speed was set as per the random order of experiments.

2. The sampling pumps (either low- flow- pumps or the high- flow- pump, as the case may be) were connected to the Teflon sampling lines.

3. The temperature, humidity inside the wind tunnel was recorded.

4. The atmosphere pressure inside the room was recorded.

D) Subject preparation procedure

1. The chair height was set so that the subjects naval were even with the tabletop. (See Appendix 3, Pictures A and B).

2. The subject was allowed to sit on the chair provided near the table.

3. The Respitrace bands were attached to the human subject and the tension in these bands was checked to verify that the exhalation and inhalation of the human subject was correctly detected.

4. The Respitrace response was again checked with the actual inhalation and exhalation cycle of the human subject. The inhalation and exhalation pumps were checked to verify that they started and stopped appropriately with the actual exhalation and inhalation of the subject.

5. The sampling lines were then attached on the human subject (see Table I and Figures 1 and 2).

6. A randomly selected sequence of experiments (see Table II) was followed for each subject. One replication was done per subject.

7. The subject was instructed to lift children's play box from one side of the source and stack them on the other side. When all were moved to one side, the task was repeated in the other direction. 


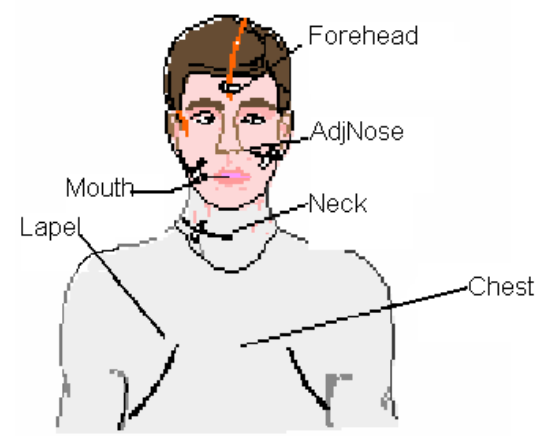

Figure 1: Sampling Locations

Table I: Description of Surrogate Sites

\begin{tabular}{|l|l|}
\hline Description & Location \\
\hline $0.5 \mathrm{~cm}$ laterally from nasal orifice & Nose \\
\hline $\begin{array}{l}4^{\text {th }} \text { intercostal space on the right mid- } \\
\text { clavicular line }\end{array}$ & Right lapel \\
\hline $\begin{array}{l}4^{\text {th }} \text { intercostal space on the left mid-clavicular } \\
\text { line }\end{array}$ & Left lapel \\
\hline Sternoclavicular region & Neck \\
\hline $\begin{array}{l}\text { On the orbital midline } 2 \mathrm{~cm} \text { above the brow } \\
\text { ridge }\end{array}$ & Forehead \\
\hline Center of Right lapel and Left lapel & Chest \\
\hline
\end{tabular}

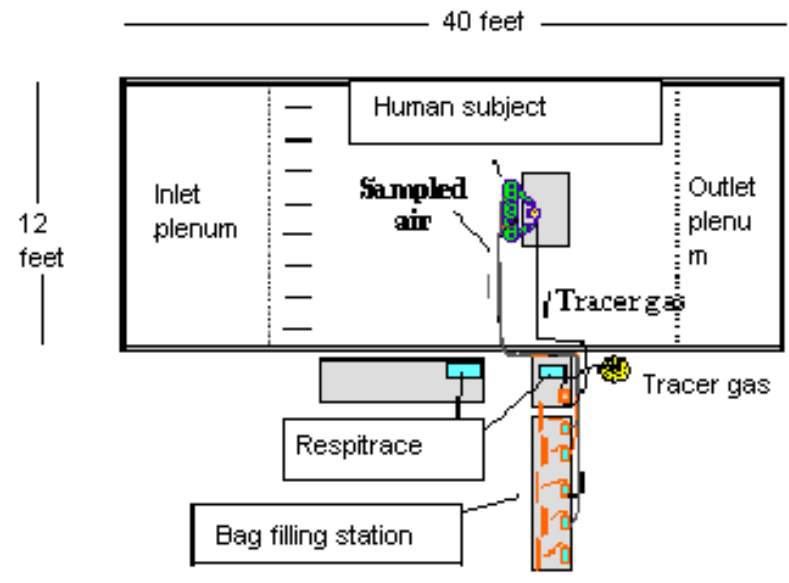

Figure 2: Wind tunnel set-up 
Table II: Study Design

\begin{tabular}{|l|l|}
\hline $\begin{array}{l}\text { Number of subjects }=3 \\
\text { Number of Replications }=2\end{array}$ & $\begin{array}{l}\text { Time for each test }=15 \text { minutes } \\
\text { Total number of tests }=24\end{array}$ \\
\hline Type of design & Randomized block \\
\hline Dependent variables & $\begin{array}{l}\text { Concentration of Ethanol at locations } \\
\text { mentioned in Table I. }\end{array}$ \\
\hline Independent variables & $\begin{array}{l}\text { Cross draft velocity, Nose sampling rate, } \\
\text { Chest circumference, chest depth, chest width, } \\
\text { shoulder width }\end{array}$ \\
\hline Subject task & Unenergetically stacking children's blocks \\
\hline
\end{tabular}

E) Sampling

1. All sampling pumps and the ethanol syringe pump were switched "ON" as described in preceding pages.

2. The human subject was then asked to unenergetically stack the children's blocks in such a way that the subject's hands cross over the source in a specific pattern in specific time duration.

3. The wind tunnel doors were closed.

4. There was a 5-minute period before starting the sampling pumps, to equilibrate the concentration in the wind tunnel.

5. Sampling bags were "opened" and then attached to the appropriate sampling lines, outside the wind tunnel.

6. Sampling pumps were turned on the bags were allowed to fill for a period of seven minutes.

7. At the end of 7 minutes, the sampled bags were disconnected and manually emptied. This was done to 'pre-treat' each sampling bag.

8. The Teflon bags were then re-attached to the sampling lines

9. The Teflon bags were then re-attached to the pumps and allowed to fill for a period of 15 minutes. At the end of 15 minutes the Teflon bags were disconnected from the pumps and then valves were "closed".

10. The human subject was asked to breathe through a Tygon tube into a different Teflon bag and the bag was marked "Exhaled air after the *** run". These samples were taken to determine whether the subject's breath showed ethanol saturation in the body.

11. Bags were taken to the GC for analysis. 
(*** Symbolizes a particular run)

F) Analysis of ethanol bag samples

1. The Assay window of the software for GC was opened (see Appendix 4).

2. The GC was allowed to operate a "dry" run, in which the GC sampled the ambient air in which a small amount of the sampled air was allowed to draw into the GC, which was initiated using the "Start" button on the screen. This constituted the "analysis". This was done as a check for baseline.

3. After this run the sampled bags from the wind tunnel were "opened".

4. The readings for the peak height $(\mathrm{mV})$, integrated area (mVS) and the retention time ( $\mathrm{sec})$ were displayed on screen and stored in a computer file.

5. Bags were analyzed in no particular sequence.

6. Special observations if any were noted in the results.

G) Post -analysis calibration of the GC

1. The GC was calibrated each day after analyzing samples.

2. The minimum and the maximum values for the intergraded area (mVS) were compared to a standard ppm value (known ppm) (see Appendix 5).

3. The ethanol bottle temperature in degrees Celsius was measured with a calibrated thermometer. The necessary headspace volume to achieve a desired calibration concentration was computed from this temperature.

4. The "known ppm" range was noted for the maximum and minimum values.

5. The concentration range was then divided into 2 or more values.

6. The micro liters derived from the Excel ${ }^{\circledR}$ sheet (see Appendix 6).

7. 2.4 liters of clean, ambient air was injected in a Teflon sampling bag after opening the valve, by using the PDS manual syringe (calibration syringe).

8. The exact amount of Ethanol vapor (saturated headspace) was drawn from the septa of the glass vial half-filled with ethanol. The vapor was injected into each of the Teflon sampling bags and then the bags were closed.

9. The Teflon sampling bags were then gently tapped a few times to ensure good mixing.

10. The bags were then kept in the exhaust hood for 5 minutes. 
11. The Teflon sampling bags were then opened and connected to the GC, and the GC was started. Depending on the pump time that was set in the GC the sample was drawn and a peak voltage $(\mathrm{mV})$, the integrated area $(\mathrm{mVS})$, and the retention time $(\mathrm{sec})$ were noted for each sample drawn.

12. A graph of the "known ppm "and the "mVS" obtained was plotted on a Excel® sheet.

13. The linear fit to the known concentrations and the instrument responses was applied.

14. The test sampling bag concentrations for that day were computed using the linear fit equation for that day. 


\section{Results}

\section{Comparison of concentrations at different locations}

Table III shows the mean concentrations at all velocities (15, 30 and $50 \mathrm{fpm})$ for all sampling locations. As can be observed the mean concentrations increased with increases in the cross draft velocity for all locations. The mean concentration at the chest was the highest amongst all the sampled locations for all treatment conditions. It was substantially higher than $\mathrm{C}_{\text {nose }}$ for all conditions. Concentration at the neck was second highest. The $\mathrm{C}_{\text {forehead }}$ was consistently lower than the $\mathrm{C}_{\text {nose }}$. The rest were sometimes lower and sometimes higher. Note that the $\mathrm{C}_{\text {right lapel }}$ is consistently higher than $\mathrm{C}_{\text {left lapel }}$ perhaps because all subjects were right handed.

Table III: Mean concentrations of all sampling locations for al
\begin{tabular}{|l|c|c|c|}
\hline & \multicolumn{2}{l}{$\begin{array}{l}\text { Concentrations (ppm) } \\
\text { at } \\
\text { Velocity (fpm) }\end{array}$} \\
\hline Sampling Location & 15 & 30 & 50 \\
\hline Forehead (C forehead) & 9 & 16 & 28 \\
\hline Nose(C nose) & 10 & 23 & 30 \\
\hline Neck(C neck & 11 & 30 & 42 \\
\hline Chest(C chest) & 14 & 50 & 51 \\
\hline Right Lapel(C right lapel) & 8 & 29 & 32 \\
\hline Left Lapel(C left lapel) & 5 & 13 & 25 \\
\hline
\end{tabular}

This study investigated the effects of the independent variables on the dependent variables listed in Table IV. The ratios of concentrations of other dependent variables to $\mathrm{C}_{\text {nose }}$ also were studied. 
Table IV: Independent and Dependent variables used in the study.

\begin{tabular}{|l|l|}
\hline Independent variables & $\begin{array}{l}\text { Dependent variables } \\
\text { (sampling location) }\end{array}$ \\
\hline Wind tunnel velocity (fpm) & Forehead \\
\hline Adjacent nose sampling rate (lpm) & Nose (nose) \\
\hline Chest circumference (inches) & Neck \\
\hline Chest width (inches) & Chest \\
\hline Chest depth (inches) & Right Lapel \\
\hline Shoulder width (inches) & Left Lapel \\
\hline
\end{tabular}

\section{Effects of Sampling Rate at the Nose on Concentrations and ratios of concentrations}

One would reasonably expect the sampling rate at the nose to affect the concentration at the nose but not at other sampling locations. The results were as expected. As seen in Figure 3, sampling rate at the nose appeared to affect the concentration at the nose, with a somewhat lower concentration (median $=18.4$ ) at the higher sampling rate than at the lower sampling rate (median $=21.4$ ). As expected, the sampling rate showed no clear visible effect on the concentrations measured at the chest (see Figure 4).

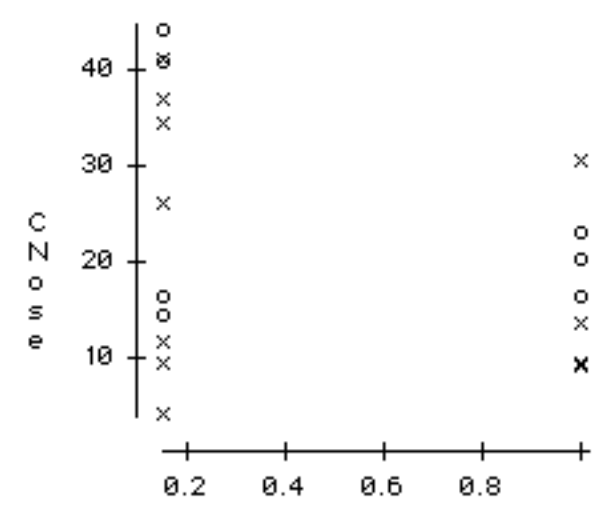

AdjnoseSamplingRate

Figure 3: $\mathrm{C}_{\text {nose }}$ vs. Sampling rate at nose for all subjects

(o-Subject no.1; x- Subject no.2; I-Subject no.3) 
Graphs of results for all locations other than nose showed a similar lack of apparent correlation (not shown).

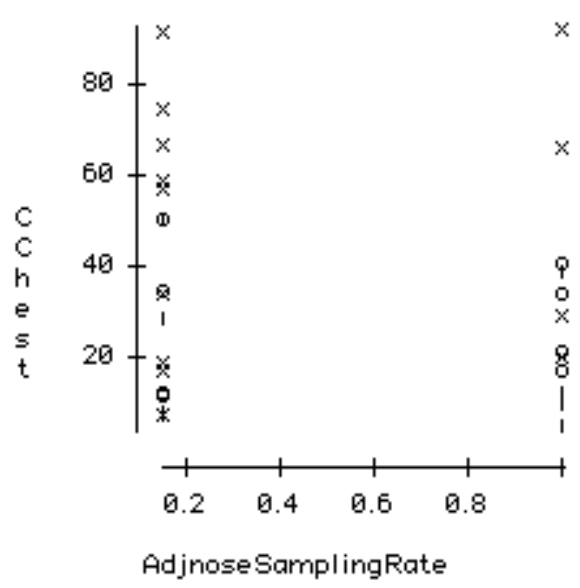

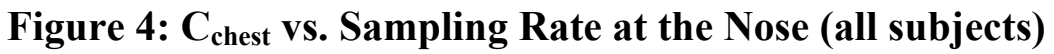

If the concentration at the nose was affected by sampling rate at the nose and no other concentration was affected, then one could reasonably expect that the ratio of other concentrations to nose to also be affected. However, the variance of the ratio would be higher than the variance of each location, perhaps obscuring effects on ratios.

As can be seen on Figure 5, the ratio $C_{\text {chest }} / C_{\text {nose }}$ showed no clear effects of sampling rate at the nose other than one outlying value. That outlier was for a case where the investigators noted no obvious differences from non-outliers. When data were plotted for specific velocities and subjects, no clear interactions with sampling rate were noted.

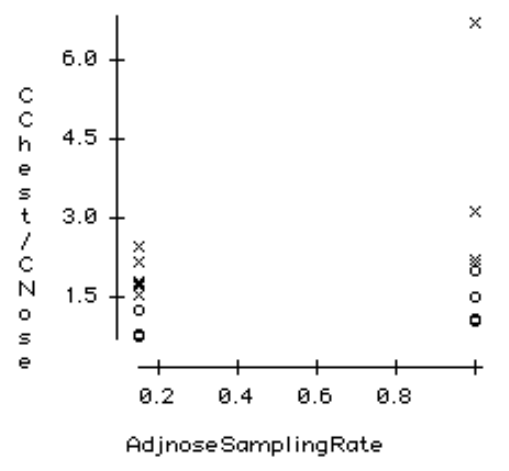

Figure 5: $\mathrm{C}_{\text {chest }} / \mathrm{C}_{\text {nose }}$ vs. Sampling Rate at the Nose (all subjects) 


\section{Effects of cross draft Velocity on Concentrations and ratios of concentrations}

As shown in Figure $6 \mathrm{a}$ and $6 \mathrm{~b}, \mathrm{C}_{\text {forehead }}$ and $\mathrm{C}_{\text {nose }}$ appear to increase sharply with cross-draft velocity in the wind tunnel for all subjects and all wind tunnel velocities.

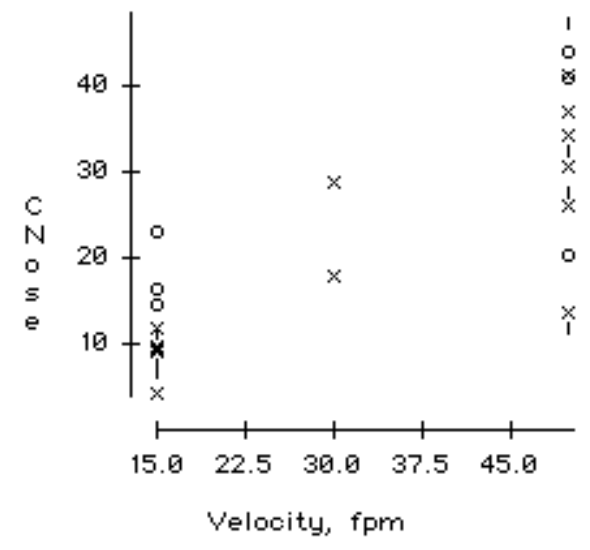

Figure 6a: $\mathrm{C}_{\text {nose }}$, all velocities, all subjects

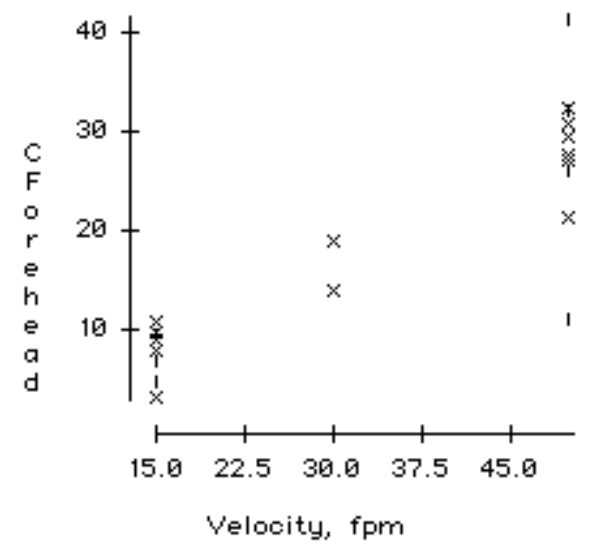

Figure 6b: $\mathbf{C}_{\text {forehead, all velocities, all subjects }}$

As shown in Figures 7a, $7 \mathrm{~b}$ and 7c, a similar pattern was observed for all subjects. Velocity was positively associated with concentration at all other locations. 


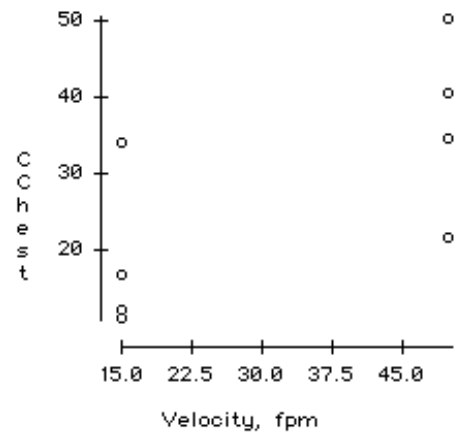

Figure 7a: $C_{\text {chest }}$ vs. Velocity, Sub no. 1

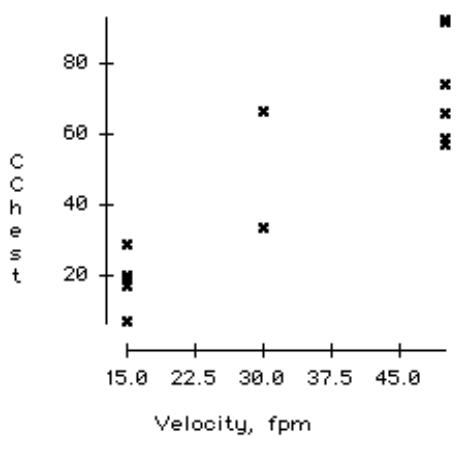

Figure 7b: $C_{\text {chest }}$ vs. Velocity, Sub no. 2

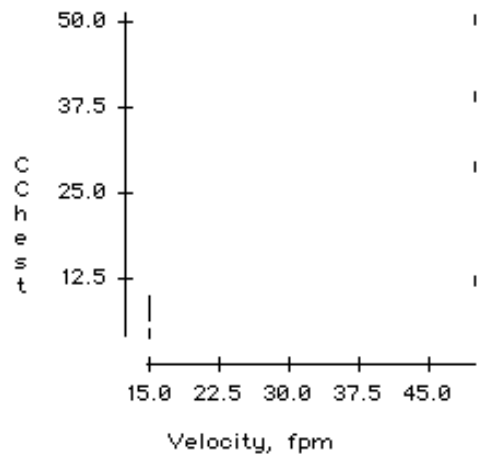

Figure 7c: $C_{\text {chest }}$ vs. Velocity, Sub no. 3 
Figures $8 \mathrm{a}$ and $8 \mathrm{~b}$ show that there is no clear pattern for the ratios of concentration with the velocity. The regression line shown in Figure $8 \mathrm{~b}$ is a straight line is affected by the single outlier value, which imparts a slight slope to the regression line. There is no obvious explanation for the single outlier values in Figures $8 \mathrm{a}$ and $8 \mathrm{~b}$. It was the same subject in both cases.

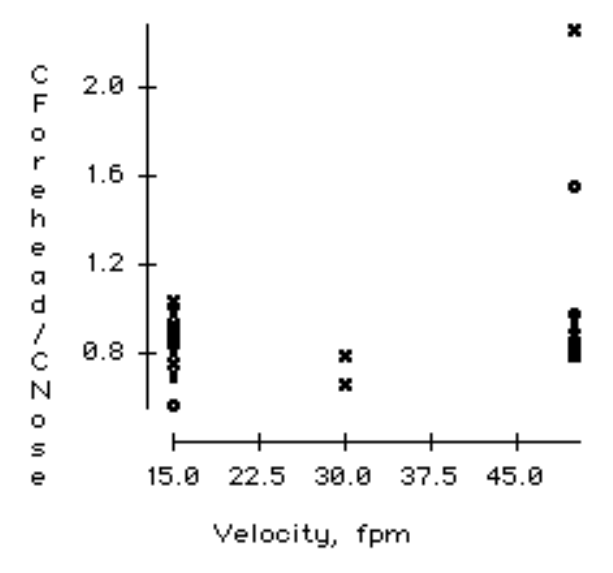

Figure 8a: $\mathbf{C}_{\text {forehead }} / \mathbf{C}_{\text {nose, }}$ all velocities and subjects

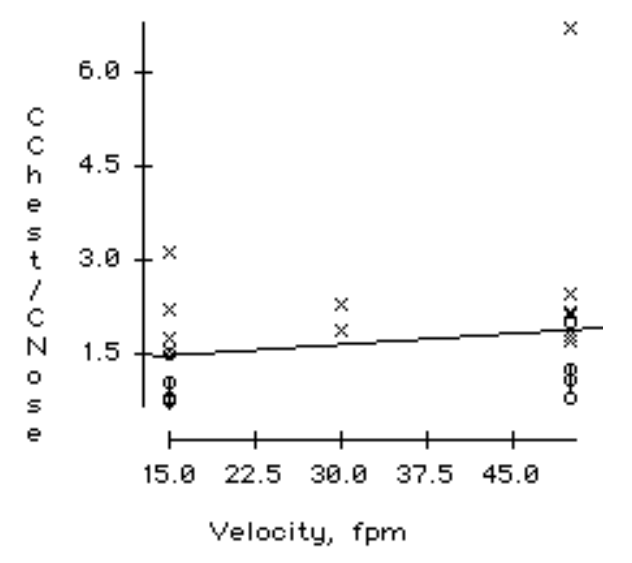

Figure 8b: $C_{\text {chest }} / C_{\text {nose }}$, all velocities and subjects 


\section{Effects of Subjects on Concentrations and ratios of concentrations}

As seen in Figures (9a-9f), $C_{\text {nose }}$ and $C_{\text {chest }}$ values varied substantially among subjects. Subject number 2 had the greatest variability and the highest values, especially for the highest velocity conditions. This subject was the shortest and had a relatively large chest circumference and small shoulder width. Note that the scales vary for these graphs.

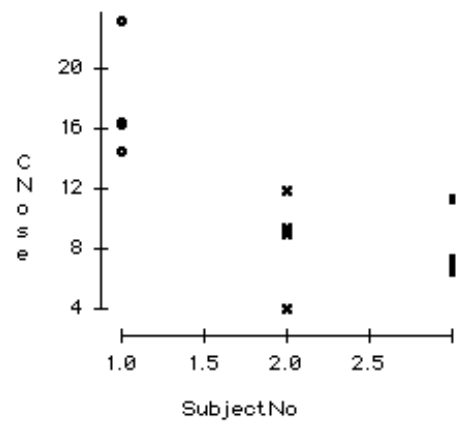

Figure 9a: Velocity 15 fpm vs. $C_{\text {nose }}$

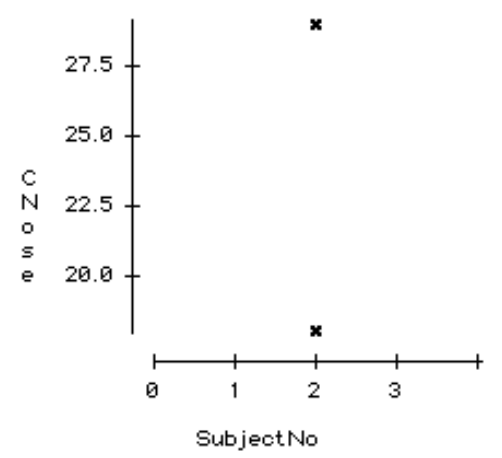

Figure 9b: Velocity 30 fpm vs. $C_{\text {nose }}$

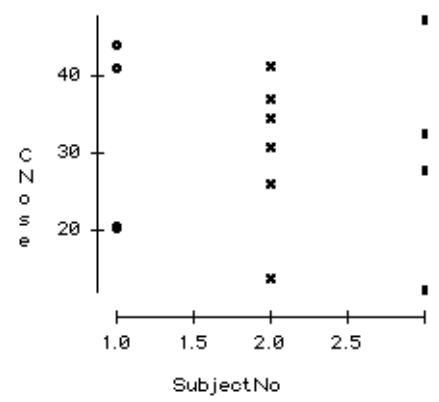

Figure 9c: Velocity $50 \mathrm{fpm}$ vs. $\mathrm{C}_{\text {nose }}$ 


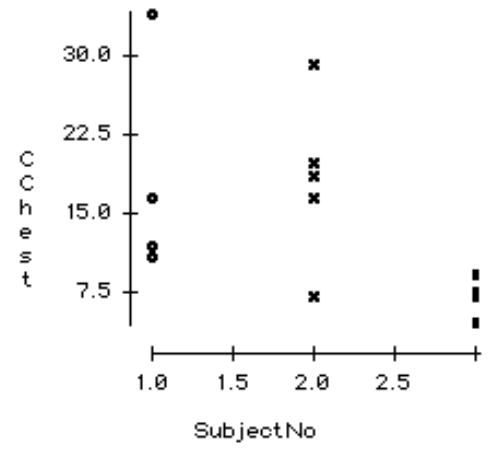

Figure 9d: Velocity 15 fpm vs. $C_{\text {chest }}$

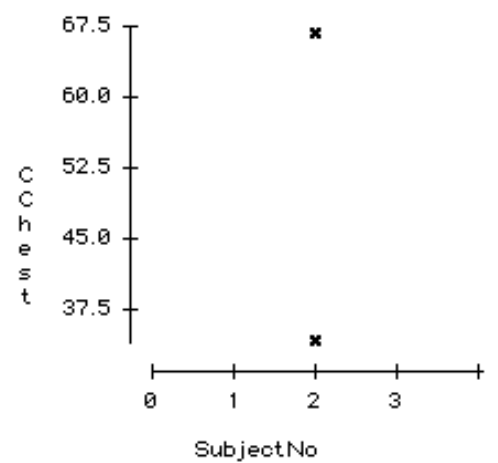

Figure 9e: Velocity $30 \mathrm{fpm}$ vs. $C_{\text {chest }}$

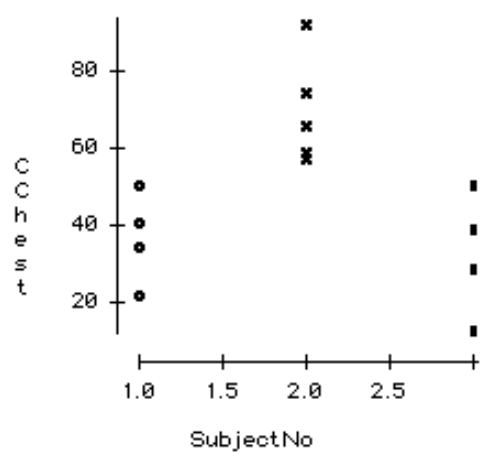

Figure 9f: Velocity 50fpm vs. $C_{\text {chest }}$ 
As seen in Figures 10a, 10b and 10c there is no visible relationship between the concentration at the $\mathrm{C}_{\text {chest }}, \mathrm{C}_{\text {neck }}$ and $\mathrm{C}_{\text {nose }}$ with the shoulder width. A similar pattern was observed for other locations.

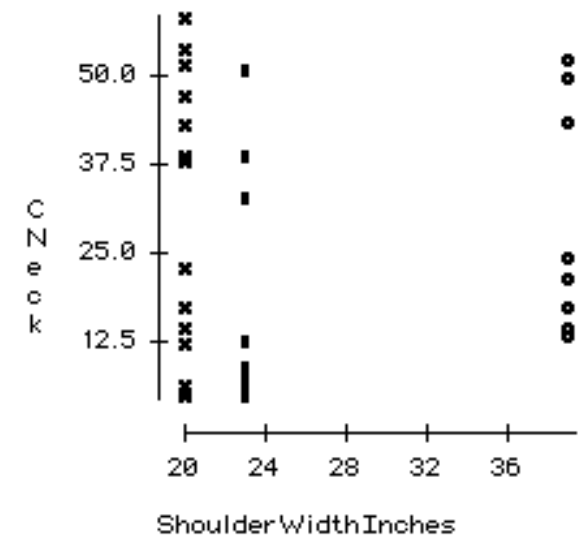

Figure 10a: $C_{\text {neck }}$ vs. shoulder width all subjects and velocities

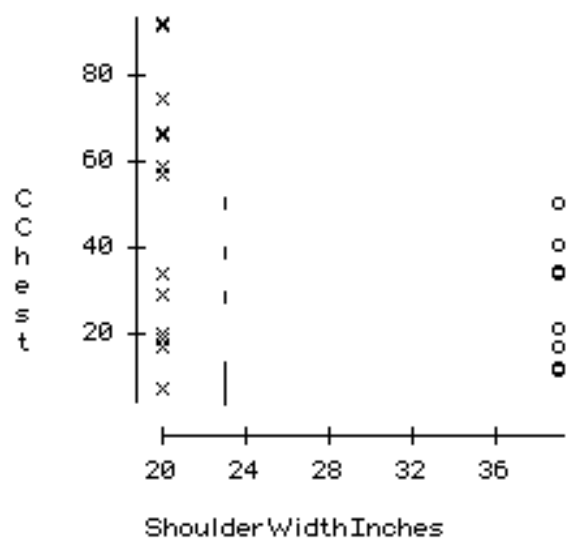

Figure 10b: $C_{\text {chest }}$ vs. shoulder width all subjects and velocities 


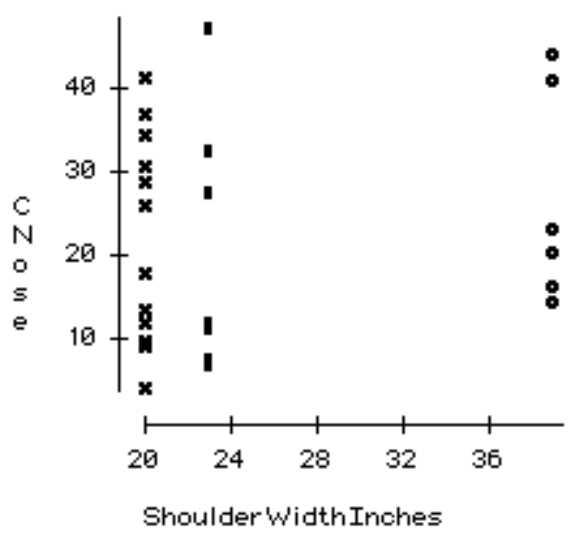

Figure 10c: $C_{\text {nose }}$ vs. shoulder width all subjects and velocities 


\section{Discussion}

Data Desk $^{\circledR}$ (Data Description Inc. Ithaca, NY) software was used to do statistical analysis of the results. The independent variables were the anthropometrical dimensions (chest width, chest circumference, chest depth and shoulder width), the wind tunnel velocities (15 fpm, $30 \mathrm{fpm} 50$ $\mathrm{fpm})$, and adjacent nose-sampling rate $(0.15 \mathrm{lpm}$ and $1 \mathrm{lpm})$. The dependent variables were the concentrations at each probe location and the ratios of those concentrations to the concentration at the nose. The log- transformed values of the dependent and the independent variables also were used to do regression analysis.

\section{Log-transformation of variables}

Generally values are log-transformed with the hope that the resulting residuals will be more normally distributed than untransformed values. In addition, since the log of a ratio is identical to the $\log$ of the numerator minus the $\log$ of the denominator, problems associated with analysis of ratios are avoided.

Legend

\begin{tabular}{|l|l|l|}
\hline Variable & $\begin{array}{l}\text { Variables } \\
\text { Log-transformed }\end{array}$ & Shown in Tables \\
\hline Concentration & No & V, VI \\
\hline Ratio of concentration & No & VII, VIII \\
\hline Concentration & Yes & IX, X \\
\hline Ratio of concentration & Yes & XI, XII \\
\hline
\end{tabular}

For this data residuals from both the transformed and the non-transformed data showed a reasonable degree of normality (see Figures 11a to 11f), with the non-transformed showing a slight advantage for $\mathrm{C}_{\text {nose }}$, neither appeared to be normal. Since there was no clear reason to favor either approach, both normal and log-transformed analyses were done. 


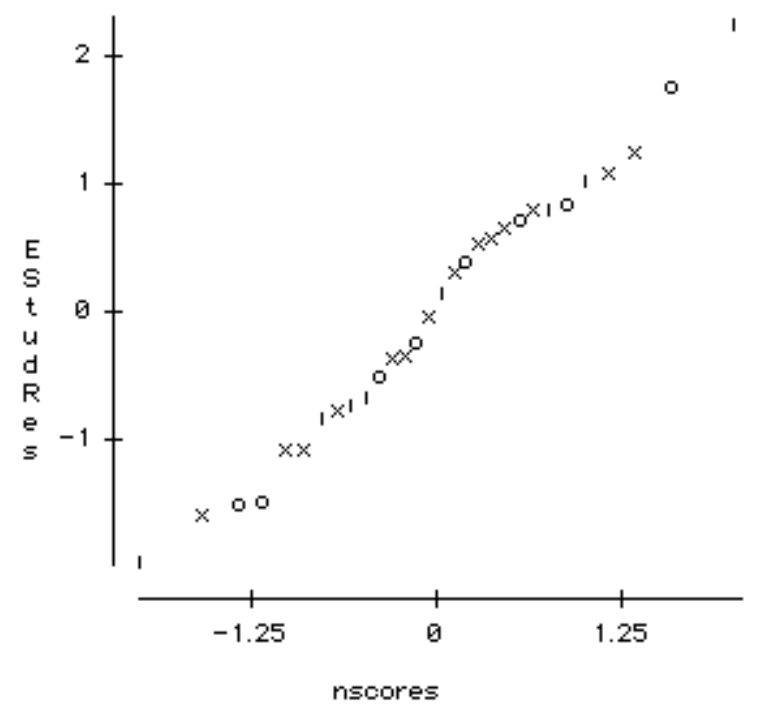

Figure 11a: Residuals for $\mathrm{C}_{\text {nose, }}$ normal data

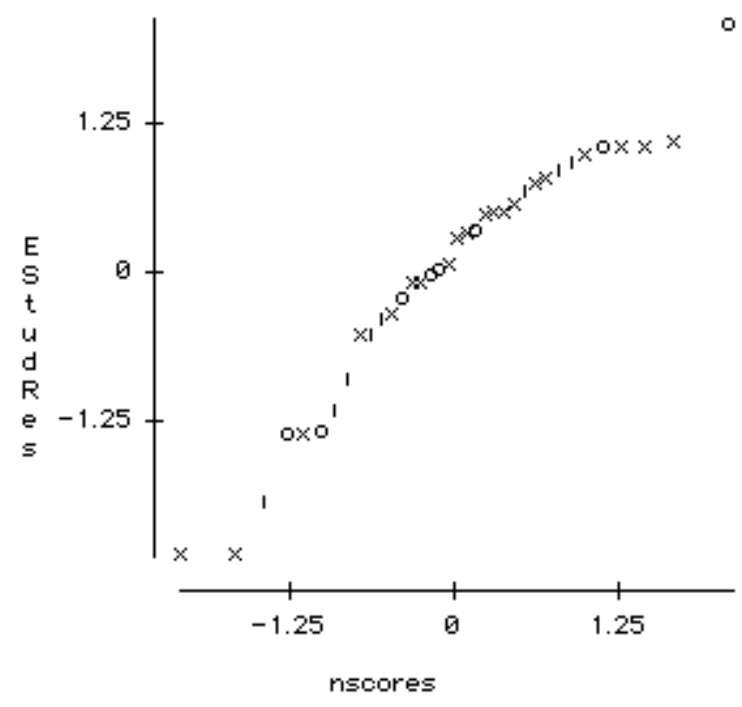

Figure 11b: Residuals for $\log \left(C_{\text {nose }}\right)$ 


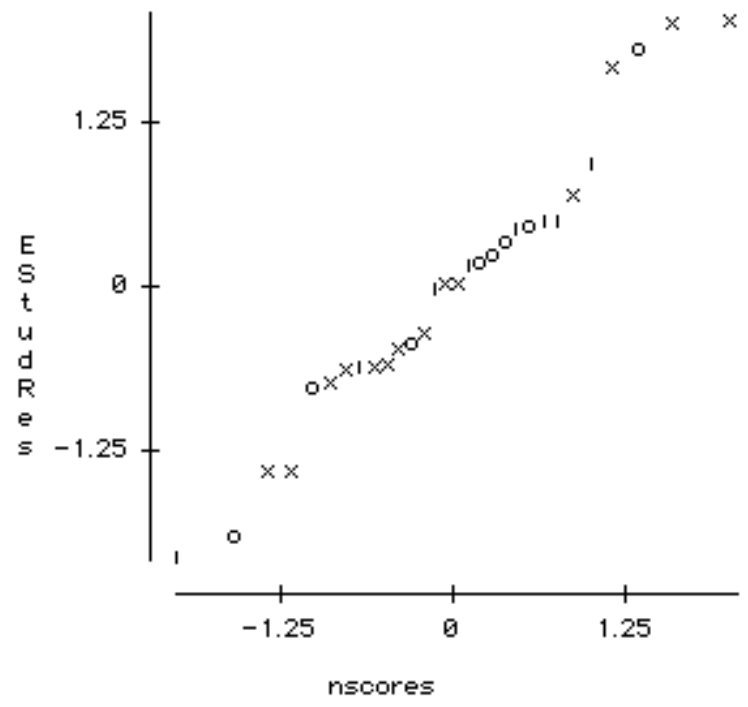

Figure 11c: Residuals for $\mathrm{C}_{\text {chest, }}$ normal data

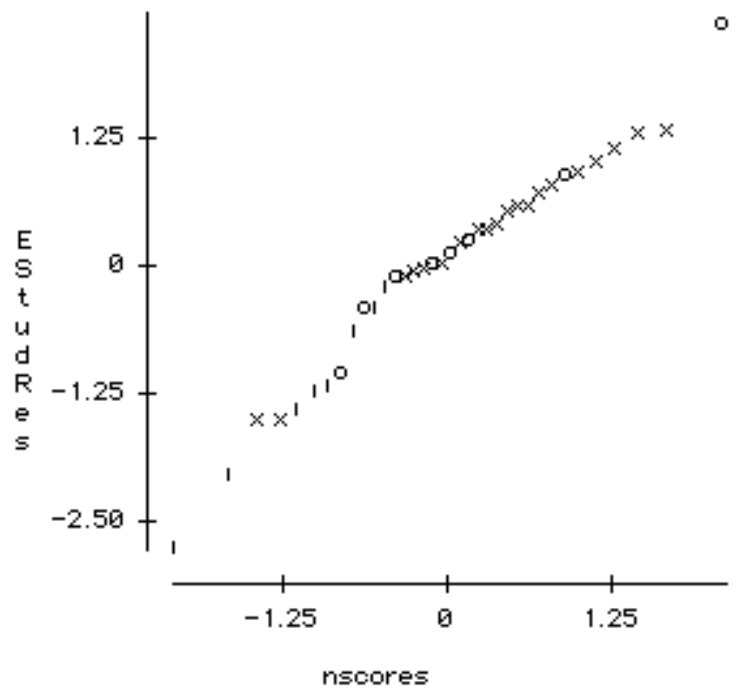

Figure 11d: Residuals for $\log \left(\mathrm{C}_{\text {chest }}\right)$ 


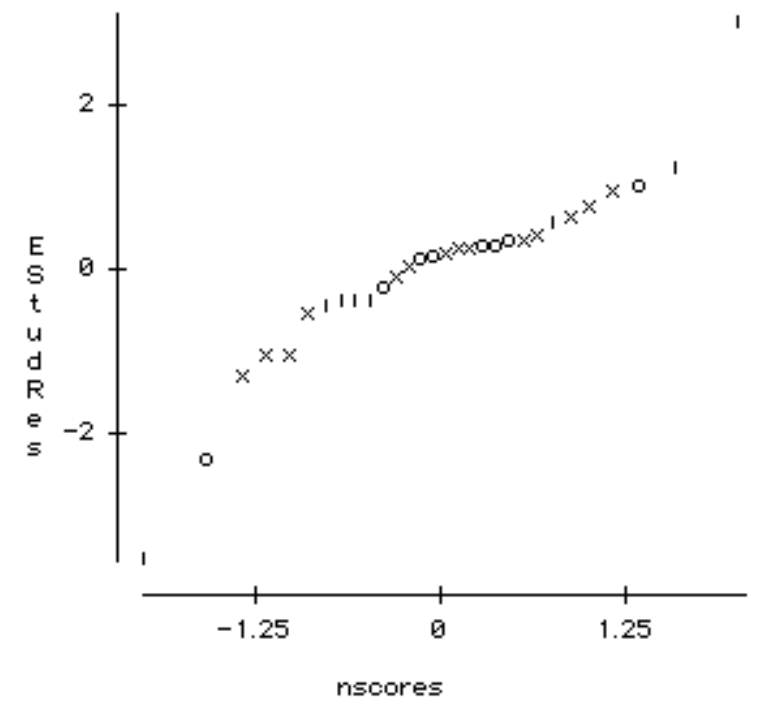

Figure 11e: Residuals for $C_{\text {forehead, normal data }}$

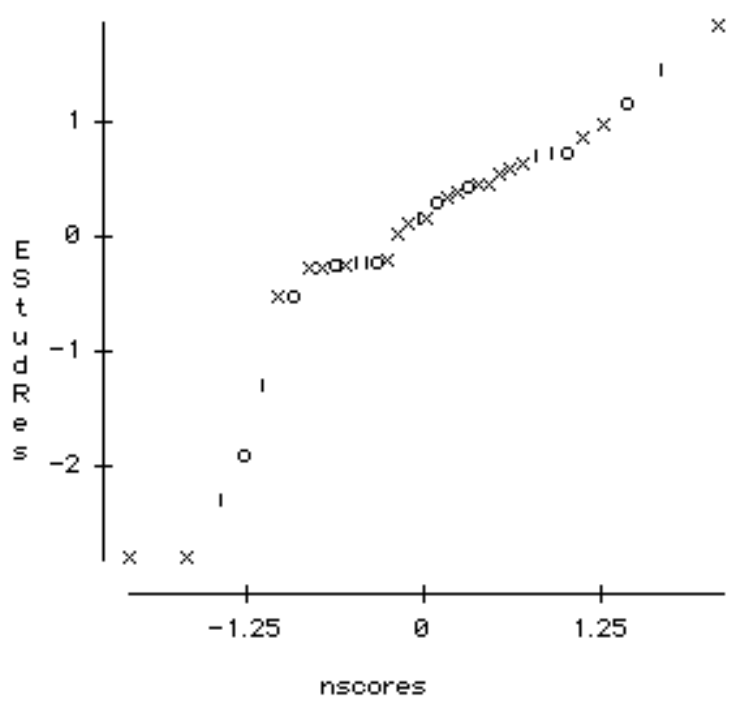

Figure 11f: Residuals for $\log \left(\mathrm{C}_{\text {forehead }}\right)$ 


\section{Effects of Independent Variables on Concentration Values and Ratios of Concentrations}

The effects of the independent variables, on concentrations and ratios of concentrations were analyzed using both normal and log-transformed dependent and independent values. The effect of each variable is discussed below.

The chest concentrations were always higher than the other sampling locations. This falls in line with the findings of Guffey et al ${ }^{(17)}$ on a mannequin study where the chest samples always produced highest concentrations. Malek et al ${ }^{(15)}$ observed that the chest concentrations were higher than the nose concentrations, the average velocity in the breathing zone being $60-80 \mathrm{fpm}$. Cohen $e a^{(9)}$ in which the breathing zone concentrations variations showed that the chest concentrations were higher than the other sampling location concentrations in the breathing zone.

Table V: Regression analyses of non-transformed variables

"p" values from the Regression of non-transformed dependent and independent variables

\begin{tabular}{|l|c|c|c|c|c|c|}
\hline Independent variables & Forehead & Nose & Neck & Left Lapel & Right Lapel & Chest \\
\hline Wind tunnel velocity (fpm) & 0.0001 & 0.0001 & 0.0001 & 0.0001 & 0.0001 & 0.0001 \\
\hline Nose sampling rate (lpm) & $*$ & 0.04 & $*$ & $*$ & $*$ & $*$ \\
\hline Shoulder width (inches) & $*$ & $*$ & 0.04 & $*$ & $*$ & 0.0004 \\
\hline Chest width (inches) & 0.07 & $*$ & $*$ & $*$ & $*$ & $*$ \\
\hline Chest circumference (inches) & $*$ & $*$ & 0.02 & $*$ & $*$ & 0.0012 \\
\hline Chest depth (inches) & $*$ & $*$ & $*$ & $*$ & $*$ & $*$ \\
\hline $\mathrm{R}^{2}(\%)$ & 76.8 & 63 & 76.1 & 58.4 & 46 & 69.1 \\
\hline
\end{tabular}

* denotes that the "p" value was $>0.1$ 
Table VI: Regression coefficients results based on individual non-transformed concentrations

\begin{tabular}{|l|c|l|c|c|l|}
\hline $\begin{array}{l}\text { Dependent } \\
\text { variables }\end{array}$ & $\begin{array}{l}\text { Co } \\
\text { Constant }\end{array}$ & $\begin{array}{l}\text { C1 } \\
\text { Velocity }\end{array}$ & $\begin{array}{l}\text { C2 } \\
\text { Sampling } \\
\text { rate }\end{array}$ & $\begin{array}{l}\text { C3 } \\
\text { Shoulder } \\
\text { width }\end{array}$ & $\begin{array}{l}\text { C4 } \\
\text { Chest } \\
\text { circumference }\end{array}$ \\
\hline Forehead & 10.8 & 0.56 & 0 & 0 & -0.28 \\
\hline Neck & 98.37 & 0.89 & 0 & -1.41 & -1.77 \\
\hline Left Lapel & -2.83 & 0.57 & 0 & 0 & 0 \\
\hline Right Lapel & -1.10 & 0.67 & 0 & 0 & 0 \\
\hline Chest & 269.75 & 1.05 & 0 & -4.4 & -4.35 \\
\hline Nose & 6.16 & 0.57 & -7.5 & 0 & 0 \\
\hline
\end{tabular}

\section{Model:}

Concentration $=\mathrm{Co}+\mathrm{C} 1 *($ Velocity $)+\mathrm{C} 2($ Sampling rate $)+\mathrm{C} 3 *($ Shoulder width $)+\mathrm{C} 4 *($ Chest circumference)

Table VII: "p" values form the Regression analyses of non-transformed independent variables on ratio of individual concentrations at locations to concentration at the nose

\begin{tabular}{|c|c|c|c|c|c|}
\hline $\begin{array}{l}\text { Non-transformed independent } \\
\text { variables }\end{array}$ & $\frac{\text { Forehead }}{\text { Nose }}$ & $\frac{\text { Neck }}{\text { Nose }}$ & $\frac{\underline{\text { Left }}}{\frac{\text { Lapel }}{\text { Nose }}}$ & $\frac{\frac{\text { Right }}{\text { Lapel }}}{\frac{\text { Nose }}{n^{2}}}$ & $\frac{\text { Chest }}{\text { Nose }}$ \\
\hline Wind tunnel velocity (fpm) & 0.14 & 0.05 & 0.0007 & 0.038 & 0.15 \\
\hline Nose sampling rate (lpm) & $*$ & $*$ & 0.04 & $*$ & 0.02 \\
\hline Shoulder width (inches) & $*$ & 0.03 & 0.0086 & 0.05 & 0.0002 \\
\hline Chest width (inches) & * & $*$ & 0.07 & $*$ & $*$ \\
\hline Chest circumference (inches) & * & 0.05 & & * & 0.001 \\
\hline Chest depth (inches) & * & $*$ & & * & * \\
\hline $\mathrm{R}^{2}(\%)$ & 7.5 & 25.6 & 50.7 & 24.2 & 51.6 \\
\hline
\end{tabular}

*denotes that the "p" value was $>0.1$ 
Table VIII: Regression coefficients of non-transformed independent variables on ratio of individual concentrations at locations to concentration at the nose

\begin{tabular}{|l|c|l|l|l|l|}
\hline Dependent variables & $\begin{array}{l}\text { Co } \\
\text { Constant }\end{array}$ & $\begin{array}{l}\text { C1 } \\
\text { Velocity }\end{array}$ & $\begin{array}{l}\text { C2 } \\
\text { Sampling } \\
\text { rate }\end{array}$ & $\begin{array}{l}\text { C3 } \\
\text { Shoulder } \\
\text { width }\end{array}$ & $\begin{array}{l}\text { C4 } \\
\text { Chest } \\
\text { circumference }\end{array}$ \\
\hline Forehead/Nose & 0.76 & 0.004 & 0 & 0 & 0 \\
\hline Neck/Nose & 6.54 & 0.013 & 0 & -0.09 & -0.09 \\
\hline Left Lape1/Nose & 2.94 & 0.009 & 0.23 & -0.02 & 0 \\
\hline Right Lapel/Nose & 1.15 & 0.01 & 0 & -0.02 & 0 \\
\hline Chest/Nose & 16.92 & 0.013 & 0.93 & -0.27 & -0.25 \\
\hline
\end{tabular}

$\underline{\text { Model: }}$ Concentration $=\mathbf{C o}+\mathbf{C} 1 *($ Velocity $)+\mathrm{C} 2 *($ Sampling rate $)+\mathbf{C} 3 *($ Shoulder width $)+\mathbf{C} 4 *($ Chest circumference)

Table IX: "p" values form the Regression results based on individual log-transformed concentrations.

\begin{tabular}{|l|c|c|c|c|c|c|}
\cline { 2 - 8 } \multicolumn{1}{c|}{} & \multicolumn{7}{c|}{ Log of concentration at } \\
\hline $\begin{array}{c}\text { Log-transformed } \\
\text { independent variables }\end{array}$ & Forehead & Nose & Neck & Left Lapel & Right Lapel & Chest \\
\hline Wind tunnel velocity (fpm) & 0.0001 & 0.0001 & 0.0001 & 0.0001 & 0.0001 & 0.0001 \\
\hline Nose sampling rate (lpm) & $*$ & $*$ & $*$ & $*$ & $*$ & $*$ \\
\hline Shoulder width (inches) & $*$ & $*$ & $*$ & $*$ & $*$ & $*$ \\
\hline Chest width (inches) & $*$ & $*$ & 0.01 & $*$ & $*$ & 0.0003 \\
\hline Chest circumference (inches) & 0.01 & 0.02 & $*$ & $*$ & $*$ & 0.001 \\
\hline Chest depth (inches) & $*$ & $*$ & $*$ & $*$ & $*$ & $*$ \\
\hline $\mathrm{R}^{2}(\%)$ & 74.3 & 65.3 & 74.5 & 61.5 & 61.5 & 73.5 \\
\hline
\end{tabular}


Table X: Regression coefficients results based on individual Log-transformed concentrations

\begin{tabular}{|l|l|l|l|l|l|}
\hline Dependent variable & $\begin{array}{l}\text { Co } \\
\text { Constant }\end{array}$ & $\begin{array}{l}\text { C1 } \\
\text { Velocity }\end{array}$ & $\begin{array}{l}\text { C2 } \\
\text { Sampling } \\
\text { rate }\end{array}$ & $\begin{array}{l}\text { C3 } \\
\text { Shoulder } \\
\text { width }\end{array}$ & $\begin{array}{l}\text { C4 } \\
\text { Chest } \\
\text { circumference }\end{array}$ \\
\hline Forehead & 0.98 & 1.02 & 0 & 0 & -0.83 \\
\hline Nose & 1.15 & 0.91 & 0 & 0 & -0.8 \\
\hline Neck & 3.6 & 1.17 & 0 & 0 & 0 \\
\hline Left Lapel & -0.78 & 1.26 & 0 & 0 & 0 \\
\hline Right Lapel & -0.47 & 1.13 & 0 & 0 & 0 \\
\hline Chest & 13.17 & 1.1 & 0 & 0 & 4.27 \\
\hline
\end{tabular}

Model:

Concentration $=10{ }^{\mathrm{C} 0 *}$ Velocity $^{\mathrm{C} 1} *$ Sampling Rate ${ }^{\mathrm{C}} *$ Shoulder $*$ Width $^{\mathrm{C} 3} *$ Chest Circumference $^{\mathrm{C} 4}$

Table XI: Effect of Log-transformed independent variables on ratio of individual concentrations at locations to concentration at the nose.

Log- transformed

\begin{tabular}{|c|c|c|l|l|l|}
\hline $\begin{array}{c}\text { Log-transformed } \\
\text { independent variables }\end{array}$ & $\frac{\text { Forehead }}{\text { Nose }}$ & $\frac{\text { Neck }}{\text { Nose }}$ & $\begin{array}{l}\text { Left } \\
\text { Lapel } \\
\text { Nose }\end{array}$ & $\begin{array}{l}\text { Right } \\
\text { Lapel }\end{array}$ & $\begin{array}{l}\text { Nose } \\
\text { Nose }\end{array}$ \\
\hline Wind tunnel velocity (fpm) & $*$ & 0.01 & 0.008 & 0.1 & 0.004 \\
\hline Nose sampling rate (lpm) & 0.08 & $*$ & 0.03 & $*$ & 0.008 \\
\hline Shoulder width (inches) & $*$ & $*$ & $*$ & $*$ & $*$ \\
\hline Chest width (inches) & $*$ & 0.01 & 0.04 & $*$ & 0.0001 \\
\hline Chest circumference (inches) & $*$ & 0.01 & 0.01 & 0.07 & 0.0001 \\
\hline Chest depth (inches) & $*$ & $*$ & $*$ & $*$ & $*$ \\
\hline $\mathrm{R}^{2}(\%)$ & 10.5 & 35.4 & 44.1 & 19.2 & 73.9 \\
\hline
\end{tabular}

* denotes that the "p" value was $>0.1$ 
Table XII: Regression coefficients based on ratio of Log-transformed concentrations to Nose

\begin{tabular}{|l|l|l|l|l|l|}
\hline $\begin{array}{l}\text { Dependent } \\
\text { variables }\end{array}$ & $\begin{array}{l}\text { Co } \\
\text { Constant }\end{array}$ & $\begin{array}{l}\text { C1 } \\
\text { Velocity }\end{array}$ & $\begin{array}{l}\text { C2 } \\
\text { Sampling } \\
\text { rate }\end{array}$ & $\begin{array}{l}\text { C3 } \\
\text { Shoulder } \\
\text { width }\end{array}$ & $\begin{array}{l}\text { C4 } \\
\text { Chest } \\
\text { circumference }\end{array}$ \\
\hline Forehead/Nose & -0.008 & 0 & 0.08 & 0 & 0 \\
\hline Neck/Nose & 5.13 & 0.26 & 0 & 0 & 1.9 \\
\hline Left Lapel/Nose & 4.17 & 0.35 & 0.17 & 0 & 2.57 \\
\hline $\begin{array}{l}\text { Right } \\
\text { Lapel/Nose }\end{array}$ & -1.35 & 0.22 & 0 & 0 & 0.63 \\
\hline Chest/Nose & 13.09 & 0.18 & 0.16 & 0 & 5.51 \\
\hline
\end{tabular}

Model:

Concentration $=\mathrm{Co}^{*}$ Velocity $^{\mathrm{C} 1} *$ Sampling Rate $^{\mathrm{C} 2} *$ Shoulder $^{*}$ Width $^{\mathrm{C}} *$ Chest $_{\text {Circumference }}{ }^{\mathrm{C}}$

Wind tunnel velocity

As shown in Tables V and IX, wind tunnel velocity was highly significant $(\mathrm{p}=0.0001)$ for all sampling locations, whether the data were log transformed or not. The concentrations at all sampling locations increased with increases in the wind tunnel velocity (see Appendices 8 and 9). This was observed also for the log-transformed and non-transformed ratios of concentration, the only exception being ratio of $\mathrm{C}_{\text {forehead }} \mathrm{C}_{\text {nose. }}$. The regression constants derived from the $\log$ transformed regression coefficients (see Table X) range from 0.91-1.26, suggesting that the effect of the wind tunnel velocity was linear. The low slopes $(0.56$ to 1.05$)$ found for untransformed concentrations ratios (see Table VI), also suggest a substantial effect of velocity for the range tested.

This agrees with some earlier studies (Guffey et al, 2000; Welling et al, 2000) and disagrees with others (Kim and Flynn, 1992). Of these studies, all were with mannequins except (Welling et al, 2000) and (Kim and Flynn, 1992). 


\section{Chest circumference}

As shown in Table $\mathrm{V}$, the effects of chest circumference dimensions were statistically significant $(p=0.02)$ for neck concentrations and highly significant $(p=0.0012)$ for chest concentrations. Interestingly the $\mathrm{C}_{\text {forehead, }}, \mathrm{C}_{\text {nose }}$ and $\mathrm{C}_{\text {chest }}$ declined with increasing chest dimensions as indicated by a negative correlation observed in the regression coefficients for chest circumference (see Table VI).

$(\mathrm{o}=$ Subject no. 1, $\mathrm{x}=$ Subject no.2, $1=$ Subject no. 3$)$

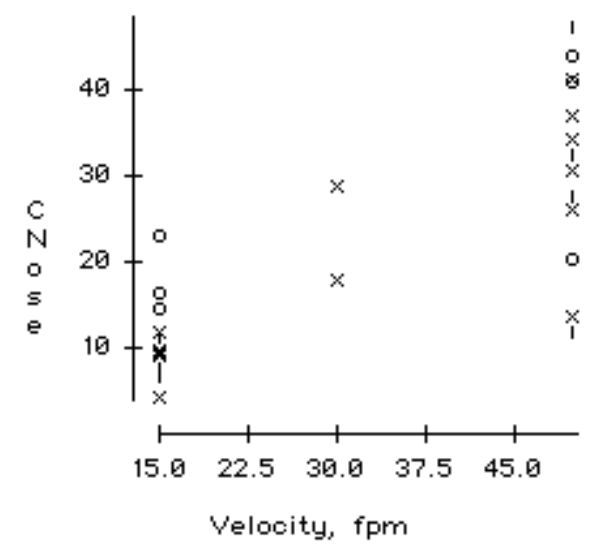

Figure 12a: $\mathrm{C}_{\text {nose }}$ vs. velocity for all subjects

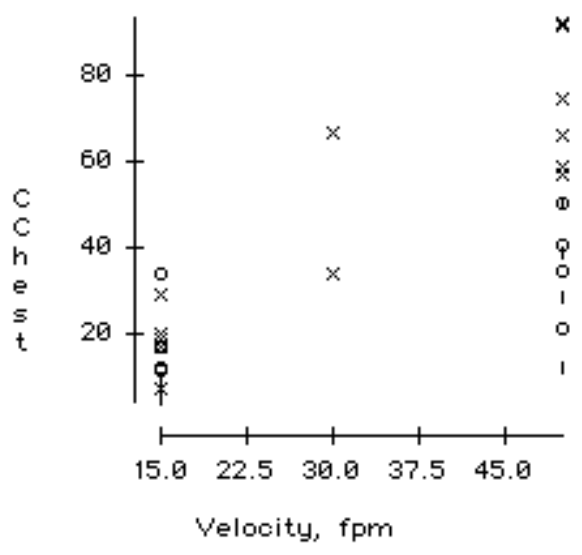

Figure 12b: $C_{\text {chest }}$ vs. velocity for all subjects 
Table IX shows the strong significance $(\mathrm{p}=0.001)$ of the chest circumference for the $\log$ transformed values on the $\mathrm{C}_{\text {chest }}$. The ratio of log-transformed $\left(\mathrm{C}_{\text {chest }} / \mathrm{C}_{\text {nose }}\right)$ reflects a very strong significance (see Table XII) due to the fact that the regression coefficient (log-transformed) was 4.27 (Table X).

The regression coefficients for the log-transformed $\left(\mathrm{C}_{\text {neck }} / \mathrm{C}_{\text {nose }}\right)$ and the $\left(\mathrm{C}_{\text {left lapel }} / \mathrm{C}_{\text {nose }}\right)$ show a relatively high significance 1.9 and 5.51(see Table XII). It is interesting to note that the $\left(\mathrm{C}_{\text {right lapel }} / \mathrm{C}_{\text {nose }}\right)$ also shows a strong significance with the chest circumference (see Table XI), but does not show any correlation on the regression coefficients. This shows that there is an interaction between the log-transformed lapel concentrations and the velocity (see Table XII) as the velocity regression coefficients for $\left(\mathrm{C}_{\text {neck }} / \mathrm{C}_{\text {nose }}\right)$ and $\left(\mathrm{C}_{\text {left lapel }} / \mathrm{C}_{\text {nose }}\right)$ was marginally higher than the log-transformed $\left(\mathrm{C}_{\text {right lapel }} / \mathrm{C}_{\text {nose }}\right)$.

\section{Nose sampling rate}

Adjacent to nose sampling rate was significant for non-transformed concentration ratios of $\mathrm{C}$ (chest/nose), $\mathrm{C}$ (left lapel/nose) and $\mathrm{C}$ (forehead/nose), but there was no significance observed in the regression coefficients for these locations.

The sampling rate was significant only to the nose concentration as one would have expected and results earlier described reconfirm this observation. There is no evidence of studies that confirm this observation, as very few published research is available on the effect of sampling rates on the breathing concentration. Donaldson and Stringer ${ }^{(6)}$ had sampled at $21 \mathrm{pm}$, $1.7 \mathrm{lpm}$ and the US Atomic Energy Commission sampling procedure, by attaching a plastic cassette on the workers lapel, in monitoring of air borne beryllium. The study concluded that there was no correlation between the three sampling methods and that a conversion factor was not possible to be obtained between these sampling methods. Most of the literature reviewed shows the sampling rate in the breathing zone was $1.7 \mathrm{lpm}$ with real time monitoring being conducted. 


\section{Chest depth and shoulder width}

As one would have expected the $\mathrm{C}_{\text {neck }}$ (see Table V), was affected by the shoulder width ( $\mathrm{p}=$

0.04), but the regression coefficient (see Table VI) indicated that as the shoulder width increases the $\mathrm{C}_{\text {neck }}$ decreases. A similar pattern was noted for $\mathrm{C}_{\text {chest}}$, where the regression coefficient for shoulder with was (-4.35) which means that $\mathrm{C}_{\text {chest }}$ would decrease with increasing shoulder width. The chest depth showed no significance on any of the sampling location concentrations. 


\section{Conclusions}

The results of this study strongly support the following conclusions for the conditions studied:

1. Concentrations at sampling locations increased with increases in cross draft velocities.

2. The chest concentrations were the highest amongst all flowed by the neck and nose. Increase in the chest circumference and shoulder width decreases the $\mathrm{C}_{\text {chest }}$.

3. The sampling rate affected only $\mathrm{C}_{\text {nose }}$, and at no other location.

4. $\mathrm{C}_{\text {chest }}$ and $\mathrm{C}_{\text {neck }}$ values varied substantially among subjects.

5. The $\mathrm{C}_{\text {neck }}$ decreased with increasing shoulder width.

6. These results apply to the velocities and conditions studied. They should not be applied to velocities beyond the range of the study. Likewise, the effects of body dimensions may be different for subjects whose dimensions are beyond the ranges of those studied here.

\section{Caveats and Limitations}

This study was done in a wind tunnel with airflows far more uniform than would exist in a work place or in most spray booths. Future studies should consider less uniform flows, also. Only 3 subjects were tested, and it is possible that results would prove different for a broader array of human subjects. Future studies should be done with a diverse range of body shapes and sizes. This study was done with one, non-energetically performed task done by a subject sitting at a table. It is possible that results would differ for standing subjects or for subjects doing different tasks. 


\section{References}

1. Kim, T. and Michael R. Flynn.: Airflow Pattern around A Worker in a Uniform Freestream. Am Ind Hyg.Assoc.J.52: 287-296 (1991).

2. Flynn, M.R. and Dennis K.George.: A Filed Evaluation of a Mathematical Model to Predict Worker Exposure to Solvent Vapors. Appl.Occup.Environ.Hyg. 11(10): 12121216; (1996).

3. www.osha.gov :OSHA Technical Manual Section II: Chapter 1, General; II.Sampling procedures, Starting Sampling. Dated 03/31/2003

4. Cohen, B.S.; Harley, N.H.; Lippman, M.: Bias in Air Sampling Techniques Used to Measure Inhalation Exposure. Am Ind Hyg.Assoc.J.44: 187-192 (1984).

5. Chatterjee, B.B., M.K. Williams, J. Walford and E. King: The Location of Personal Samplers Filter Heads. Am.Ind Hyg.Assoc.J.30: 643-645 (1969).

6. Donaldson, H.M. and W.T. Stringer: Beryllium Sampling Methods.: Am Ind Hyg.Assoc.J.41: 85-90 (1980).

7. Martenelli, C.A.; Harley, N.H.; Cohen, B.S.: Monitoring Real-time Aerosol Distribution in the Breathing Zone. Am Ind Hyg.Assoc.J.44: 280-285 (1983).

8. Van Der Wal, J.F.; Moerkerken, A.: The Performance of Passive Diffusion Monitors for organic Vapors for Personal Sampling of Painters. Ann.Occup.Hyg. 28: 39-47 (1984).

9. Cohen, B.S.; Malek R.: Measurement of Workers Exposure to Styrene. Final Report. NIOSH-00182755.Grant No. 1 RO3 OHO2180.

10. Kim, T. and Michael R. Flynn.: The Effect of Contaminant Source Momentum on a Workers Breathing Zone Concentration In a Uniform Freestream. Am Ind Hyg.Assoc.J.53: 757-766 (1992).

11. Rodes, C.E., Kamens, R.M., Wiener, R.W.: Experimental Consideration for the Study of Contaminant Dispersion near the Body Am Ind Hyg.Assoc.J.56: 535-545 (1995).

12. Kulmala, I., Saamanen, A., Enbom, S.: The Effect of Contaminant Source Location on Worker Exposure in the Near-Wake Region. Ann.Occup.Hyg. 40: 511-523 (1996).

13. Johnson, A.E., Fletcher, B., Saunders, C.J.: Air Movement Around a Worker in a LowSpeed Flow Field. Ann.Occup.Hyg. 40: 57-64 (1996). 
14. Flynn, M.R., and Bengt Ljungqvist: A Review Of Wake Effects On a Workers Exposure. Ann.Occup.Hyg. 39: 211-221 (1995).

15. Malek, R.F., Daisy, J.M., Cohen, B.S.: Breathing Zone Concentrations Variations in the Reinforced Plastic Industry; Field measurements in a Boat Manufacturing Plant. Appl.Occup.Environ.Hyg. 14(11): 777-784; (1996).

16. Welling, I., Andersson, I., Rosen, G., Raisanen, J., Mielo, T., Marttien, K., Niemela, R.: Contaminant Dispersion in the Vicinity of a Worker in a Uniform Velocity Field. Ann.Occup.Hyg. 44: 219-225 (2000).

17. Guffey, S. E., Flanagan, M.E., Belle van G.: Air Sampling at the Chest and Ear as Representative of the Breathing Zone. Am Ind Hyg.Assoc.J.62: 416-427 (2001).

18. Space craft Maximum Allowable Concentrations for Selected Airborne Contaminants: Volume 3(1997) www.nap.edu/openbook/0309056292/html/171-199 dated 03/31/2003.

19. Bisesi, M.S., Kohn, J.P. Industrial Hygiene Evaluation Methods, 2000.

20. Plog, B.A., Niland, J., Quinlan, P.J.: Fundamentals of Industrial Hygiene, 4th Edition. National Safety Council. 


\section{Appendix 1}

\section{Equipments}

\subsection{Wind tunnel}

A wind tunnel 9'x12'x40' was constructed (see Figure Appendix 1.1 and 1.2). High Efficiency Particulate Air (HEPA) filters, (American Air Filters, AstroCel I ${ }^{\circledR}$ ) were installed at the inlet to stream line the incoming flow of air. At the back end of the wind tunnel another type of filtering media (Perfect Pleat ${ }^{\circledR}$ ) was installed in front of the carbon molecular sieves. A fan was installed to suck the air into the wind tunnel and through the filtering media. The rotational speed of the fan was adjusted on the control panel located on the right side of the wind tunnel.

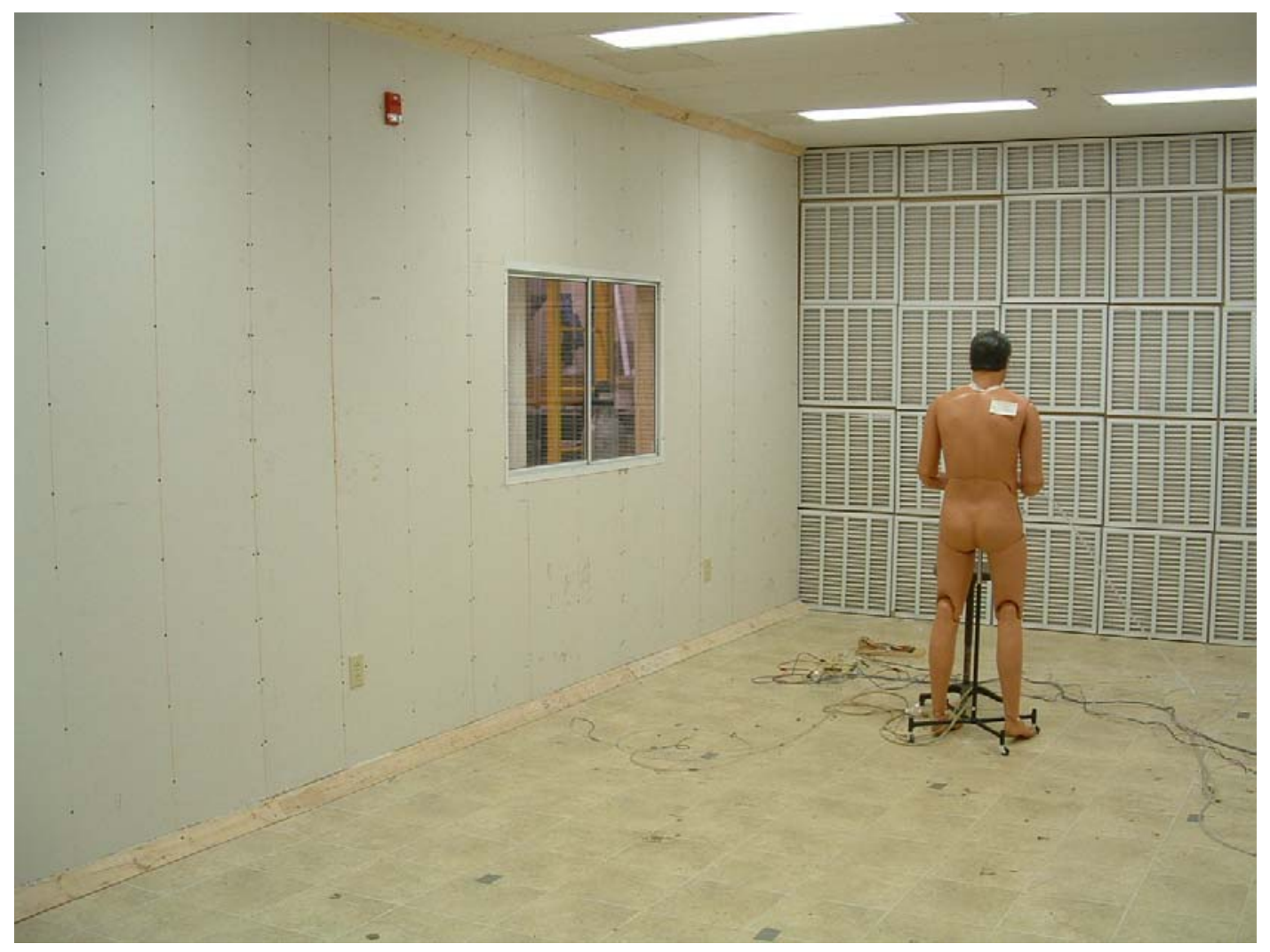

Figure Appendix 1.1 Wind tunnel with mannequin. 


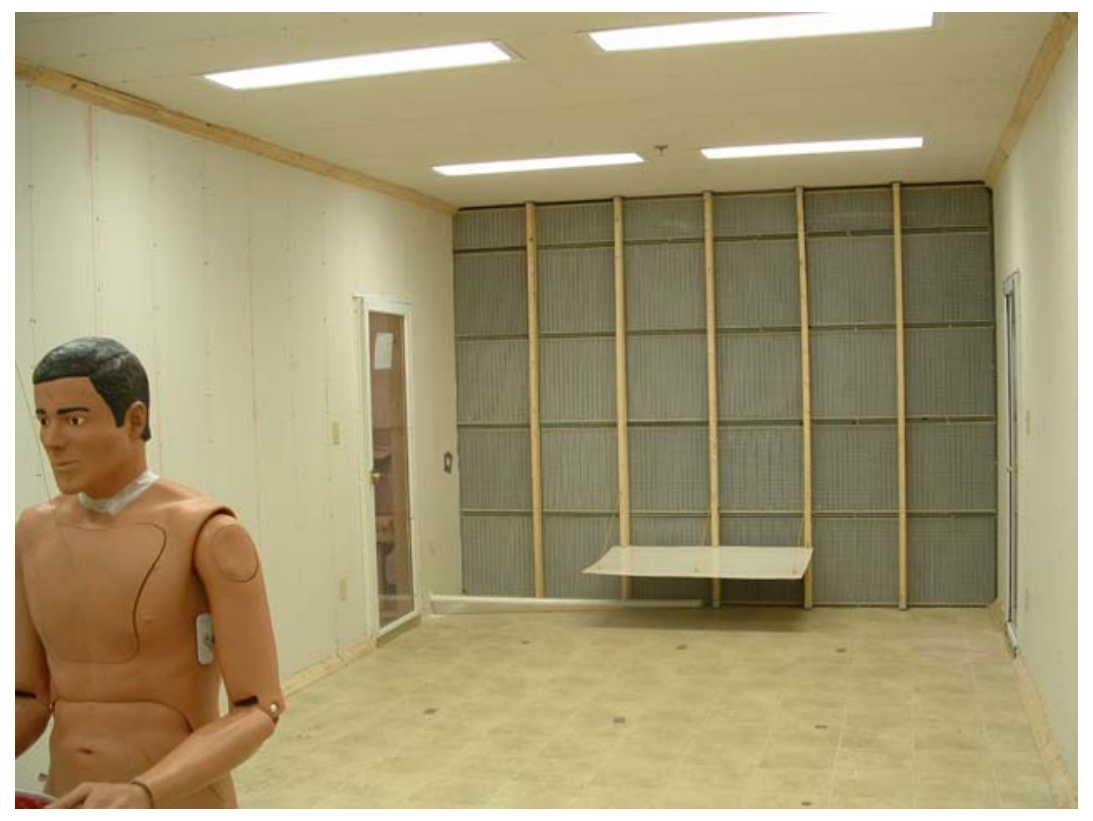

Figure Appendix 1.2 Front view of the Wind tunnel with mannequin.

\subsection{Gas Chromatograph}

A PE Photovac (Model Voyager, S/N: EV-FD-209) Portable Gas chromatograph (GC), (see Figure Appendix 2.1) was used to identify airborne chemicals and measure their concentrations. GC Operation: (from GC manual)

The Voyager draws a sample of air and automatically injects onto the sample column. The Voyager manages the gas flows and timing during the analysis; and compares the outcome of the analysis against previous analyzed calibration standard. The Voyager then reports the analysis results on its display by compound and concentration and stores the analysis results in its internal data logger. 


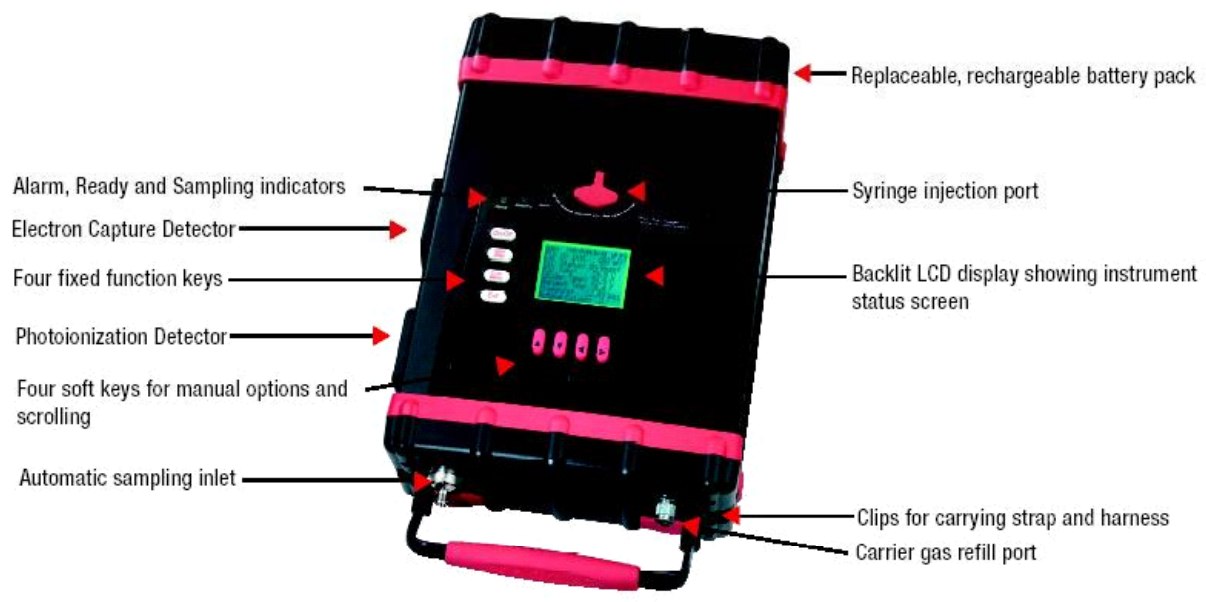

Figure Appendix 2.1:Gas Chromatograph

\subsection{Technical description}

The Voyager uses gas chromatography to separate and detect volatile organic compounds (VOCs) present in an air sample.

In a $\mathrm{GC}$, the sample is carried from the point of introduction, through a separating column, and then out through a detector, by a continuous stream of relatively inert gas. The column in a GC is a long tube with sorptive material coating the inside walls or packed into the tube. The sample components become separated from one another as they are carried through the column because of the differences in their rates of interaction with the sorptive material. Each different sample component is therefore retained for a different length of time within the column, and elutes from the column into the detector at a characteristic retention time.

The photo ionization detector responds as each component flows through the detector cell. If the detector response is displayed against the elapsed time, then series of peaks separated in the time are seen, one peak for each sample component. The retention time of the tip of each peak indicates what the sample component is, and the area of the peak indicates how much is present. 
Chromatography is a comparative technique of analysis. The identities and concentrations reported by Voyager after a sample is analyzed are based on the retention times and the peak sizes of previously analyzed standards. When an assay is set up in the Voyager, a standard of each compound can be stored in the Voyager's memory by retention time, peak area, and concentration. The ratio of peak area to concentration is the sensitivity (the response to concentration ratio, measured in (mVS/ppm) for the compound. This information is saved in a part of Voyagers memory called the "library", and automatically updated during a calibration. In each sample analysis, peak retention times are compared to the retention times of library compounds. If they match (within the limits of the peak recognition window), then the peak is identified as the corresponding library compound. To calculate the identified peak, its area is divided by the library sensitivity for the compound. Library retention times and sensitivities are updated whenever the Voyager is calibrated. Voyager also calculates the new retention time to old retention time ratio for each library compound in the calibration gas. If a library compound is not present in the calibration gas, Voyager updates its retention time by multiplying it by an average calculated from compounds in the calibration gas.

Sample introduction: Samples can be introduced into a GC either manually or automatically. Voyager accepts air and gas samples either ways. Automatic sample injection is the easiest means of introduction. This is done using Voyager's internal sampling pump and sample loop. When the sample pump is on, the sample is drawn through in through the Voyagers sample in port, and then through a fixed volume called a sample loop, then through the pump to be vented through the pump outlet port. The sample loop has gas-switching valves at the either end. Once the sample loop is full of sample gas, the pump stops and these valves switch to connect one end of the loop to the carrier gas supply and the other end of the loop to the beginning or head of the GC column. Carrier gas then sweeps the sample from the loop onto the column for analysis. Once the sample has been injected, the carrier gas flow is again switched, this time to bypass the loop and continue to the feed column. 


\subsubsection{Precolumn back flushing}

After the analysis of the first sample, if the second sample is introduced onto the GC column before the first analysis is completed, it is possible for retained components in the second sample to flow through the detector at the same time as longer-retained components in the first sample. This leads to difficulty in interpreting the detector input signal. Precolumn back flushing reduces total analysis time in the Voyager, and also increases the analytical confidence by reducing the possibility of peaks from an earlier analysis eluting during a later analysis.

GC columns are used to separate the type of gas to be analyzed, form the others. A Photo ionization detector (PID) is used to analyze the concentration of the gas to be analyzed. The ionized molecules in the PID generate an electric current in an electric field that is proportional to the concentration of the ionized molecules.

For the GC analysis, the Site chart LX version 1.21 was used.

\subsection{Respitrace Plus ${ }^{\circledR}$}

Respitrace Plus ${ }^{\circledR}$ (Non Invasive Monitoring Systems, Model no. SY07, Serial no.1211) is a selfcalibrating, stand-alone, portable system designed to monitor the human breathing rate (Figure Appendix 3.1 and 3.2). Sensing rib cage and abdominal components of breathing using Respiband ${ }^{\circledR}$ placed around the subject's ribcage and abdomen determines breath function. The Respiband ${ }^{\circledR}$ are connected to a common subject cable that plugs into the front panel of the Respitrace Plus. Investigator developed software and electronic circuit are used to separate the signals of inhalation and exhalation; and control operation of the "inhalation" and "exhalation" pumps.

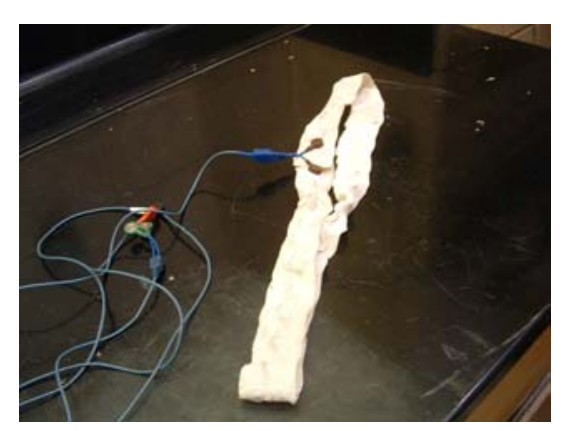

Figure Appendix: 3.1 Respiband 


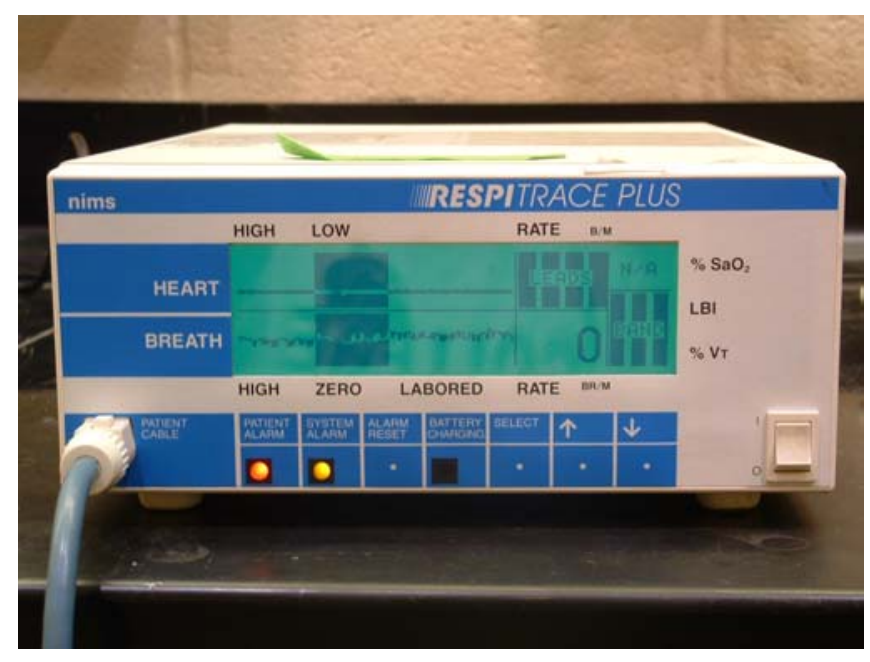

Figure Appendix: 3.2 Respitrace Plus 


\subsection{Rotameter}

To measure the nitrogen flow, a pre calibrated Cole Parmer ${ }^{\circledR}$ rotameter (S/N A-03234-13) was used. The rotameter has two floats, (black glass and stainless steel) for better accuracy. The operating range for air was $0.2-20 \mathrm{lpm}$, and pre calibrated by the manufacturer. Investigator corrected for nitrogen, as the calibration made by the manufacturer was determined for air. The inlet of the rotameter was connected to the nitrogen supply from the cylinder and its outlet to the inlet of the mixing chamber.

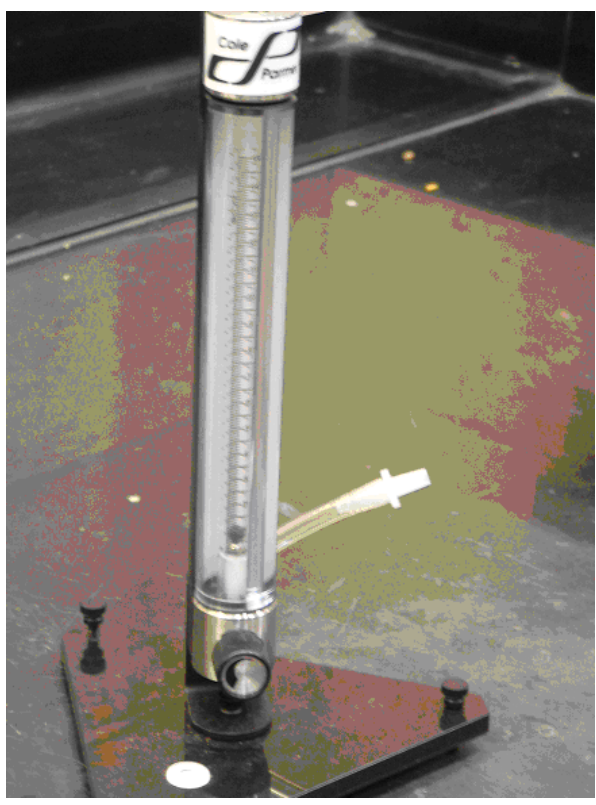

Figure Appendix: 4.1 Rotameter 


\subsection{Sampling bags}

Teflon sampling bags (Jensen) were used to collect sampled air. The capacity of the Teflon bags was 3 liters. The Teflon bags had a fitting at the center of the bag. The fitting is comprised of a septa and a stem (Figure Appendix 5.1). When collecting the sample the stem has to be pressed downwards and turned in the anticlockwise direction to open it. After the sample is collected the stem is pulled and turned in a clockwise direction to close it. Each bag was checked for leaks prior to use.

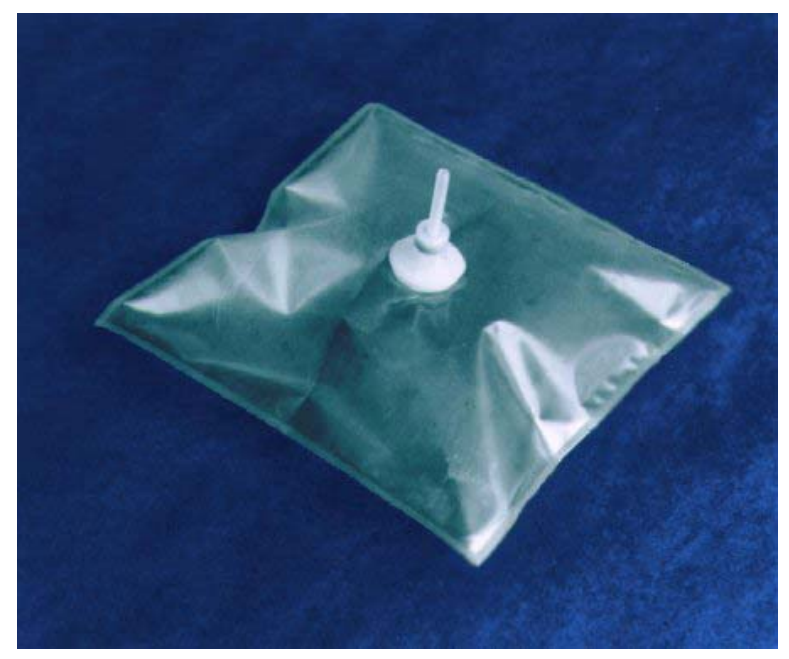

Figure Appendix: 5.1 Teflon sampling bag 


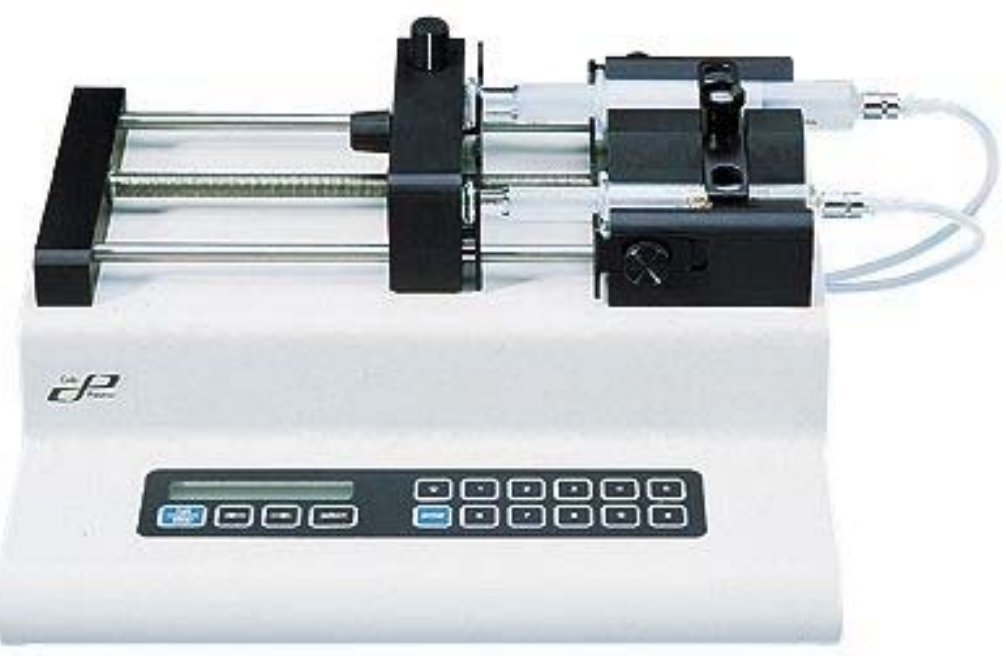

Figure Appendix: 6.1 Syringe pump used to inject ethanol liquid

A Cole-Parmer syringe pump, model EW-74900-10, (infusion type) syringe pump was used for the experiments (Figure Appendix 6.1). The ESP (ethanol syringe pump) has two notches to hold two syringes. One or both syringes can be used at a time. One Cole-Parmer $50 \mathrm{ml}$ syringe EW74040-20, (Figure Appendix 6.2) was used for the experiments. The manufacturer's operation manual was referred to prior to using the ESP for the experiments.

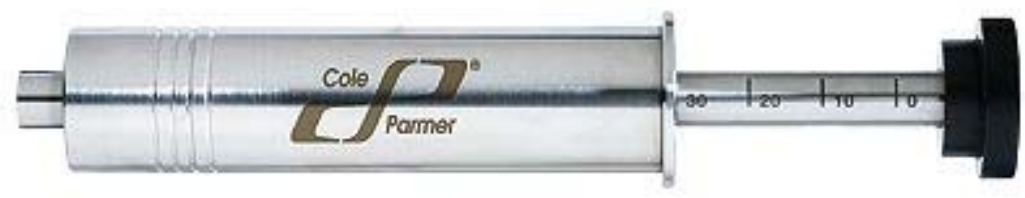

Figure Appendix: 6.2 Ethanol Syringe 


\subsection{Mixing chamber}

A mixing chamber (Figure Appendix 7.1) was custom-designed to ensure mixing of the ethanol vapor and nitrogen. The mixing chamber was of a small glass beaker placed inside half a gallon glass jar. There were 3 openings for the large ethanol syringe pump, and the third one for the mixture of the ethanol gas and nitrogen, which would eventually be the source line. There was a resistor that was placed inside the small glass bottle. The jar was penetrated by two connectors for Teflon tubes and by one connected for $1 \mathrm{~mm}$ I.D.; copper tubing, connected to the $50 \mathrm{ml}$ syringe. Liquid ethanol ejected a fixed rate from the syringe pumped dripped (roughly 1 drop every 5 seconds) onto an 8-ohm resistor partially wrapped in aluminum foil.

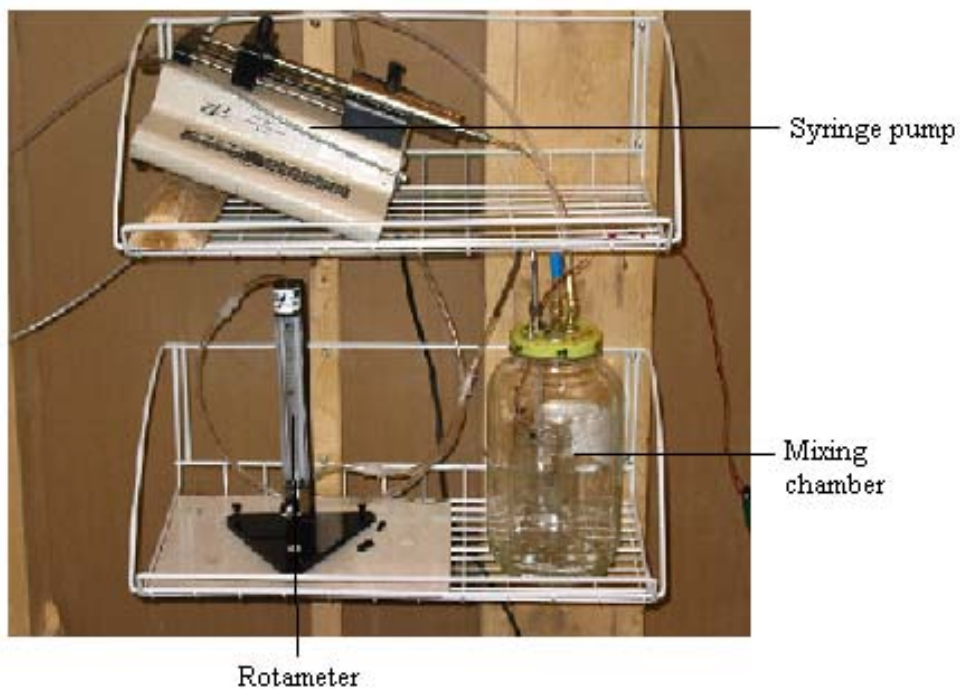

Figure Appendix: 7.1 Experimental set-up 


\subsection{High flow pumps}

When tests called for $1 \mathrm{lpm}$ sampling rate at the nose, SKC Model 224-PCXR4 (Figure Appendix 8.1) were used for sampling, the Nose site at $1 \mathrm{lpm}$. The manufacturers manual was used which was supplied along with the equipment prior to use the High flow pumps were calibrated. The pump was calibrated with a "Dry-Cal"(BIOS model- DCL5K, and S/N 1617) airflow calibrator prior to use.

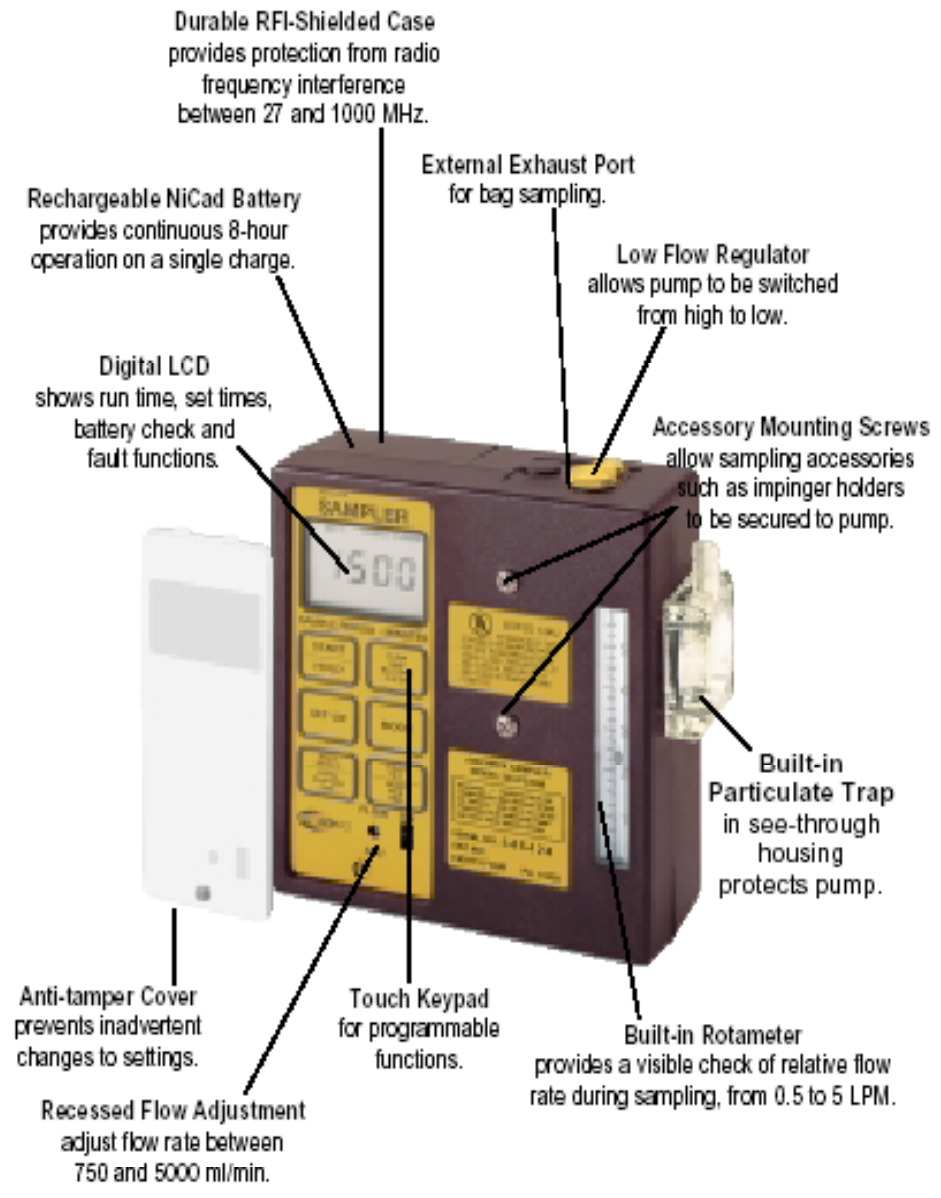

Figure Appendix 8.1 High flow Pump 


\subsection{Low flow sampling pumps}

Low flow sampling pumps, SKC, Model 222-3 (Figure Appendix 9.1) were used for all samples except those taken with the high flow pump. The flow range for these pumps was 50-200 $\mathrm{ml} / \mathrm{min}$. The Low flow sampling pumps had an "ON/OFF" switch, to start and stop the pump. The dial on the face of the pump was used to set the flow rate. Each of the Low flow sampling pumps had a stroke count displayed on the pump. The pumps used for inhalation and exhalation were modified and each pump had two wires which when connected with a switch would start the pump. The low flow sampling pumps were charged for at least 6 hours prior to use and were calibrated with a "Dry-Cal" BIOS model- DCL 5K, and S/N 1617.

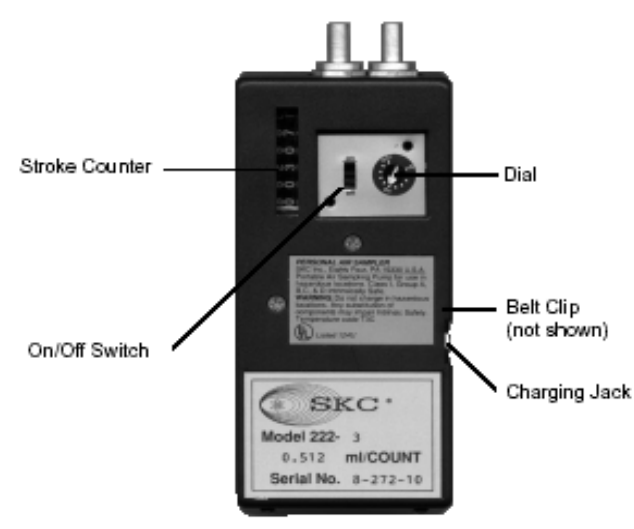

Figure Appendix: 9.1 SKC Low flow sampling pump 


\subsection{Large volume manual syringe (calibration syringe)}

A 3-Liter syringe (PDS, S/N-SY01377) was used to introduce known volumes of air inside the Teflon bags and to remove the air later. The manual syringe had a plunger at one end and open port at the other. The plunger had pre-calibrated marking from 0-3 liters in $100 \mathrm{ml}$ increments. Pulling out the plunger drew in ambient air.

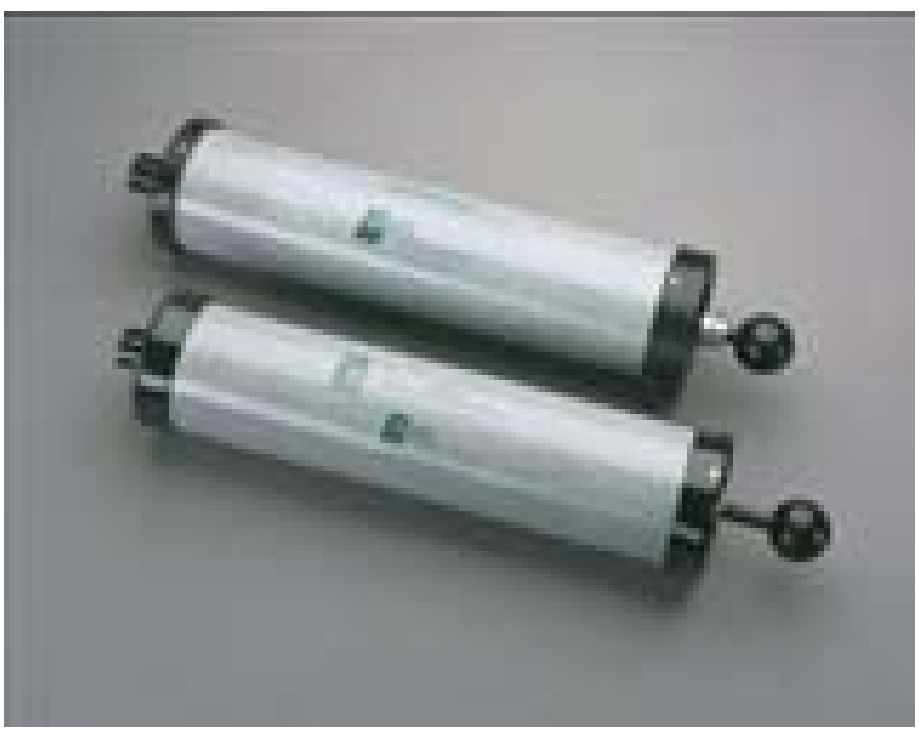

Figure Appendix: 10.1 Manual syringe 


\subsection{Barometer}

Princo Instruments Inc barometer, model no.453 X was used to measure the barometric pressure. The barometer was mounted outside the wind tunnel at the rear. The mounting instructions and the operating procedures were followed as stated by the manufacturer.

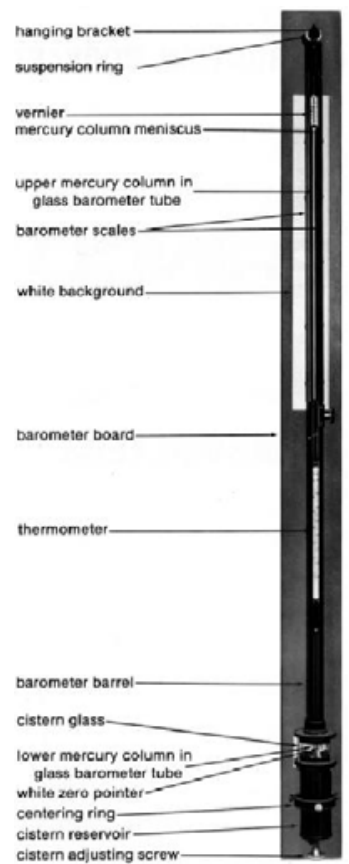

Figure Appendix: 11.1 Fortin type mercurial barometer 


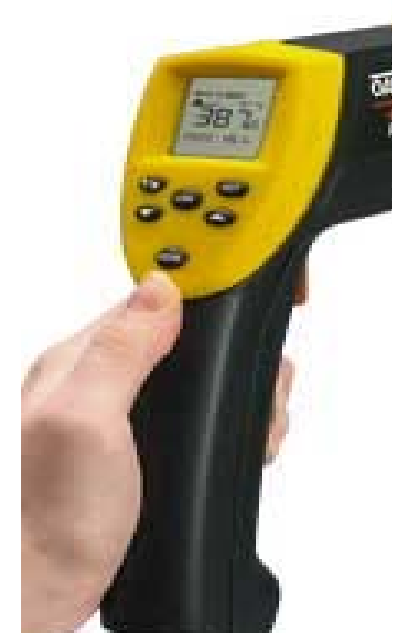

\section{Figure Appendix: 12.1 Oakton infrared thermometer}

A digital thermometer (OAKTON, model WD-35629-00) was used to measure the temperature inside the wind tunnel. Infrared thermometers measure the surface temperature of an object. The unit's optics sense emitted, reflected, and transmitted energy; which is collected and focused onto a detector. The unit's electronics translate the information into a temperature reading, which is displayed; on the unit. A laser is used for aiming purposes only. To measure the temperature the unit was pointed at an object, and the trigger was held. The digital thermometer has a scale in Fahrenheit and degrees Celsius. LCD readout can be switched to Fahrenheit or Celsius. 


\subsection{Carbon dioxide monitor}

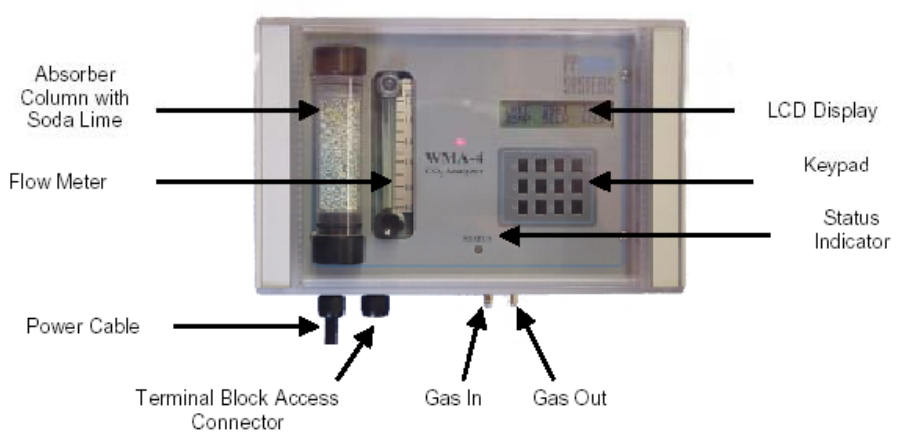

\section{Figure Appendix: 13.1 Carbon dioxide monitor}

The WMA-4 CO2 Analyzer was used to measure the carbon dioxide content exhaled by the human subject form the Teflon bag. It is designed to operate from 115-230V AC power. It is a high precision analyzer for use in monitoring/controlling $\mathrm{CO} 2$ in greenhouses, environment control rooms, nurseries and industrial applications.

The WMA-4 CO2 is a non-dispersive, infrared gas analyzer that features an "Auto-Zero" facility. Using infrared gas analysis techniques, we can readily determine CO2 (Carbon Dioxide) concentrations to within a few ppm according to the manufacturer. Gases with di-atomic molecules such as $\mathrm{CO} 2$ strongly absorb photons in the infrared range. For $\mathrm{CO} 2$, one region of strong absorption is 4.26 microns. A source emitting strongly at this wavelength is a light bulb. If this is positioned at one end of a tube and at the other end is placed a sensor that is sensitive to photons at 4.26 microns, we have a simple infrared gas analyzer. As carbon dioxide is passed down the sample cell, it absorbs some of the infrared and the sensor reading decreases. 


\subsection{Dry-cal}

A primary standard Dry Cal, BIOS model- DCL5K, and S/N 1617, (Figure Appendix 14.1) was used to calibrate the low flow pumps and the high flow pumps. This instrument is a direct reading type and displays the volume sampled by the instrument to be calibrated (in our case, sampling pumps). An average of 10 readings was considered as representative one.

From the Dry Cal manual:

"The Dry Cal DC-Lite can be used for measuring air flow rates for either a pumping flow source (in the suction mode) or for either regulated bottled gas or other types of pressure flow sources (in the pressure mode). Unit in the suction mode the pump should be connected to the outlet port (the lower air boss). As a reading is initiated (by pressing the $<$ READ $>$ button) the cell valve closes and the pump or flow source evacuates or pressurizes the air in the flow-measuring cell. The piston rises at the rate of evacuation or pressurization. A precision laser etched encoder system provides two finely collimated light beams with a known distance between the beams. After a suitable acceleration interval the piston breaks the light beams as it passes. The flow reading is completed when the second beam is broken and a crystal clock measures the time between the two breaks. The computer then opens the valve and the piston resets. The flow measurement is instantly displayed on the LCD in milliliters per minute $(\mathrm{ml} / \mathrm{min})$ or liters per minute (lpm)."

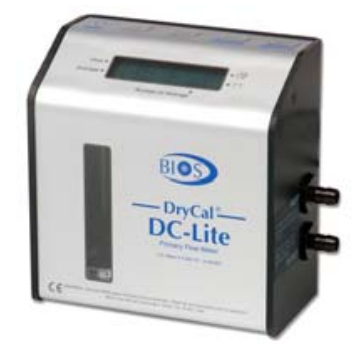

Figure Appendix: 14.1 Dry-Cal ${ }^{\circledR}$ DCL5K 


\subsection{Sling psychrometer}

A sling psychrometer was used to measure the relative humidity inside the wind tunnel. The sling psychrometer has a dry bulb and a wet bulb and the later has a wick, which is wrapped around it. Prior to measuring the wick was wetted with distilled water. The difference in the dry bulb and the wet bulb was noted. The relative humidity was then calculated with the scale that came along with the equipment, which directly showed the percent relative humidity (\%RH).

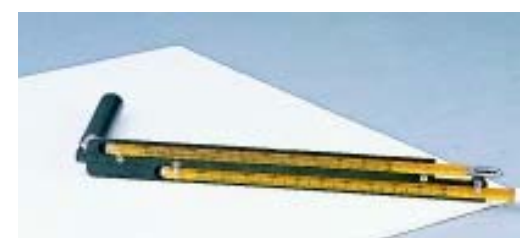

Figure Appendix: 15.1 Sling psychrometer 


\subsection{Airtight container}

An airtight container was used to sample the nose location at $1 \mathrm{lpm}$. The airtight container was selected in such a way that the high flow pump would fit into it. There were 2 openings that were drilled on the lid of the container, one for the inlet from the high flow pump and the second one to connect to the sampling bag. A small length of Tygon ${ }^{\circledR}$ tube was connected between the high flow pump outlet and the sample inlet line, from inside. The integrity of the air-tight container was checked for leaks, prior to start of each experiment. This was done because this pump does not have an exhaust port. 


\section{Appendix 2}

Low flow, High flow sampling pump calibration procedure

Aim: To calibrate the low flow and high flow sampling pump using the primary calibration method.

Table XIII: Apparatus required for calibration of sampling pumps

\begin{tabular}{|c|c|c|c|c|}
\hline Equipment & Manufacturer & Model & $\begin{array}{l}\text { Maximum } \\
\text { Flow rate }\end{array}$ & $\begin{array}{l}\text { Serial } \\
\text { number }\end{array}$ \\
\hline & & & $\begin{array}{l}\text { (lpm) Liters } \\
\text { per minute }\end{array}$ & \\
\hline $\begin{array}{l}\text { Low flow } \\
\text { pump }\end{array}$ & $\mathrm{SKC}$ & $222-3$ & 0.2 & $\begin{array}{l}02-172- \\
15\end{array}$ \\
\hline Dry Cal & DC Lite & $\begin{array}{l}\text { DCL-ML- } \\
\text { Rev.1.08 }\end{array}$ & 5 & 1617 \\
\hline $\begin{array}{l}\text { Tygon tubing } \\
\text { (2 feet) }\end{array}$ & Cole-Parmer & R-3603 & NA & NA \\
\hline
\end{tabular}

Method

1. The sampling pump was charged with the charger for 6 hours.

2. Dry-Cal was charged for 12 hours.

3. The sampling pump was allowed to operate for 5 minutes prior to calibrating.

4. The pump outlet (only in case of Low flow sampling pump) was connected to the inlet of the Dry-Cal, with the Tygon tubing.

5. The arrow on the dial of the Low flow pump was turned to 10.

6. An average of 10 readings was obtained. 
Table XIV: Calibrated readings of sampling pumps

\begin{tabular}{|l|l|c|l|l|l|}
\hline Pump type & \multicolumn{1}{|c|}{$\begin{array}{c}\text { Pump } \\
\text { number }\end{array}$} & $\begin{array}{c}\text { Pre } \\
\text { sampling } \\
\text { calibration } \\
\text { flow rate } \\
\text { (lpm) }\end{array}$ & & & $\begin{array}{c}\text { Average } \\
\text { Flow rate } \\
\text { (lpm) }\end{array}$ \\
\hline Make & SKC & F1 & F2 & F3 & Favg \\
\hline $\begin{array}{l}\text { Low flow } \\
\text { pump }\end{array}$ & $02-175-07$ & 0.15 & 0.1 & 0.15 & 0.15 \\
\hline & $02-175-04$ & 0.16 & 0.1 & 0.15 & 0.15 \\
\hline & $02-057-13$ & 0.14 & 0.1 & 0.16 & 0.15 \\
\hline & $02-121-02$ & 0.16 & 0.1 & 0.16 & 0.16 \\
\hline & $02-172-15$ & 0.15 & 0.1 & 0.16 & 0.15 \\
\hline & $02-121-03$ & 0.15 & 0.1 & 0.16 & 0.16 \\
\hline & $02-057-09$ & 0.15 & 0.1 & 0.15 & 0.15 \\
\hline & $02-121-01$ & 0.16 & 0.1 & 0.14 & 0.15 \\
\hline & $02-057-08$ & 0.16 & 0.1 & 0.16 & 0.16 \\
\hline High flow & $02-175-10$ & 0.15 & 0.1 & 0.15 & 0.15 \\
\hline pump & 562388 & 1.02 & 1 & 1 & 1.01 \\
\hline & 562843 & 1.1 & 1.1 & 1 & 1.07 \\
\hline & 511847 & 1.1 & 1 & 1 & 1.03 \\
\hline
\end{tabular}


Table XV: Calibration data form for sampling pumps

\begin{tabular}{|l|l|l|l|}
\hline $\begin{array}{l}\text { Location of } \\
\text { calibration }\end{array}$ & MRB 242 & Date of calibration & 25-February 2003 \\
\hline Calibrated by & Santosh Kulkarni & Time & $9.00 \mathrm{am}$ \\
\hline $\begin{array}{l}\text { Calibration } \\
\text { instruments }\end{array}$ & Dry-cal & Relative humidity & $74 \%$ \\
\hline $\begin{array}{l}\text { Air sampling } \\
\text { pumps }\end{array}$ & SKC & Calibration done for & $\begin{array}{l}\text { Conducting } \\
\text { experiments }\end{array}$ \\
\hline
\end{tabular}


Table XVI: Sampling Pumps used for the experiments

\begin{tabular}{|l|c|c|}
\hline & Date: 25 Feb 2003 & \\
\hline Nose & High Flow pump serial number & Low Flow pump serial number \\
\hline Neck & SKC 562388 & 5 \\
\hline RLapel & N/A & 8 \\
\hline LLapel & N/A & 7 \\
\hline Inhalation & N/A & 6 \\
\hline Exhalation & N/A & 1 \\
\hline Forehead & N/A & 4 \\
\hline Chest & N/A & 9 \\
\hline
\end{tabular}

\begin{tabular}{|c|c|c|}
\hline & Date: 27 Feb 2003 & \\
\hline & High Flow pump serial number & Low Flow pump serial number \\
\hline Nose & N/A & 3 \\
\hline Neck & N/A & 8 \\
\hline RLapel & $\mathrm{N} / \mathrm{A}$ & 10 \\
\hline LLapel & N/A & 4 \\
\hline Inhalation & N/A & 6 \\
\hline Exhalation & N/A & 1 \\
\hline Forehead & N/A & 7 \\
\hline \multirow[t]{3}{*}{ Chest } & N/A & 9 \\
\hline & Date: 28 Feb 2003 & \\
\hline & High Flow pump serial number & Low Flow pump serial number \\
\hline Nose & SKC 562388 & 8 \\
\hline Neck & N/A & 10 \\
\hline RLapel & N/A & 3 \\
\hline LLapel & N/A & 5 \\
\hline Inhalation & $\mathrm{N} / \mathrm{A}$ & 1 \\
\hline Exhalation & N/A & 6 \\
\hline Forehead & $\mathrm{N} / \mathrm{A}$ & 7 \\
\hline Chest & N/A & 9 \\
\hline
\end{tabular}


Table XVI: Sampling Pumps used for the experiments (continued)

\begin{tabular}{|c|c|c|}
\hline & Date: 4 March 2003 & \\
\hline & High Flow pump serial number & Low Flow pump serial number \\
\hline Nose & SKC 562843 & 3 \\
\hline Neck & N/A & 8 \\
\hline RLapel & N/A & 10 \\
\hline LLapel & N/A & 9 \\
\hline Inhalation & N/A & 6 \\
\hline Exhalation & N/A & 1 \\
\hline Forehead & N/A & 4 \\
\hline \multirow[t]{3}{*}{ Chest } & N/A & 7 \\
\hline & Date: 6 March 2003 & \\
\hline & High Flow pump serial number & Low Flow pump serial number \\
\hline Nose & SKC 511847 & 4 \\
\hline Neck & N/A & 9 \\
\hline RLapel & N/A & 7 \\
\hline LLapel & N/A & 8 \\
\hline Inhalation & N/A & 1 \\
\hline Exhalation & $\mathrm{N} / \mathrm{A}$ & 6 \\
\hline Forehead & N/A & 10 \\
\hline \multirow[t]{3}{*}{ Chest } & N/A & 1 \\
\hline & Date: 7 March 2003 & \\
\hline & High Flow pump serial number & Low Flow pump serial number \\
\hline Nose & SKC 562843 & 7 \\
\hline Neck & N/A & 10 \\
\hline RLapel & N/A & 4 \\
\hline LLapel & N/A & 2 \\
\hline Inhalation & N/A & 6 \\
\hline Exhalation & N/A & 1 \\
\hline Forehead & N/A & 8 \\
\hline Chest & N/A & 5 \\
\hline
\end{tabular}


Table XVII: Sampling Pumps used for the experiments (internal coding numbers)

\begin{tabular}{|c|c|}
\hline $02-175-07$ & 5 \\
\hline $02-175-04$ & 4 \\
\hline $02-057-13$ & 9 \\
\hline $02-121-02$ & 2 \\
\hline $02-172-15$ & 10 \\
\hline $02-121-03$ & 3 \\
\hline $02-057-09$ & 7 \\
\hline $02-121-01$ & 1 \\
\hline $02-057-08$ & 6 \\
\hline $02-175-10$ & 8 \\
\hline 511847 & N/A \\
\hline 562388 & N/A \\
\hline 562843 & N/A \\
\hline
\end{tabular}




\section{Appendix 3}

Pictures of human subjects

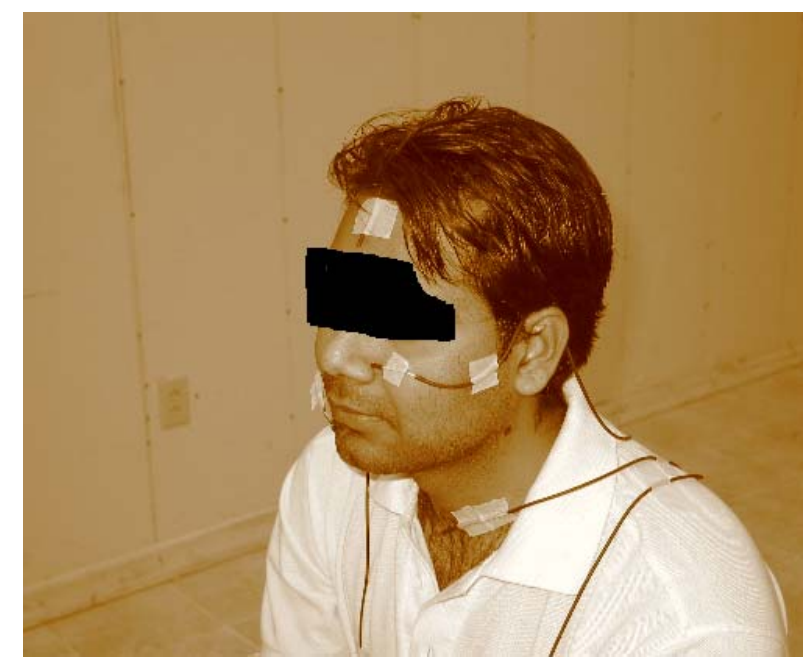

Picture A (Subject 1)

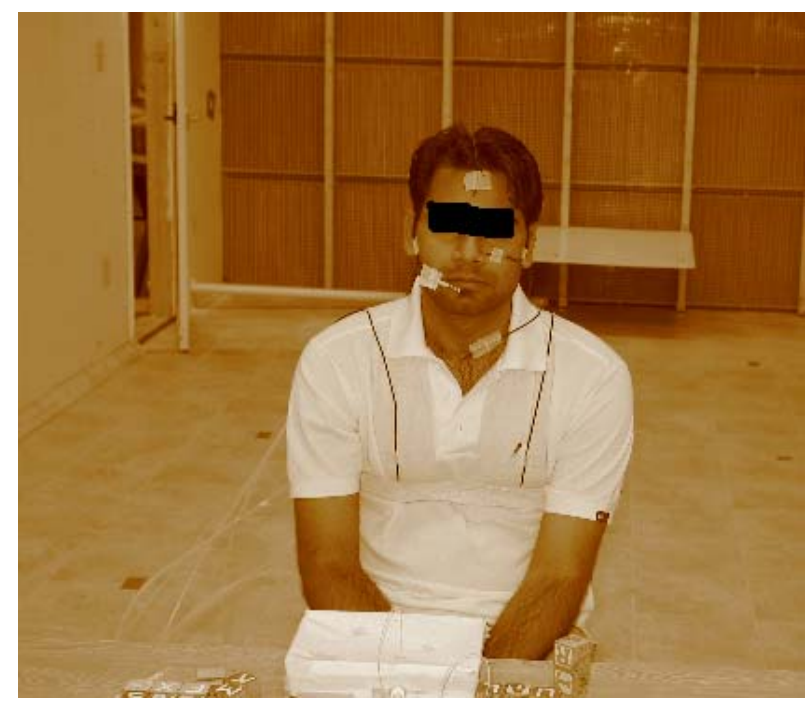

Picture B (Subject 1)

Pictures A and B: Human Subject Connections at Sampling Locations 


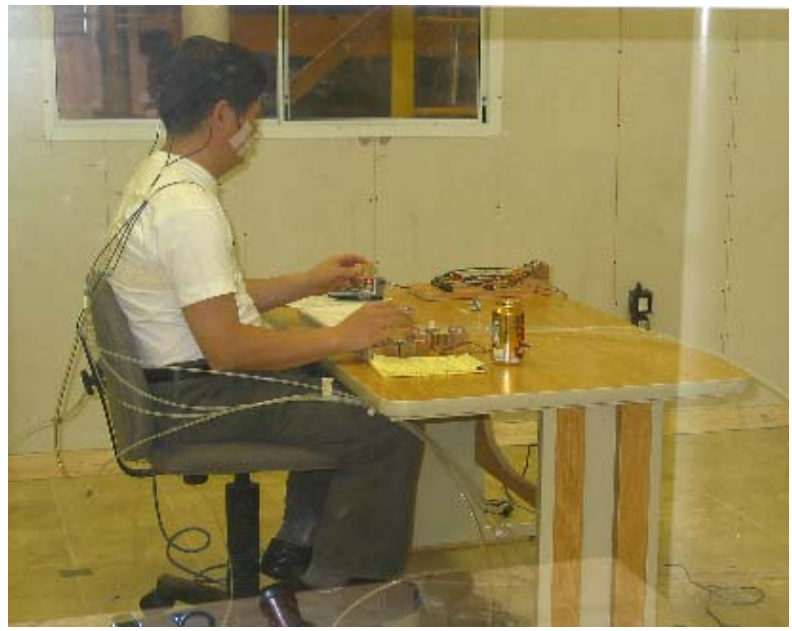

Picture C (Subject 2)

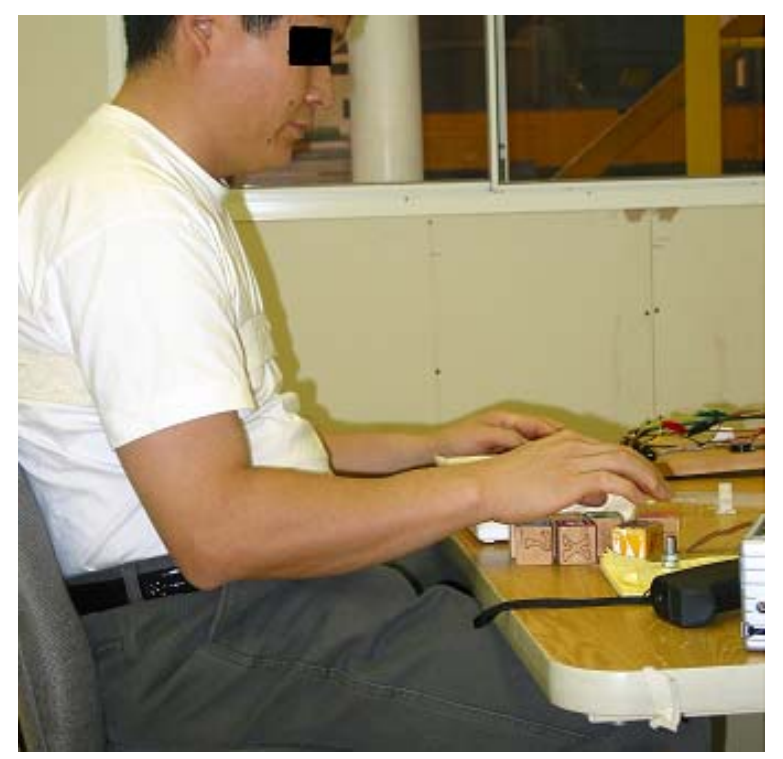

Picture D (Subject 2)

Picture Cand D: Human subject simulating work conditions 


\section{Appendix 4}

\section{GC Assay Parameters}

Table XVIII: GC Assay parameters

\begin{tabular}{|l|c|}
\hline Assay Name & Ethanol_C_65C_12psi_150sec_21Jan03 \\
\hline GC Column & C \\
\hline Curve Fit & Linear \\
\hline Injection & Loop \\
\hline $\begin{array}{l}\text { Injection time } \\
\text { (in seconds) }\end{array}$ & 2 \\
\hline $\begin{array}{l}\text { Analysis time } \\
\text { (in seconds) }\end{array}$ & 140 \\
\hline $\begin{array}{l}\text { Back Flush time (in } \\
\text { seconds) }\end{array}$ & 70 \\
\hline Pump time (in seconds) & 10 \\
\hline Column Temperature & 65 \\
\hline Column Pressure in psig & 12 \\
\hline Slope up mVS & 0.5 \\
\hline Slope down mVS & 1 \\
\hline Min Height. (mV) & 0 \\
\hline Min Area (mVS) & 0 \\
\hline Delay_sec & 75 \\
\hline
\end{tabular}




\section{Appendix 5}

Ethanol known concentration chart

Table XIX: Ethanol 'Known concentration' chart

\begin{tabular}{|c|c|}
\hline $\begin{array}{c}\text { Ethanol Known } \\
\text { ppm }\end{array}$ & $\begin{array}{c}\text { Ethanol Peak Area } \\
(\mathbf{m V S})\end{array}$ \\
\hline 5 & 124 \\
\hline 10 & 245 \\
\hline 10 & 245 \\
\hline 15 & 371 \\
\hline 15 & 373 \\
\hline 20 & 514 \\
\hline 30 & 827 \\
\hline 40 & 1291 \\
\hline 50 & 1515 \\
\hline 50 & 1521 \\
\hline 60 & 2001 \\
\hline 80 & 3174 \\
\hline 122 & 3923 \\
\hline 153 & 5148 \\
\hline 183 & 7101 \\
\hline
\end{tabular}




\section{Appendix 6}

Post analysis GC Calibration sheet

Table XX: Post Analysis GC calibration excel sheet

\begin{tabular}{|l|l|l|l|l|}
\hline Experiments Data Collection Sheet & Investigators Name & Run Type & Seq & Time \\
\hline Ethanol Calibration Using Column C & Santosh & Blank & 0 & 1500 \\
\hline Ethanol Calibration Using Column C & Santosh & Calibration & 153 \\
\hline Ethanol Calibration Using Column C & Santosh & Calibration & 1545 \\
\hline Ethanol Calibration Using Column C & Santosh & Calibration & 1600 \\
\hline Ethanol Calibration Using Column C & Santosh & Calibration & $\mathbf{3}$ & 1600 \\
\hline
\end{tabular}

\begin{tabular}{|l|l|l|l|l|l|}
\hline Date & Amb_T_oC & Atm_Prs_kPa & Et_R.T._Sec & Et_PkAr_mVS & Et_PkHt_mV \\
\hline $27-F e b$ & 24 & 101.325 & - & - & - \\
\hline $27-F e b$ & 24 & 101.325 & 102.7 & 77.7 & 13.3 \\
\hline $27-F e b$ & 24 & 101.325 & 102.8 & 507 & 79.7 \\
\hline $27-F e b$ & 24 & 101.325 & 102.8 & 797 & 124 \\
\hline $27-F e b$ & 24 & 101.325 & 102.9 & 1284 & 200 \\
\hline
\end{tabular}

Nomenclature:

Atm_Prs_kPa- Atmospheric pressure (in kilo Pascal's)

Et_R.T._Sec-Ethanol retention time (in seconds)

Et_PkAr_mVS- Ethanol peak area (in mVS)

Et_PkHt_mV-Ethanol peak height (in $\mathrm{mV}$ ) 


\section{Appendix 7}

Wind tunnel calibration chart

Table XXI: Wind tunnel fpm (feet per minute) calibration chart

\begin{tabular}{|c|c|}
\hline $\begin{array}{l}\text { Wind tunnel } \\
\text { velocity in fpm }\end{array}$ & $\frac{\text { Fan }}{\text { speed }}$ \\
\hline & (rpm) \\
\hline 10 & 156.92 \\
\hline 15 & 235.38 \\
\hline 20 & 313.84 \\
\hline 25 & 392.3 \\
\hline 30 & 470.76 \\
\hline 35 & 549.22 \\
\hline 40 & 627.68 \\
\hline 45 & 706.14 \\
\hline 50 & 784.6 \\
\hline 55 & 863.06 \\
\hline 60 & 941.52 \\
\hline 65 & 1019.98 \\
\hline 70 & 1098.44 \\
\hline 75 & 1176.9 \\
\hline 80 & 1255.36 \\
\hline 85 & 1333.82 \\
\hline 90 & 1412.28 \\
\hline 95 & 1490.74 \\
\hline 100 & 1569.2 \\
\hline 105 & 1647.66 \\
\hline 110 & 1726.12 \\
\hline 115 & 1804.58 \\
\hline 120 & 1883.04 \\
\hline 125 & 1961.5 \\
\hline 130 & 2039.96 \\
\hline 135 & 2118.42 \\
\hline 140 & 2196.88 \\
\hline 145 & 2275.34 \\
\hline 150 & 2353.8 \\
\hline
\end{tabular}




\section{Appendix 8}

Regression analysis results

Table XXII: $\mathbf{C}_{\text {neck }}$ Regression values

\begin{tabular}{|c|c|c|c|c|}
\hline \multicolumn{5}{|c|}{$\begin{array}{l}\text { Dependent variable is: } \quad \mathrm{C}_{\text {neck }} \\
\mathrm{R} \text { squared }=76.1 \% \text { R squared (adjusted) }=73.4 \% \\
\mathrm{~s}=9.424 \text { with } 30-4=26 \text { degrees of freedom }\end{array}$} \\
\hline Source & Sum of Squar & df & Mean Square & F-ratio \\
\hline Regression & 7367.34 & 3 & 2455.78 & 27.6 \\
\hline Residual & 2309.3 & 26 & 88.8191 & \\
\hline Variable & Coefficient & s.e. of Coeff & t-ratio & prob \\
\hline Constant & 98.377 & 43.45 & 2.26 & 0.0321 \\
\hline Wind Tunnel velocity (fpm) & 0.893977 & 0.1017 & 8.79 & 0.0001 \\
\hline Shoulder width (inches) & -1.41479 & 0.6688 & -2.12 & 0.0441 \\
\hline Chest circumference (inches) & -1.77627 & 0.7423 & -2.39 & 0.0242 \\
\hline
\end{tabular}

Table XXIII: $\mathrm{C}_{\text {forehead }}$ Regression values

Dependent variable is: $\quad \mathrm{C}_{\text {forehead }}$

$\mathrm{R}$ squared $=77.4 \% \mathrm{R}$ squared (adjusted) $=75.7 \%$

$\mathrm{s}=5.56$ with $30-3=27$ degrees of freedom

\begin{tabular}{|l|c|c|c|c|}
\hline Source & Sum of Squares & df & Mean Square & F-ratio \\
\hline Regression & 2850.22 & 2 & 1425.11 & 46.1 \\
\hline Residual & 834.537 & 27 & 30.9088 & \\
\hline Variable & Coefficient & S.e. of Coeff & t-ratio & prob \\
\hline Constant & 10.7953 & 5.495 & 1.96 & 0.0598 \\
\hline Wind Tunnel velocity (fpm) & 0.562465 & 0.06 & 9.37 & 0.0001 \\
\hline Chest circumference (inches) & -0.28659 & 0.1405 & -2.04 & 0.0513 \\
\hline
\end{tabular}


Table XXIV: $\mathrm{C}_{\text {right lapel }}$ Regression values

Dependent variable is: $\quad \mathrm{C}_{\text {right lapel }}$

$\mathrm{R}$ squared $=46.0 \% \mathrm{R}$ squared (adjusted) $=44.1 \%$

$\mathrm{s}=12.81$ with $30-2=28$ degrees of freedom

\begin{tabular}{|l|c|c|c|c|}
\hline Source & Sum of Squares & $\underline{\text { df }}$ & Mean Square & $\underline{\text { F-ratio }}$ \\
\hline Regression & 3917.19 & 1 & 3917.19 & 23.9 \\
\hline Residual & 4594.38 & 28 & 164.085 & \\
\hline Variable & Coefficient & s.e. of Coeff & $\underline{\text { t-ratio }}$ & prob \\
\hline Constant & -1.10898 & 5.045 & -0.22 & 0.8276 \\
\hline Wind Tunnel velocity (fpm) & 0.675422 & 0.1382 & 4.89 & 0.0001 \\
\hline
\end{tabular}

Table XXV: $\mathrm{C}_{\text {left lapel }}$ Regression values

Dependent variable is: $\quad \mathrm{C}_{\text {left lapel }}$

$\mathrm{R}$ squared $=58.4 \% \mathrm{R}$ squared (adjusted) $=56.9 \%$

$\mathrm{s}=8.472$ with $30-2=28$ degrees of freedom

\begin{tabular}{|l|c|c|c|c|}
\hline Source & Sum of Squares & $\underline{\mathrm{df}}$ & $\underline{\text { Mean Square }}$ & $\underline{\underline{\text { F-ratio }}}$ \\
\hline Regression & 2823.83 & 1 & 2823.83 & 39.3 \\
\hline Residual & 2009.75 & 28 & 71.7767 & \\
\hline Variable & Coefficient & $\underline{\text { s.e. of Coeff }}$ & $\underline{\text { t-ratio }}$ & prob \\
\hline Constant & -2.83637 & 3.336 & -0.85 & 0.4025 \\
\hline Wind Tunnel velocity $(\mathrm{fpm})$ & 0.573465 & 0.09143 & 6.27 & 0.0001 \\
\hline
\end{tabular}


Table XXVI: $\mathrm{C}_{\text {chest }}$ Regression values

\begin{tabular}{|c|c|c|c|c|}
\hline \multicolumn{5}{|c|}{$\begin{array}{l}\text { Dependent variable is: } \quad C_{\text {Chest }} \\
\text { R squared }=69.1 \% \text { R squared (adjusted) }=65.6 \% \\
s=15.19 \text { with } 30-4=26 \text { degrees of freedom }\end{array}$} \\
\hline Source & \begin{tabular}{|l} 
Sum of \\
Squares
\end{tabular} & df & $\begin{array}{l}\text { Mean } \\
\text { Square }\end{array}$ & F-ratio \\
\hline Regression & 13431.5 & 3 & 4477.17 & 19.4 \\
\hline Residual & 5998.91 & 26 & 230.727 & \\
\hline Variable & Coefficient & $\begin{array}{l}\text { S.e. of } \\
\text { Coeff }\end{array}$ & t-ratio & prob \\
\hline Constant & 269.749 & 70.02 & 3.85 & 0.0007 \\
\hline Wind Tunnel velocity (fpm) & 1.05572 & 0.1639 & 6.44 & 0.0001 \\
\hline Shoulder width (inches) & -4.40975 & 1.078 & -4.09 & 0.0004 \\
\hline Chest circumference (inches) & -4.35158 & 1.196 & -3.64 & 0.0012 \\
\hline
\end{tabular}

Table XXVII: $\mathbf{C}_{\text {nose }}$ Regression values

\begin{tabular}{|c|c|c|c|c|}
\hline $\begin{array}{l}\text { Dependent variable is: } \\
\mathrm{R} \text { squared }=63.0 \% \mathrm{R} \text { squared (adjusted) }=60.3 \% \\
\mathrm{~S}=8.163 \text { with } 30-3=27 \text { degrees of freedom }\end{array}$ & $\mathrm{C}_{\text {nose }}$ & & & \\
\hline Source & $\frac{\text { Sum of }}{\text { Squares }}$ & df & $\begin{array}{l}\text { Mean } \\
\text { Square }\end{array}$ & F-ratio \\
\hline Regression & 3062.2 & 2 & 1531.1 & 23 \\
\hline Residual & 1799 & 27 & 66.6297 & \\
\hline Variable & Coefficient & $\begin{array}{l}\text { s.e. of } \\
\text { Coeff }\end{array}$ & t-ratio & prob \\
\hline Constant & 6.16635 & 3.651 & 1.69 & 0.1027 \\
\hline Wind Tunnel velocity (fpm) & 0.56946 & 0.0880 & 6.46 & 0.0001 \\
\hline Nose sampling Rate & -7.4939 & 3.579 & -2.09 & 0.0458 \\
\hline
\end{tabular}


Table XXVIII: $\log \left(\mathrm{C}_{\text {nose }}\right)$ Regression values

\begin{tabular}{|c|c|c|c|c|}
\hline \multicolumn{5}{|c|}{$\begin{array}{l}\text { Dependent variable is: } \log \left(\mathrm{C}_{\text {nose }}\right) \\
\mathrm{R} \text { squared }=65.3 \% \mathrm{R} \text { squared (adjusted) }=62.7 \% \\
\mathrm{~S}=0.188 \text { with } 30-3=27 \text { degrees of freedom }\end{array}$} \\
\hline Source & $\begin{array}{l}\text { Sum of } \\
\text { Squares } \\
\end{array}$ & $\underline{\mathrm{df}}$ & Mean Square & F-ratio \\
\hline Regression & 1.79198 & 2 & 0.895989 & 25.4 \\
\hline Residual & 0.95411 & 27 & 0.035338 & \\
\hline Variable & Coefficient & $\begin{array}{l}\text { s.e. of } \\
\text { Coeff }\end{array}$ & t-ratio & prob \\
\hline Constant & 1.15095 & 0.5682 & 2.03 & 0.0528 \\
\hline Log (chest circumference) & -0.80524 & 0.3456 & -2.33 & 0.0275 \\
\hline Log (wind tunnel velocity-fpm) & 0.91527 & 0.1358 & 6.74 & 0.0001 \\
\hline
\end{tabular}

Table XXIX: $\log \left(\mathrm{C}_{\text {neck }}\right)$ Regression values

Dependent variable is:

$\log ($ Cneck)

$\mathrm{R}$ squared $=74.5 \% \mathrm{R}$ squared $($ adjusted $)=72.6 \%$

$\mathrm{s}=0.1927$ with $30-3=27$ degrees of freedom

\begin{tabular}{|l|c|c|c|c|}
\hline Source & Sum of Squares & df & Mean Square & F-ratio \\
\hline Regression & 2.92843 & 2 & 1.46421 & 39.4 \\
\hline Residual & 1.00241 & 27 & 0.037126 & \\
\hline Variable & Coefficient & $\underline{\underline{\text { S.e. of }}}$ & & poeff \\
\hline Constant & 3.59625 & 1.512 & 2.38 & 0.0247 \\
\hline Log (wind tunnel velocity-fpm) & 1.17968 & 0.1392 & 8.48 & 0.0001 \\
\hline Log (Chest width) & -3.13025 & 1.175 & -2.66 & 0.0129 \\
\hline
\end{tabular}


Table XXX: Log $\left(C_{\text {right lapel }}\right)$ Regression values

\begin{tabular}{|c|c|c|c|c|}
\hline \multicolumn{5}{|c|}{$\begin{array}{l}\text { Dependent variable is: } \log \left(\mathrm{C}_{\text {right lapel }}\right) \\
\mathrm{R} \text { squared }=61.5 \% \mathrm{R} \text { squared (adjusted })=60.1 \% \\
\mathrm{~S}=0.2355 \text { with } 30-2=28 \text { degrees of freedom }\end{array}$} \\
\hline Source & $\begin{array}{l}\text { Sum of } \\
\text { Squares } \\
\end{array}$ & df & Mean Square & F-ratio \\
\hline Regression & 2.47951 & 1 & 2.47951 & 44.7 \\
\hline Residual & 1.55278 & 28 & 0.055456 & \\
\hline Variable & Coefficient & s.e. of Coef & t-ratio & prob \\
\hline Constant & -0.4675 & 0.2487 & -1.88 & 0.0706 \\
\hline Log (wind tunnel velocity-fpm) & 1.13737 & 0.1701 & 6.69 & 0.0001 \\
\hline
\end{tabular}

Table XXXI: $\log \left(C_{\text {left lapel }}\right)$ Regression values

\begin{tabular}{|c|c|c|c|c|}
\hline \multicolumn{5}{|c|}{$\begin{array}{l}\text { Dependent variable is: } \quad \log \left(\mathrm{C}_{\text {left lapel }}\right) \\
\mathrm{R} \text { squared }=66.0 \% \mathrm{R} \text { squared (adjusted })=64.8 \% \\
\mathrm{~S}=0.2374 \text { with } 30-2=28 \text { degrees of freedom }\end{array}$} \\
\hline Source & $\begin{array}{l}\text { Sum of } \\
\text { Squares }\end{array}$ & $\underline{\mathrm{df}}$ & $\begin{array}{l}\text { Mean } \\
\text { Square }\end{array}$ & F-ratio \\
\hline Regression & 3.06648 & 1 & 3.06648 & 54.4 \\
\hline Residual & 1.57781 & 28 & 0.05635 & \\
\hline Variable & Coefficient & $\frac{\text { S.e. of }}{\text { Coeff }}$ & t-ratio & prob \\
\hline Constant & -0.78713 & 0.2507 & -3.14 & 0.004 \\
\hline Log (wind tunnel velocity-fpm) & 1.26485 & 0.1715 & 7.38 & .0001 \\
\hline
\end{tabular}


Table XXXII: $\log \left(\mathrm{C}_{\text {left lapel }}\right)$ Regression values

Dependent variable is: $\quad \log \left(\mathrm{C}_{\text {left lapel }}\right)$

$\mathrm{R}$ squared $=73.5 \% \mathrm{R}$ squared (adjusted) $=70.5 \%$

$\mathrm{s}=0.2066$ with $30-4=26$ degrees of freedom

\begin{tabular}{|l|c|c|c|c|}
\hline Source & Sum of Squares & df & Mean Square & F-ratio \\
\hline Regression & 3.07936 & 3 & 1.02645 & 24 \\
\hline Residual & 1.10971 & 26 & 0.042681 & \\
\hline Variable & Coefficient & s.e. of Coeff & t-ratio & prob \\
\hline Constant & 13.1736 & 3.243 & 4.06 & 0.0004 \\
\hline Log (Chest circumference) & 4.26974 & 1.147 & 3.72 & 0.001 \\
\hline Log (Velocity) & 1.10074 & 0.1492 & 7.38 & 0.0001 \\
\hline Log (Chest Width) & -15.6582 & 3.805 & -4.11 & 0.0003 \\
\hline
\end{tabular}

Table XXXIII: $\log \left(\mathrm{Cf}_{\text {orehead }}\right)$ Regression values

Dependent variable is: $\quad \log \left(\mathrm{C}_{\text {forehead }}\right)$

$\mathrm{R}$ squared $=74.3 \% \mathrm{R}$ squared (adjusted) $=72.4 \%$

$\mathrm{s}=0.1689$ with $30-3=27$ degrees of freedom

\begin{tabular}{|l|c|c|c|c|}
\hline Source & $\begin{array}{l}\text { Sum } \\
\text { Squares }\end{array}$ & df & \multicolumn{1}{l|}{$\begin{array}{l}\text { Mean } \\
\text { Square }\end{array}$} & F-ratio \\
\hline Regression & 2.22079 & 2 & 1.1104 & 38.9 \\
\hline Residual & 0.769838 & 27 & 0.02851 & \\
\hline Variable & Coefficient & s.e. of & & \\
\hline Constant & 0.986586 & 0.5104 & $\underline{\text { t-ratio }}$ & \multicolumn{1}{l|}{ prob } \\
\hline Log (Chest circumference) & -0.83592 & 0.3104 & -2.69 & 0.0638 \\
\hline Log (Velocity-fpm) & 1.02672 & 0.122 & 8.42 & 0.012 \\
\hline
\end{tabular}


Table XXXIV: $\log \left(\mathrm{C}_{\text {neck }} / \mathrm{C}_{\text {nose }}\right)$ Regression values

Dependent variable is: $\quad \log \left(\mathrm{C}_{\text {neck }} / \mathrm{C}_{\text {nose }}\right)$

$\mathrm{R}$ squared $=35.4 \% \mathrm{R}$ squared (adjusted) $=28.0 \%$

$\mathrm{s}=0.1357$ with $30-4=26$ degrees of freedom

\begin{tabular}{|l|l|c|c|c|}
\hline Source & Sum of & & & \\
\cline { 2 - 5 } Squares & df & Mean Square & F-ratio \\
\hline Regression & 0.262424 & 3 & 0.087475 & 4.75 \\
\hline Residual & 0.478546 & 26 & 0.018406 & \\
\hline Variable & Coefficient & S.e. of Coeff & t-ratio & prob \\
\hline Constant & 5.1345 & 2.13 & 2.41 & 0.0233 \\
\hline Log (Chest circumference-inches) & 1.9007 & 0.7532 & 2.52 & 0.0181 \\
\hline Log (wind tunnel velocity-fpm) & 0.2628 & 0.098 & 2.68 & 0.0125 \\
\hline Log (Chest width-inches) & -6.5646 & 2.499 & -2.63 & 0.0143 \\
\hline
\end{tabular}

Table XXXV: $\log \left(\mathrm{C}_{\text {chest }} / \mathrm{C}_{\text {nose }}\right)$ Regression values

\begin{tabular}{|c|c|c|c|c|}
\hline \multicolumn{5}{|c|}{$\begin{array}{l}\text { Dependent variable is: } \quad \log \left(\mathrm{C}_{\text {chest }} / \mathrm{C}_{\text {nose }}\right) \\
\mathrm{R} \text { squared }=73.9 \% \mathrm{R} \text { squared (adjusted })=69.7 \% \\
\mathrm{~s}=0.1206 \text { with } 30-5=25 \text { degrees of freedom }\end{array}$} \\
\hline Source & $\begin{array}{l}\text { Sum of } \\
\text { Squares } \\
\end{array}$ & $\underline{\mathrm{df}}$ & $\begin{array}{l}\text { Mean } \\
\text { Square } \\
\end{array}$ & F-ratio \\
\hline Regression & 1.03017 & 4 & 0.25754 & 17.7 \\
\hline Residual & 0.363723 & 25 & 0.01454 & \\
\hline Variable & Coefficient & s.e. of Coeff & t-ratio & prob \\
\hline Constant & 13.0953 & 1.928 & 6.79 & ${ }^{2} 0.0001$ \\
\hline Log (Chest circumference) & 5.51053 & 0.686 & 8.03 & ${ }^{2} 0.0001$ \\
\hline Log (wind tunnel velocity-fpm) & 0.186998 & 0.08713 & 2.15 & 0.0418 \\
\hline Log (Nose sampling rate) & 0.15901 & 0.05591 & 2.84 & 0.0088 \\
\hline Log (Chest width) & -16.9672 & 2.266 & -7.49 & ${ }^{2} 0.0001$ \\
\hline
\end{tabular}


Table XXXVI: $\log \left(\mathbf{C}_{\text {right lapel }} / \mathbf{C}_{\text {nose }}\right)$ Regression values

\begin{tabular}{|c|c|c|c|c|}
\hline \multicolumn{5}{|c|}{$\begin{array}{l}\text { Dependent variable is: } \quad \log \left(C_{\text {right lapel }} / C_{\text {nose }}\right) \\
\mathrm{R} \text { squared }=19.2 \% \mathrm{R} \text { squared (adjusted })=13.2 \% \\
\mathrm{~S}=0.1828 \text { with } 30-3=27 \text { degrees of freedom }\end{array}$} \\
\hline Source & \begin{tabular}{|l|} 
Sum of \\
Squares \\
\end{tabular} & If & Mean Square & F-ratio \\
\hline Regression & 0.21386 & 2 & 0.106932 & 3.2 \\
\hline Residual & 0.90183 & 27 & 0.033401 & \\
\hline Variable & $\frac{\frac{\text { Coeffici }}{\text { ent }}}{\text { ent }}$ & s.e. of Coeff & $\underline{\text { t-ratio }}$ & prob \\
\hline Constant & -1.35071 & 0.5525 & -2.44 & 0.02 \\
\hline Log (Chest circumference) & 0.63144 & 0.336 & 1.88 & 0.07 \\
\hline Log (wind tunnel velocity-fpm) & 0.22243 & 0.132 & 1.69 & 0.10 \\
\hline
\end{tabular}

Table XXXVII: $\log \left(C_{\text {left tapel }} / C_{\text {nose }}\right)$ Regression values

\begin{tabular}{|c|c|c|c|c|}
\hline \multicolumn{5}{|c|}{$\begin{array}{l}\text { Dependent variable is: } \log \left(\mathrm{C}_{\text {left lapel }} / \mathrm{C}_{\text {nose }}\right) \\
\mathrm{R} \text { squared }=44.1 \% \mathrm{R} \text { squared (adjusted })=35.1 \% \\
\mathrm{~s}=0.1682 \text { with } 30-5=25 \text { degrees of freedom }\end{array}$} \\
\hline Source & Sum of Squares & df & \begin{tabular}{|l} 
Mean \\
Square
\end{tabular} & $\begin{array}{l}\text { F- } \\
\text { ratio }\end{array}$ \\
\hline Regression & 0.557214 & 4 & 0.139303 & 4.92 \\
\hline Residual & 0.707605 & 25 & 0.028304 & \\
\hline Variable & Coefficient & $\begin{array}{l}\text { s.e. of } \\
\text { Coeff }\end{array}$ & t-ratio & prob \\
\hline Constant & 4.17186 & 2.689 & 1.55 & 0.133 \\
\hline Log (Chest circumference) & 2.57986 & 0.9568 & 2.7 & 0.012 \\
\hline Log (wind tunnel velocity-fpm) & 0.349609 & 0.1215 & 2.88 & 0.008 \\
\hline Log (Nose sampling rate) & 0.173789 & 0.07798 & 2.23 & 0.035 \\
\hline Log (Chest width) & -6.87475 & 3.16 & -2.18 & 0.039 \\
\hline
\end{tabular}


Table XXXVIII: $\log \left(\mathbf{C}_{\text {forehead }} / \mathbf{C}_{\text {nose }}\right)$ Regression values

\begin{tabular}{|c|c|c|c|c|}
\hline $\begin{array}{l}\text { Dependent variable is: } \\
\mathrm{R} \text { squared }=10.5 \% \mathrm{R} \text { squared (adjusted } \\
\mathrm{s}=0.1041 \text { with } 30-2=28 \text { degrees of } \mathrm{f}\end{array}$ & \multicolumn{4}{|c|}{$\log \left(\mathrm{C}_{\text {forehead }} / \mathrm{C}_{\text {nose }}\right)$} \\
\hline ( & $\begin{array}{l}\text { Sum of } \\
\text { Squares }\end{array}$ & df & Mean Square & $\begin{array}{l}\text { F- } \\
\text { ratio } \\
\end{array}$ \\
\hline Regression & 0.0356 & 1 & 0.035695 & 3.29 \\
\hline Residual & 0.3035 & 28 & 0.010839 & \\
\hline Variable & \multicolumn{3}{|c|}{ Coefficient s.e. of Coefftt-ratio } & prob \\
\hline Constant & -0.0089 & 0.03005 & -0.298 & 0.76 \\
\hline Log (Nose sampling rate) & 0.0854 & 0.04709 & 1.81 & 0.08 \\
\hline
\end{tabular}

Table XXXIX: $\left(\mathbf{C}_{\text {neck }} / \mathbf{C}_{\text {nose }}\right)$ Regression values

Dependent variable is: $\quad \mathrm{C}_{\text {neck }} / \mathrm{C}_{\text {nose }}$

$\mathrm{R}$ squared $=25.6 \% \mathrm{R}$ squared (adjusted) $=17.1 \%$

$\mathrm{s}=0.588$ with $30-4=26$ degrees of freedom

\begin{tabular}{|c|c|c|c|c|}
\hline Source & 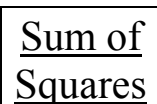 & df & $\underline{\text { Mean }}$ & $\begin{array}{l}\mathrm{F}- \\
\text { ratio } \\
\end{array}$ \\
\hline Regression & 3.0989 & 3 & 1.03299 & 2.99 \\
\hline Residual & 8.9880 & 26 & 0.34569 & \\
\hline Variable & $\frac{\text { Coeffici }}{\text { ent }}$ & $\begin{array}{l}\frac{\text { s.e. of }}{\text { Coeff }} \\
\end{array}$ & t-ratio & prob \\
\hline Constant & $6 . \overline{5392}$ & 2.71 & $\overline{2.41}$ & 0.023 \\
\hline Wind tunnel velocity-fpm & 0.0130 & 0.006345 & 2.05 & 0.050 \\
\hline Shoulder width & -0.091 & 0.04173 & -2.19 & 0.038 \\
\hline Chest circumference & -0.092 & 0.04631 & -2 & 0.056 \\
\hline
\end{tabular}


Table XXXX: $\left(\mathrm{C}_{\text {forehead }} / \mathrm{C}_{\text {nose }}\right)$ Regression values

\begin{tabular}{|c|c|c|c|c|}
\hline Dependent variable is: & \multicolumn{4}{|c|}{$\mathrm{C}_{\text {forehead }} / \mathrm{C}_{\text {nose }}$} \\
\hline Source & $\begin{array}{l}\text { Sum of } \\
\text { Squares } \\
\end{array}$ & & $\begin{array}{l}\text { Mean } \\
\text { Square } \\
\end{array}$ & \begin{tabular}{|l} 
F- \\
ratio \\
\end{tabular} \\
\hline Regression & 0.20011 & 1 & 0.200119 & 2.26 \\
\hline Residual & 2.48272 & 28 & 0.088669 & \\
\hline Variable & Coeffici & $\begin{array}{ll}\text { s.e. } & 0 \\
\text { Coeff }\end{array}$ & t-ratio & nrob \\
\hline Constant & 0.76476 & 0.1173 & 6.52 & 0.000 \\
\hline Wind tunnel velocity-fpm & 0.00482 & 0003213 & 1.5 & 0.144 \\
\hline
\end{tabular}

Table XXXXI: $\left(\mathrm{C}_{\text {right lapel }} / \mathbf{C}_{\text {nose }}\right)$ Regression values

\begin{tabular}{|c|c|c|c|c|}
\hline $\begin{array}{l}\text { Dependent variable is: } \\
\mathrm{R} \text { squared }=24.2 \% \mathrm{R} \text { squared (adjusted) }=18.6 \% \\
\mathrm{~S}=0.4276 \text { with } 30-3=27 \text { degrees of freedom }\end{array}$ & $\mathrm{C}_{\text {right lapel }} / \mathrm{C}_{\mathrm{no}}$ & & & \\
\hline y & \begin{tabular}{|ll} 
Sum & of \\
Squares &
\end{tabular} & f $\left.\right|_{\text {df }}$ & \begin{tabular}{|l|} 
Mean \\
Square
\end{tabular} & F-ratio \\
\hline Regression & 1.57 & 2 & 0.7879 & 4.31 \\
\hline Residual & 4.93 & 27 & 0.1828 & \\
\hline Variable & Coefficient & $\begin{array}{l}\text { s.e. of } \\
\text { Coeff }\end{array}$ & t-ratio & prob \\
\hline Constant & 1.1480 & 0.3022 & 3.8 & 0.0008 \\
\hline Wind tunnel velocity-fpm & 0.0100 & 0.00461 & 2.17 & 0.0387 \\
\hline Shoulder width & -0.019 & 0.00974 & -1.99 & 0.057 \\
\hline
\end{tabular}


Table XXXXII: $\left(\mathbf{C}_{\text {left lapel }} / \mathbf{C}_{\text {nose }}\right)$ Regression values

\begin{tabular}{|c|c|c|c|c|}
\hline \multicolumn{5}{|c|}{$\begin{array}{l}\text { Dependent variable is: } \quad \mathrm{C}_{\text {leftlapel }} / \mathrm{C}_{\text {nose }} \\
\mathrm{R} \text { squared }=50.7 \% \mathrm{R} \text { squared (adjusted) }=42.8 \% \\
\mathrm{~s}=0.237 \text { with } 30-5=25 \text { degrees of freedom }\end{array}$} \\
\hline 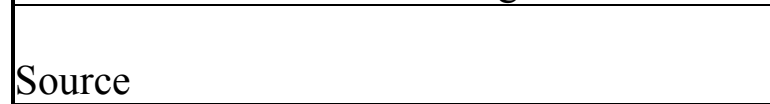 & \begin{tabular}{|l|} 
Sum of \\
Squares
\end{tabular} & df & $\begin{array}{l}\text { Mean } \\
\text { Square }\end{array}$ & $\begin{array}{l}\text { F- } \\
\text { ratio } \\
\end{array}$ \\
\hline Regression & 1.44506 & 4 & 0.361264 & 6.43 \\
\hline Residual & 1.40471 & 25 & 0.056188 & \\
\hline Variable & \begin{tabular}{|l|} 
Coefficie \\
$\mathrm{nt}$
\end{tabular} & $\begin{array}{l}\text { S.e. of } \\
\text { Coeff }\end{array}$ & t-ratio & prob \\
\hline Constant & 2.9475 & 1.245 & 2.37 & 0.025 \\
\hline Wind tunnel velocity-fpm & 0.009851 & 0.002558 & 3.85 & 0.000 \\
\hline Chest Width & -0.10593 & 0.05593 & -1.89 & 0.069 \\
\hline Shoulder width & -0.02581 & 0.009059 & -2.85 & 0.008 \\
\hline Nose sampling rate & 0.230863 & 0.1065 & 2.17 & 0.039 \\
\hline
\end{tabular}

Table XXXXIII:( $\left.\mathbf{C}_{\text {chest }} / \mathbf{C}_{\text {nose }}\right)$ Regression values

\begin{tabular}{|c|c|c|c|c|}
\hline \multicolumn{5}{|c|}{$\begin{array}{l}\text { Dependent variable is: } \quad \mathrm{C}_{\text {chest }} / \mathrm{C}_{\text {nose }} \\
\mathrm{R} \text { squared }=51.6 \% \mathrm{R} \text { squared (adjusted) }=43.9 \% \\
\mathrm{~s}=0.852 \text { with } 30-5=25 \text { degrees of freedom }\end{array}$} \\
\hline Source & Sum of Squa & df & \begin{tabular}{|l} 
Mean \\
Square
\end{tabular} & F-ratio \\
\hline Regression & 19.3755 & 4 & 4.84388 & 6.67 \\
\hline Residual & 18.1462 & 25 & 0.725849 & \\
\hline Variable & Coefficient & s.e. of Coef & t-ratio & prob \\
\hline Constant & 16.924 & 3.962 & 4.27 & 0.0002 \\
\hline Wind tunnel velocity-fpm & 0.013772 & 0.009195 & 1.5 & 0.1467 \\
\hline Shoulder width & -0.27495 & 0.0617 & -4.46 & 0.0002 \\
\hline Chest circumference & -0.25244 & 0.06799 & -3.71 & 0.001 \\
\hline Nose sampling rate & 0.935386 & 0.3828 & 2.44 & 0.0219 \\
\hline
\end{tabular}




\section{Appendix 9}

Plots of dependent variables vs. independent variables

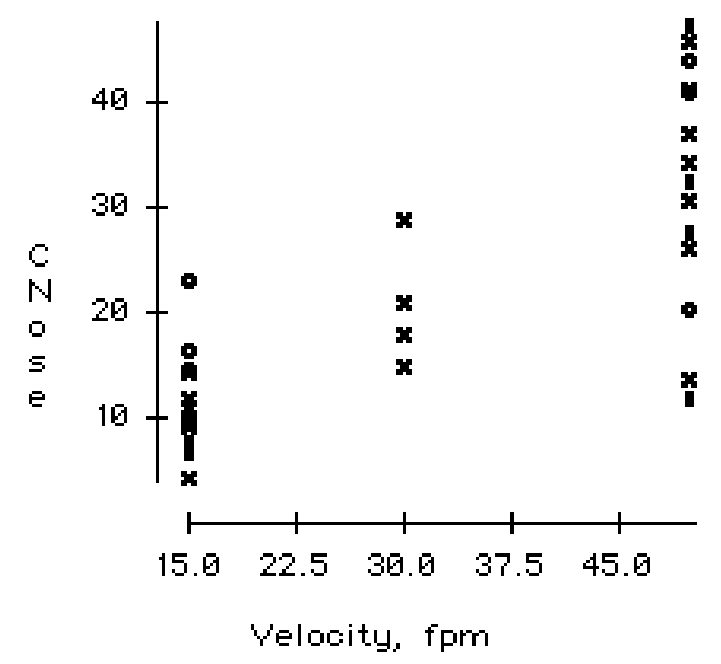

Figure Appendix 16.1: All $C_{\text {nose }}$ data with wind tunnel Velocity

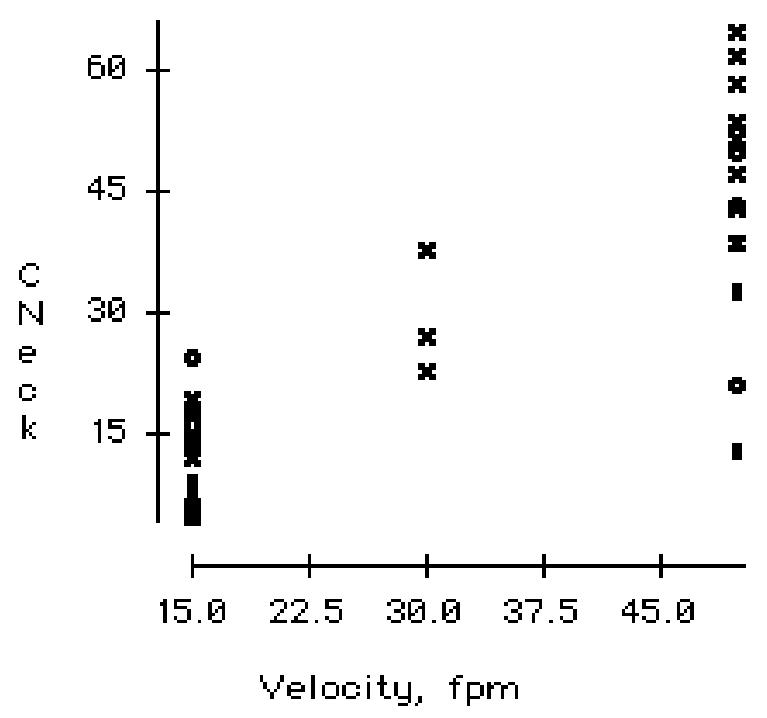

Figure Appendix 16.2: All $C_{\text {neck }}$ data with wind tunnel Velocity 


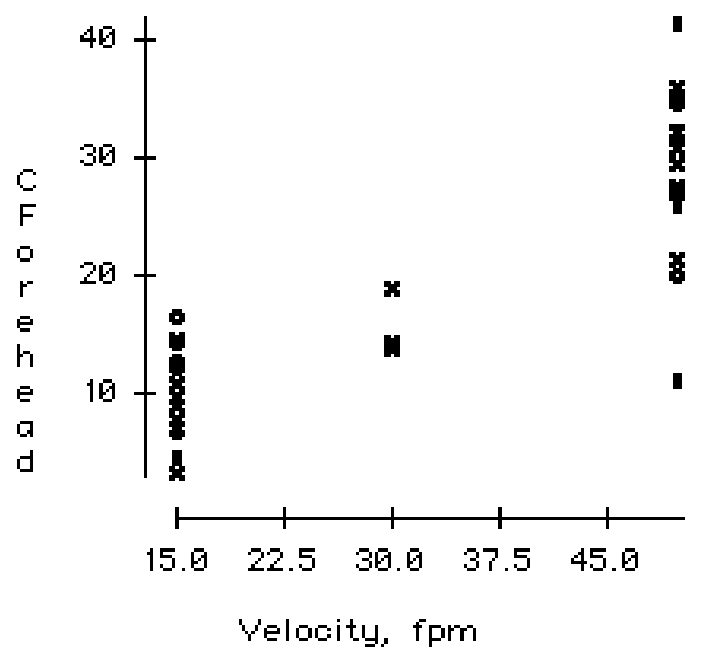

Figure Appendix 16.3: All $\mathrm{C}_{\text {forehead }}$ data with wind tunnel Velocity

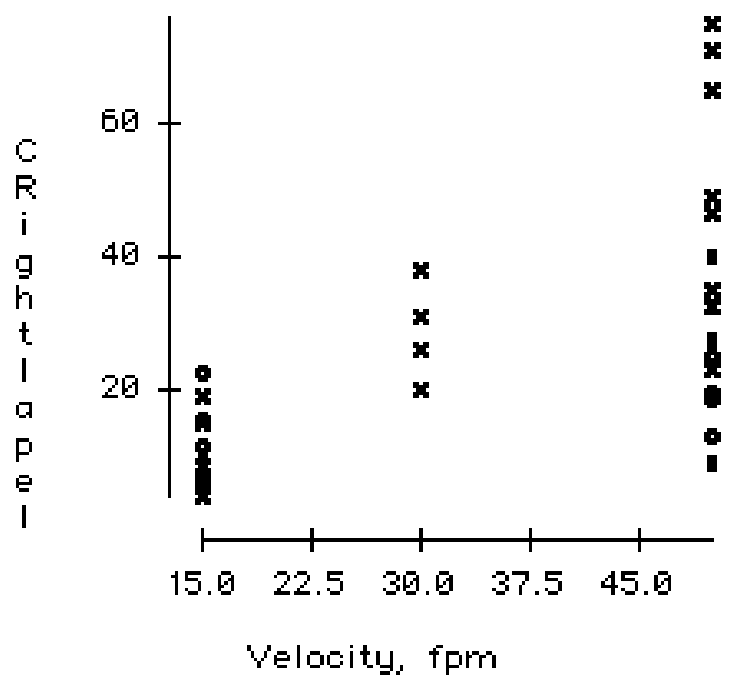

Figure Appendix 16.4: All $C_{\text {right lapel }}$ data with wind tunnel Velocity 


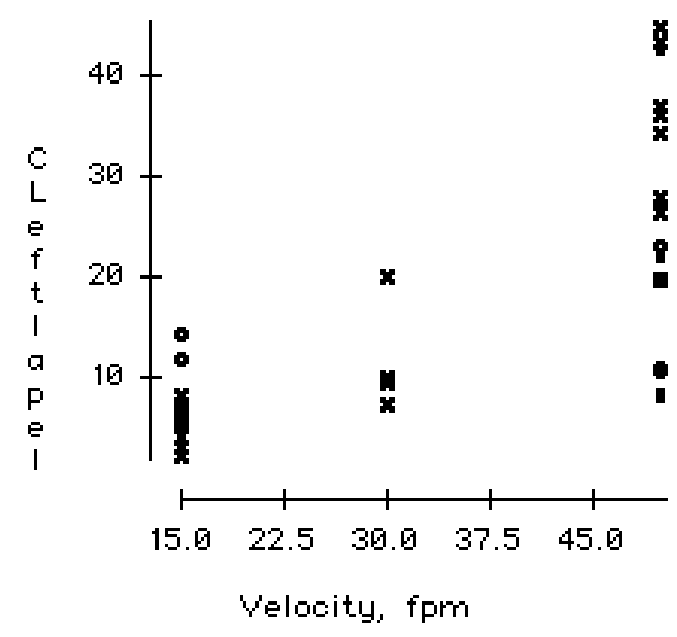

Figure Appendix 16.5: All $\mathrm{C}_{\text {left lapel }}$ data with wind tunnel Velocity

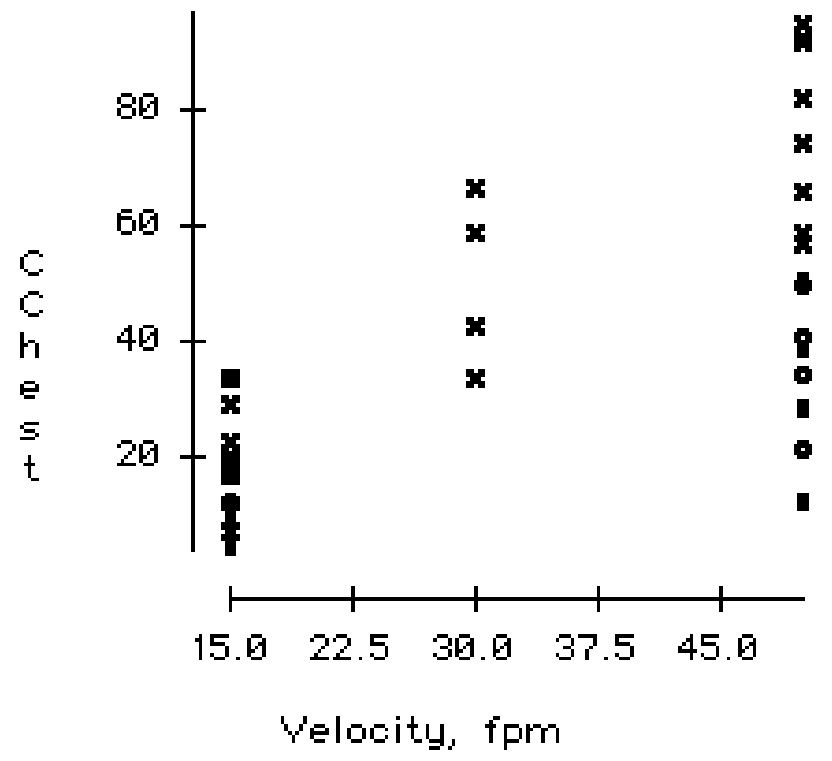

Figure Appendix 16.6: All $C_{\text {chest }}$ data with wind tunnel Velocity 


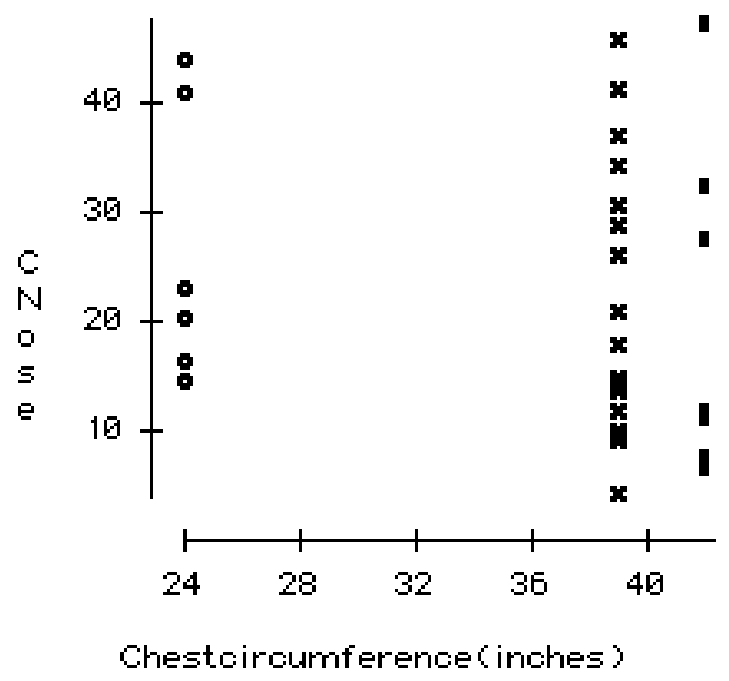

Figure Appendix 17.1: All $C_{\text {nose }}$ data with Chest circumference

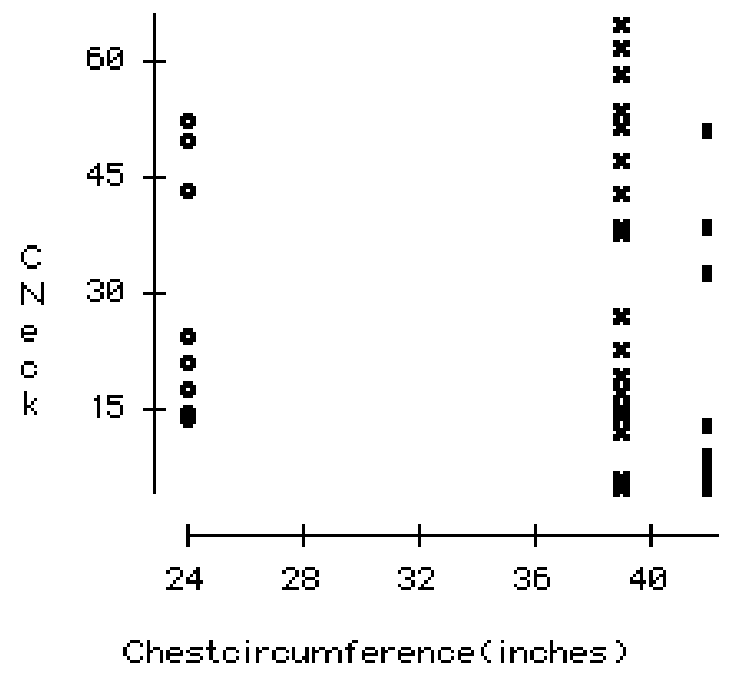

Figure Appendix 17.2: All $C_{\text {neck }}$ data with Chest circumference 


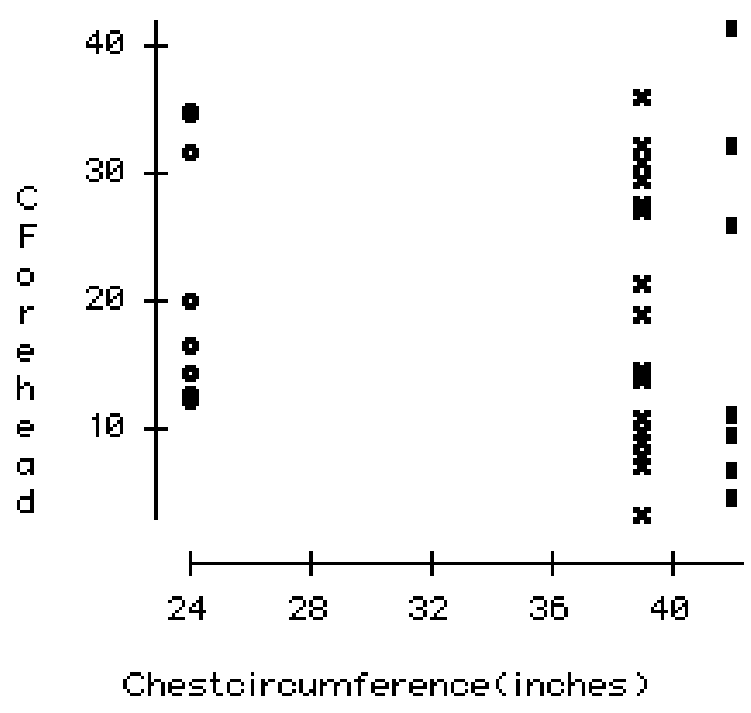

Figure Appendix 17.3: All $C_{\text {forehead }}$ data with Chest circumference

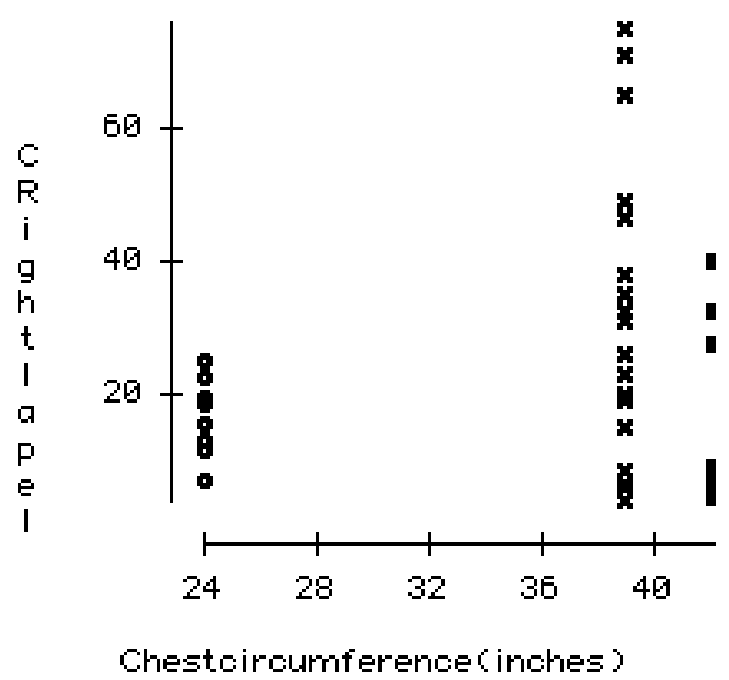

Figure Appendix 17.4: All $C_{\text {right lapel }}$ data with Chest circumference 


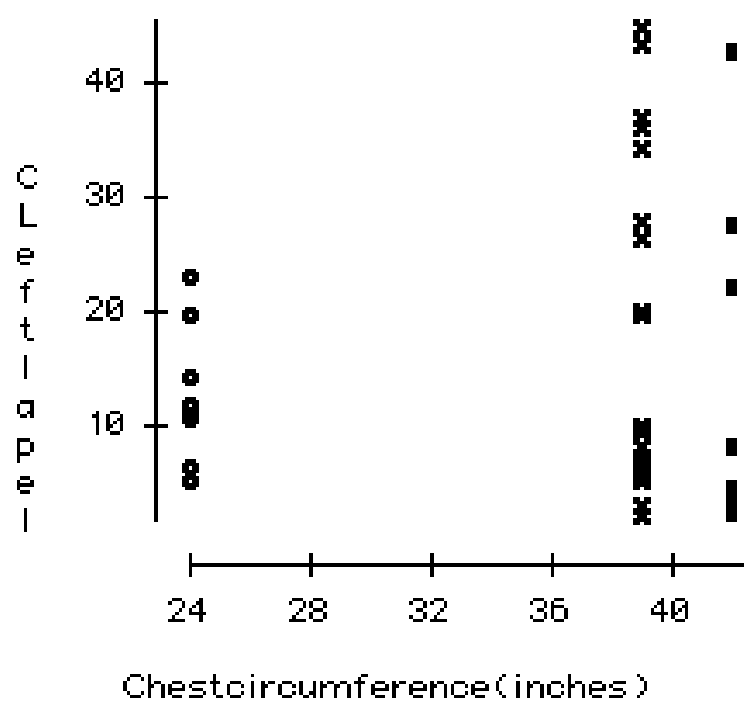

Figure Appendix 17.5: All $C_{\text {left lapel }}$ data with Chest circumference

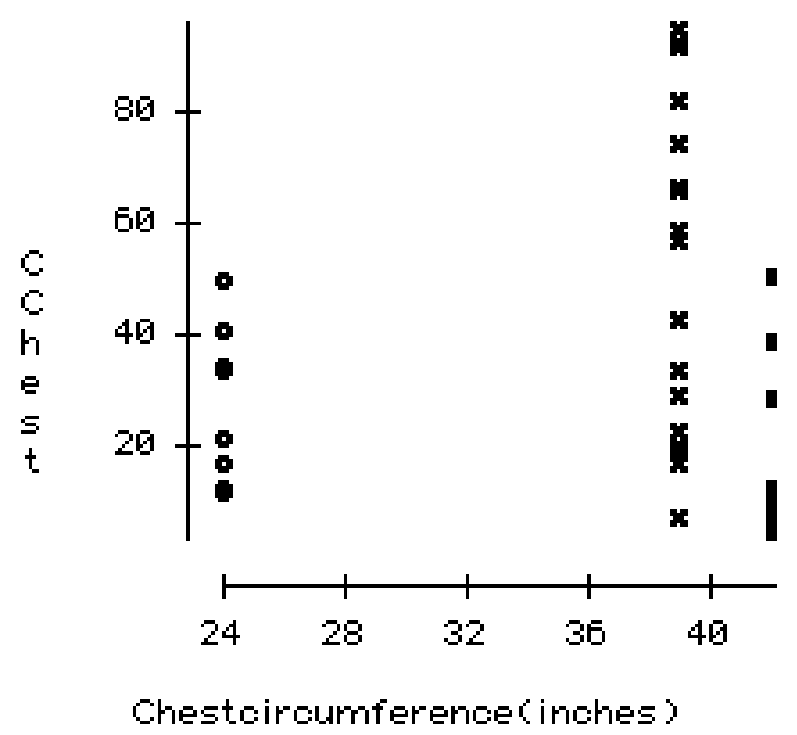

Figure Appendix 17.6: All $C_{\text {chest }}$ data with Chest circumference 


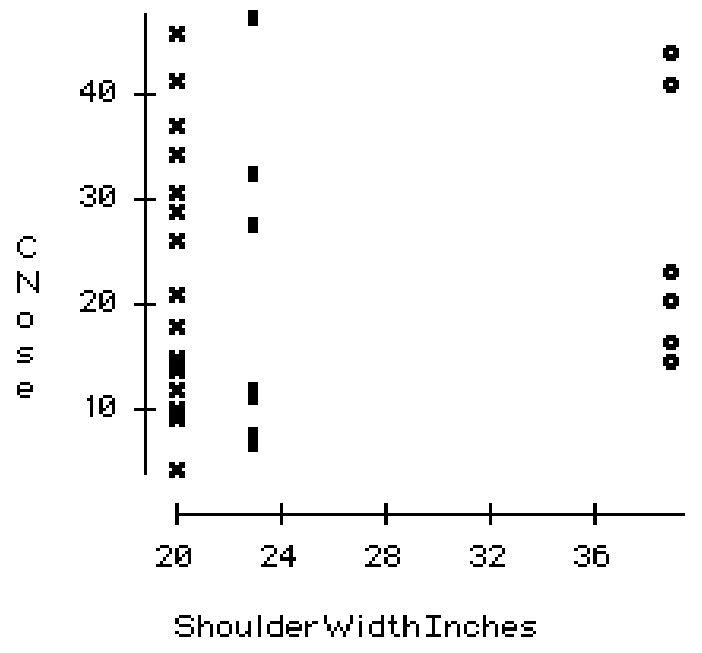

Figure Appendix 18.1: All $\mathrm{C}_{\text {nose }}$ data with Shoulder width

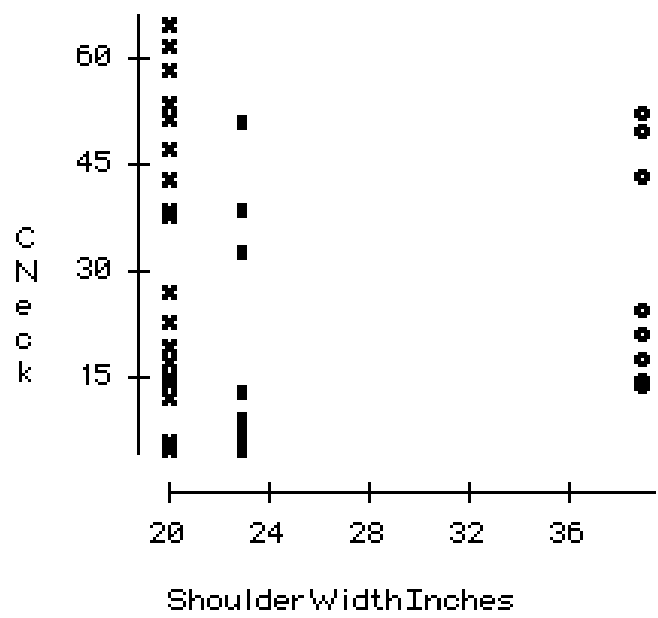

Figure Appendix 18.2: All $C_{\text {neck }}$ data with Shoulder width 


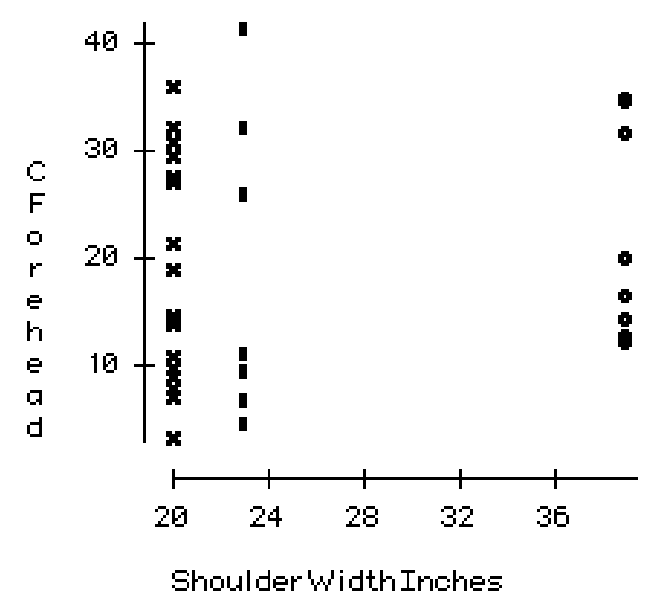

Figure Appendix 18.3: All $\mathrm{C}_{\text {forehead }}$ data with Shoulder width

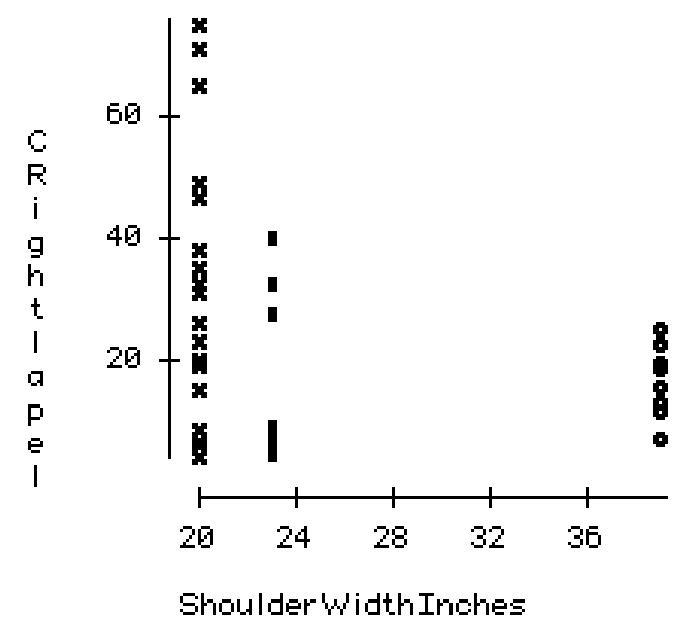

Figure Appendix 18.4: All $C_{\text {right lapel }}$ data with Shoulder width 


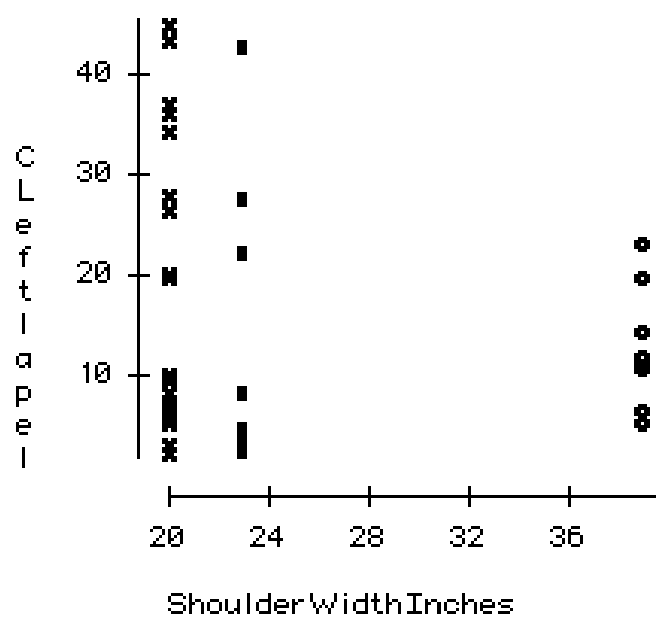

Figure Appendix 18.5: All $C_{\text {left lapel }}$ data with Shoulder width

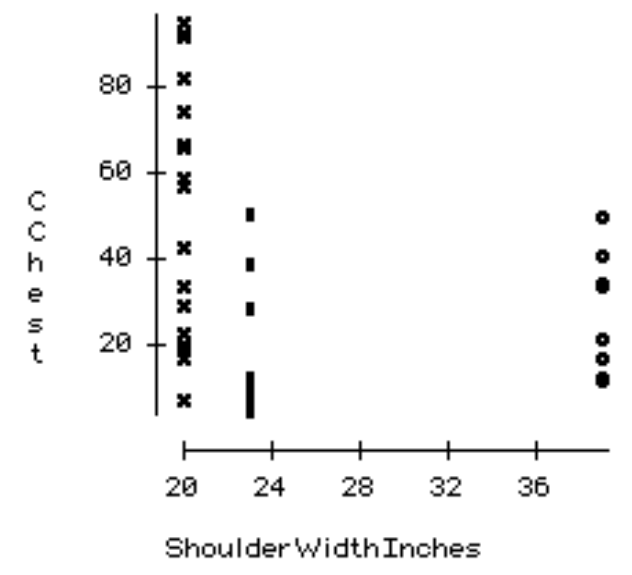

Figure Appendix 18.6: All $C_{\text {chest }}$ data with Shoulder width 


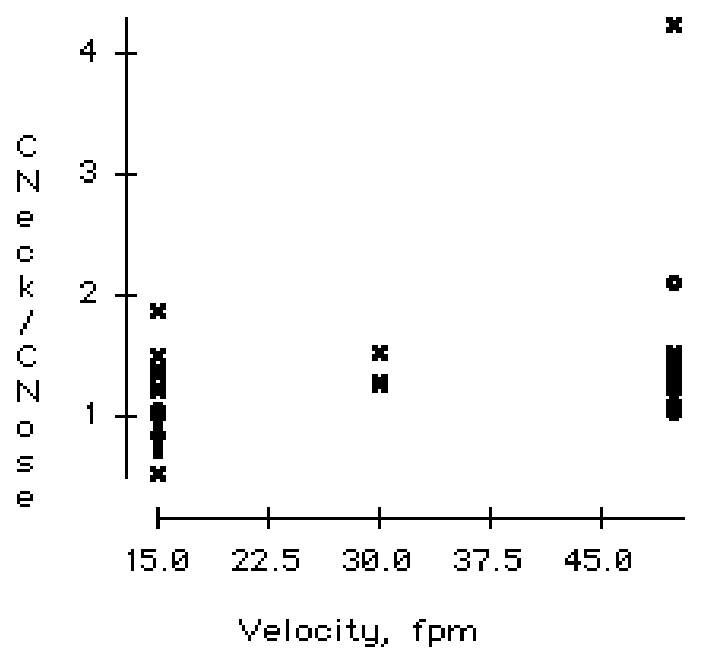

Figure Appendix 19.1: All $C_{n e c k /} C_{n o s e}$ with Velocity

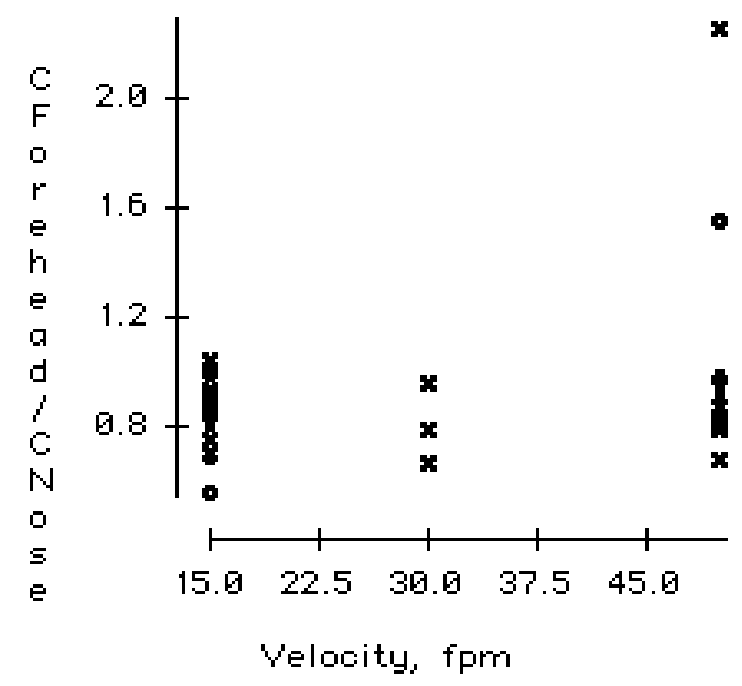

Figure Appendix 19.2: All $C_{\text {forehead } /} C_{\text {nose }}$ with Velocity 


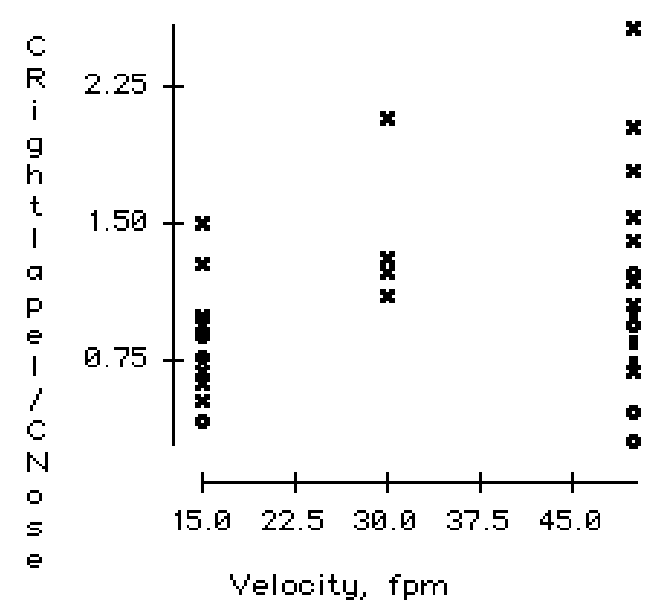

Figure Appendix 19.3: All $C_{\text {right lapel }} C_{\text {nose }}$ with Velocity

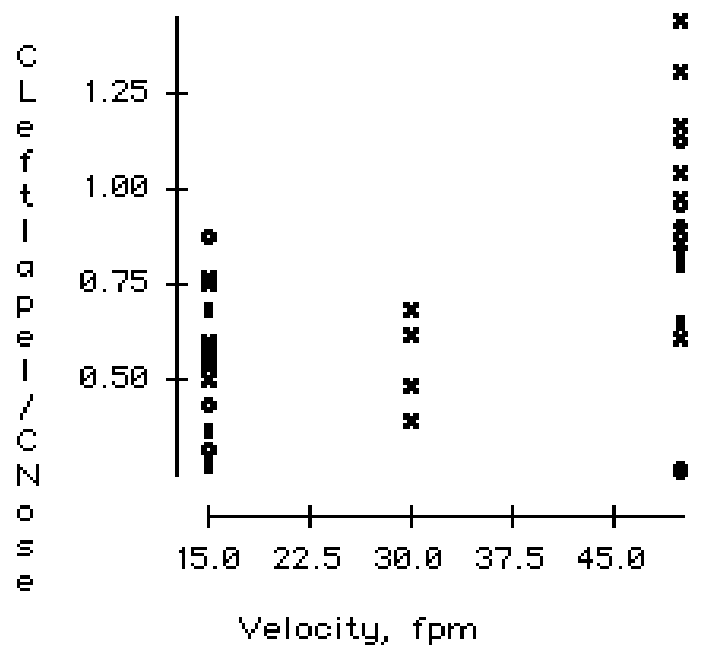

Figure Appendix 19.4: All $C_{\text {left lapel } / ~} C_{\text {nose }}$ with Velocity 


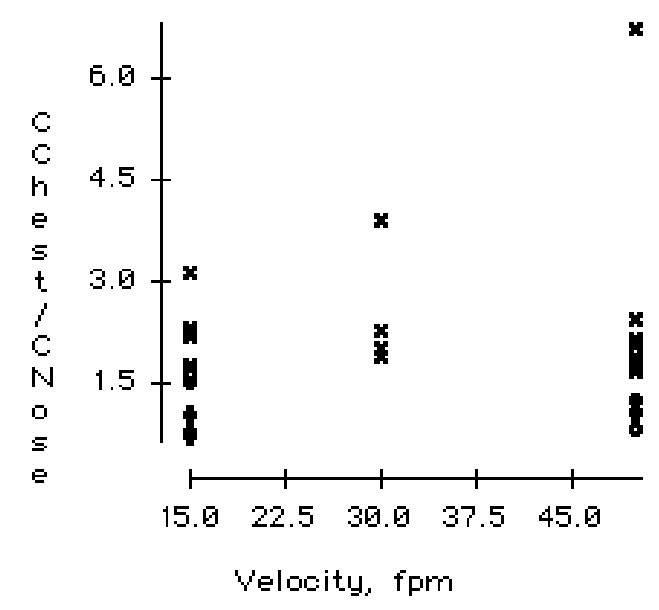

Figure Appendix 19.5: All $C_{\text {chest/ }} C_{\text {nose }}$ with Velocity

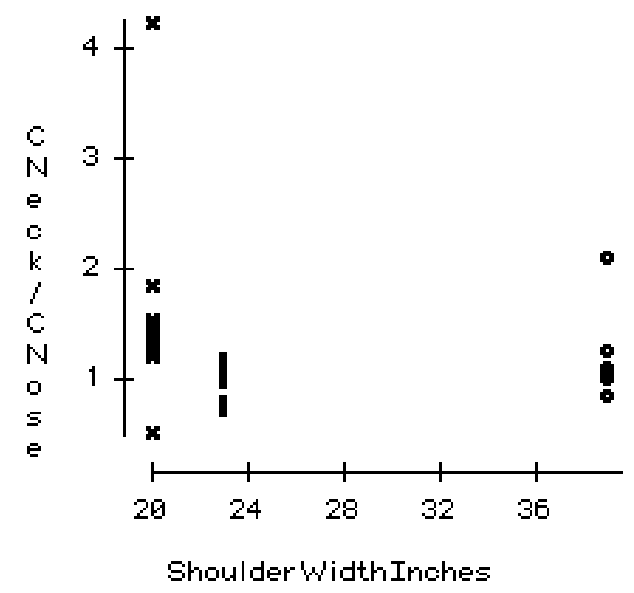

Figure Appendix 20.1: All $C_{\text {chest }} \mathbf{C}_{\text {nose }}$ with shoulder width 


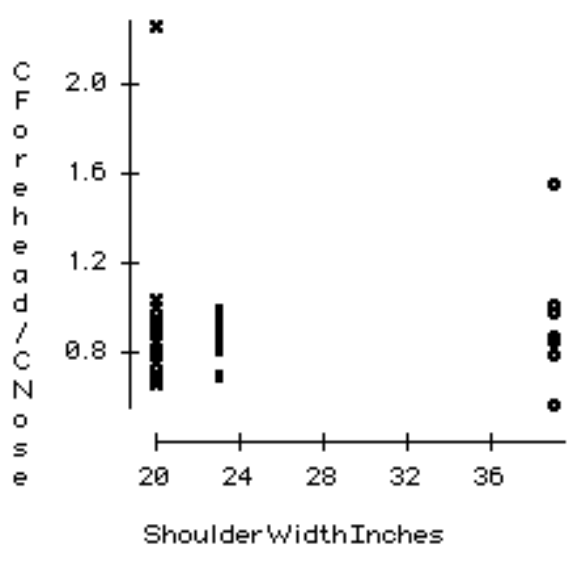

Figure Appendix 20.2: All $C_{\text {forehead } /} C_{\text {nose }}$ with shoulder width

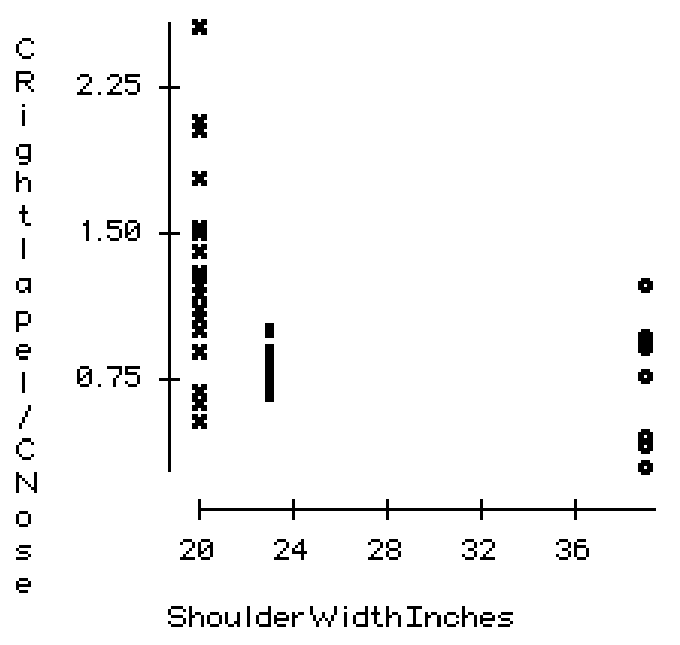

Figure Appendix 20.3: All $\mathrm{C}_{\text {right lapel }} / \mathrm{C}_{\text {nose }}$ with shoulder width 


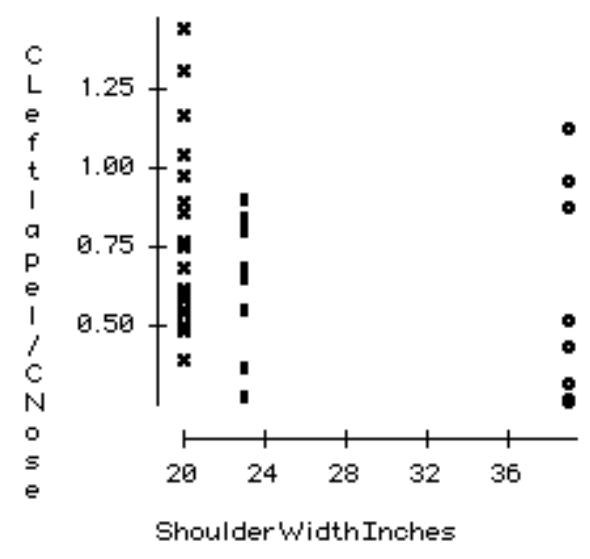

Figure Appendix 20.4: All $C_{\text {left lapel } /} C_{\text {nose }}$ with shoulder width

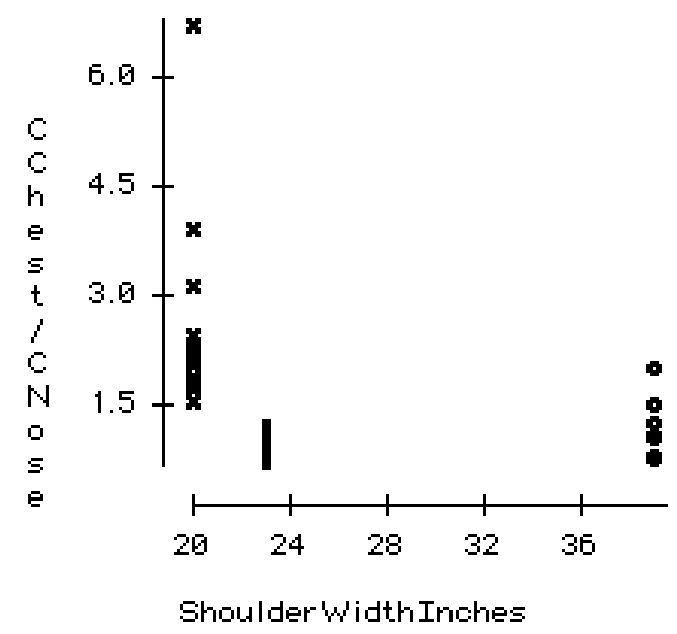

Figure Appendix 20.5: All $C_{\text {chest }} C_{\text {nose }}$ with shoulder width 


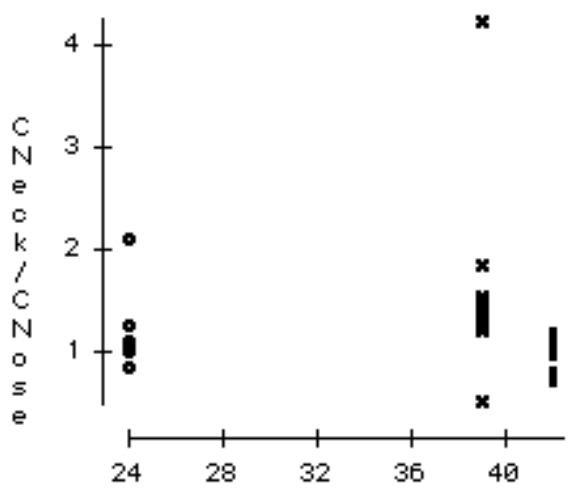

Chestcircumference(inches)

Figure Appendix 21.1: All $C_{n e c k} C_{\text {nose }}$ with chest circumference

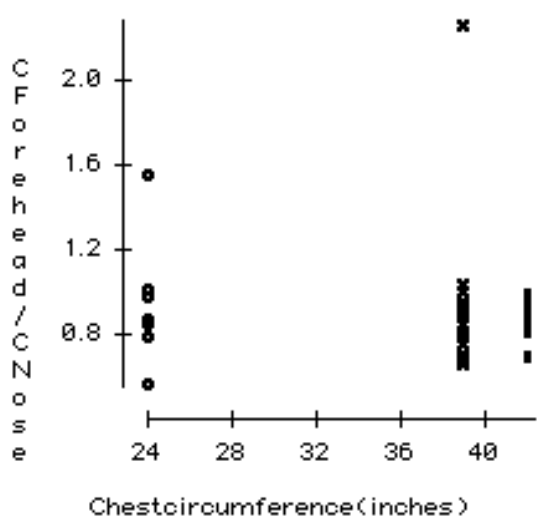

Figure Appendix 21.2: All $C_{\text {forehead/ }} C_{\text {nose }}$ with chest circumference 


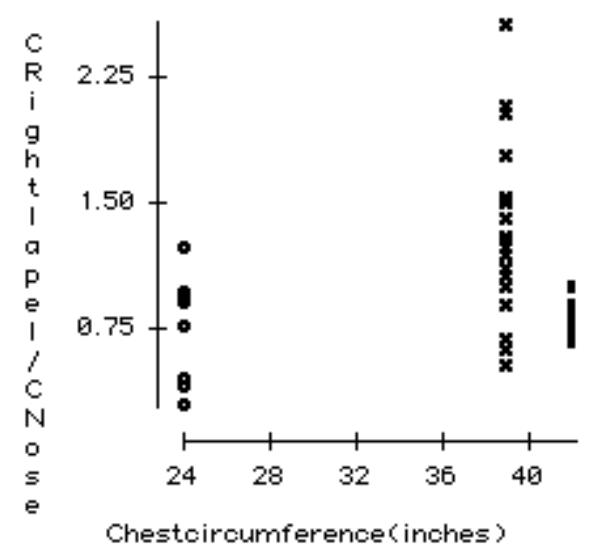

Figure Appendix 21.3: All $C_{\text {right lapel } /} C_{\text {nose }}$ with chest circumference

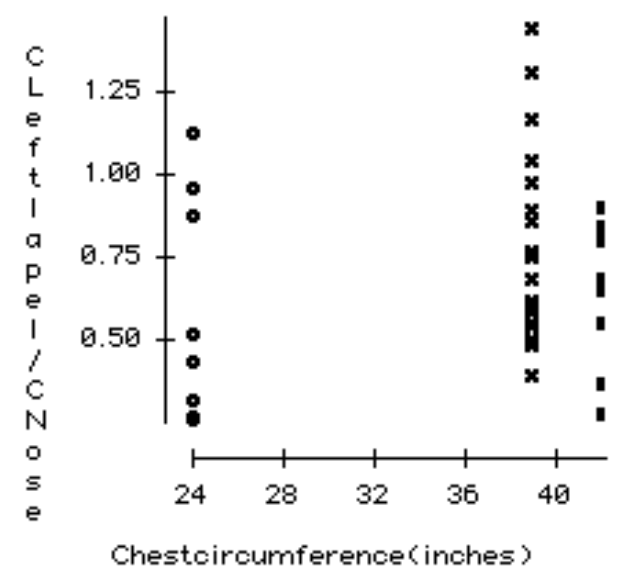

Figure Appendix 21.4: All $C_{\text {left lapel } /} C_{\text {nose }}$ with chest circumference

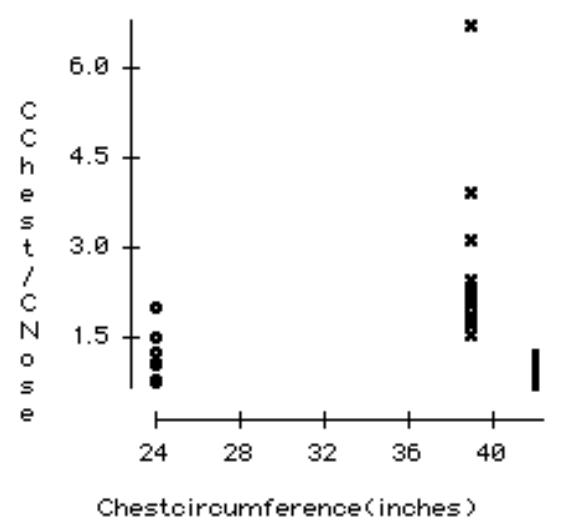

Figure Appendix 21.5: All $C_{\text {chest }} C_{\text {nose }}$ with chest circumference 